\title{
Case Study Field Evaluation of a Systems Approach to Retrofitting a Residential HVAC System
}

\author{
Iain Walker, Jennifer McWilliams and Steven Konopacki \\ Energy Performance of Buildings Group \\ Lawrence Berkeley National Laboratory \\ Berkeley, California 94720
}

September 2003

This work was supported by the Assistant Secretary for Energy Efficiency and Renewable Energy, Building Technologies Program, U. S. Department of Energy (DOE) under contract No. DE-AC03-76SF00098. 


\title{
DRAFT - DO NOT QUOTE
}

\begin{abstract}
This case study focusing on a residence in northern California was undertaken as a demonstration of the potential of a systems approach to HVAC retrofits. The systems approach means that other retrofits that can affect the HVAC system are also considered. For example, added building envelope insulation reduces building loads so that smaller capacity HVAC system can be used. Secondly, we wanted to examine the practical issues and interactions with contractors and code officials required to accomplish the systems approach because it represents a departure from current practice. We identified problems in the processes of communication and installation of the retrofit that led to compromises in the final energy efficiency of the HVAC system. These issues must be overcome in order for HVAC retrofits to deliver the increased performance that they promise. The experience gained in this case study was used to optimize best practices guidelines for contractors (Walker 2003) that include building diagnostics and checklists as tools to assist in ensuring the energy efficiency of "house as a system" HVAC retrofits. The best practices guidelines proved to be an excellent tool for evaluating the eight existing homes in this study, and we received positive feedback from many potential users who reviewed and used them. In addition, we were able to substantially improve the energy efficiency of the retrofitted case study house by adding envelope insulation, a more efficient furnace and air conditioner, an economizer and by reducing duct leakage.
\end{abstract}




\section{Table of Contents}

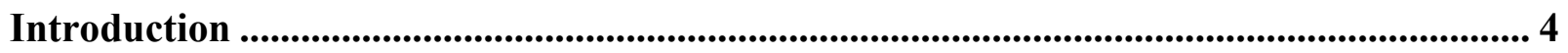

Diagnostics and Screening (D\&S) Process ............................................................ 5

Diagnostics and Screening Results from Four Houses........................................................ 14

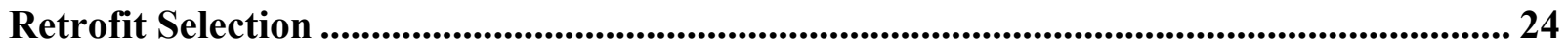

Diagnostics and Screening in Four Cold Climate Houses .............................................. 38

Lessons Learned for Best Practices Guidelines ................................................................... 39

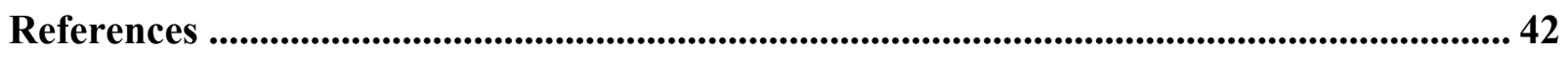

Appendix A. Field Surveys of Four Houses in California for Retrofitting ....................... 45

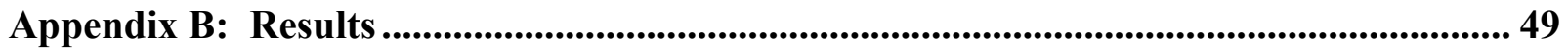

Appendix C. Calulation of Operating Energy Efficiency Ratio (EER) and Cooling Capacity ..........................................................................................................................62 62

Appendix D. Residential Commissioning Procedures.......................................................... 63

Appendix E: Schematic diagrams of the HVAC system ................................................69

Appendix F. Retrofit material and labor costs billed by the HVAC contractor. ............. 71

Appendix G. Field Surveys of Four Cold Climate Houses for Retrofitting ..................... 74 


\section{DRAFT - DO NOT QUOTE}

\section{Introduction}

The HVAC equipment installed in an energy efficient retrofit operates at the rated high efficiency only when the contractor performs an installation that adheres to strict standards. In this case study of a contracted residential HVAC energy efficient retrofit we describe our experiences of retrofitting a house with two contractors. We also describe the role of the local building code official. The retrofit utilizes a systems approach, which integrates many aspects of the building and Heating Ventilating and Air-Conditioning (HVAC) system to achieve improved performance compared to replacing individual components independently. This system-wide retrofit focuses on four areas of the building system: [1] building envelope sealing [2] additional attic floor insulation [3] duct sealing and additional duct insulation [4] down-sized highefficiency heating and cooling equipment. Because of the dry summer climate the retrofit included an economizer. Based on occupant complaints of severe stratification we added a zone control to allow better thermal control of the two floors of the house.

Rather than simply replace an HVAC system with equipment of the same energy efficiency, retrofits are an opportunity to use higher efficiency equipment. The HVAC system can have many added features that ensure increased comfort, safety and durability in addition to reduced energy use. Examples include: [A] multiple-speed heating or cooling equipment to better match building loads $[\mathrm{B}]$ added economizers to provide ventilation and reduce electricity consumption, and $[\mathrm{C}$ ] added zoning to increase comfort - this is particularly useful in houses that have large areas that are poorly conditioned. A classic example is the two-story house that currently operates as a single zone and does not provide enough cooling upstairs - a very common complaint.

The methodology to conduct the case study consisted of seven tasks: [1] pre-retrofit diagnostics to screen the building and HVAC systems of several homes to select a residence for the study [2] monitor the test residence over several months before and after the retrofit for energy and comfort performance [3] perform system-wide retrofits [4] post-retrofit diagnostics of the building and HVAC systems to measure improvement from retrofits [5] identify problems in the processes of communication and installation of the retrofit and evaluate quality of workmanship [6] propose solutions such that the HVAC equipment can provide energy efficient and comfortable cooling and heating for the occupants and apply these lessons to the best practices guidelines for contractors [7] develop guidelines and protocols for contractors.

To facilitate finding a house suitable for retrofit and obtaining timely homeowner permission to retrofit and monitor the house, we used a house volunteered and occupied by Lawrence Berkeley National Laboratory (LBNL) staff (homeowner acceptance of these types of retrofits and monitoring projects can be a barrier to obtaining access for use of a house). The retrofit combined readily available residential HVAC products into a system that can be regarded as an example and a basis for future work. The selection of components (e.g., equipment sizing) was based on an engineering analysis performed by LBNL combined with our previous experience in the field monitoring the performance of thermal distribution systems (Walker et al. 1999, Walker and Modera 1998, Walker et al 1998, Jump et al 1996, Jump and Modera 1994). 


\section{DRAFT - DO NOT QUOTE}

\section{Diagnostics and Screening (D\&S) Process}

A key aspect in the design of retrofits is the need to know the current performance of a house in order to understand which building components have the potential for improvement. To perform this task LBNL compiled a set of diagnostic screening tools that combine physical measurements, observations and a homeowner questionnaire. The measured test results, observations and homeowner answers to questions are used to direct the HVAC contractor or designer towards the best retrofits applicable to each individual house. The retrofits will depend on the current condition of the building envelope and HVAC system, the local climate, the construction methods used for the house, the presence of various energy reduction systems and/or materials, and issues that would allow particular energy saving systems (e.g., other retrofits or alterations to the house being performed at the same time as the HVAC retrofit). This approach is similar to a doctor referring a patient for blood tests or x-rays before actually performing surgery, where the doctor can diagnose the patient and be confident that he/she does the right thing. To take this analogy further - we can borrow from the medical profession and say that the first thought when retrofitting a house is to do no harm, i.e., do not make changes that could make the house worse to live in.

The checklist is not definitive and we expect that items will be removed, changed or added over time. For example, in our field testing we found that it was time consuming and requires someone with electrical training to determine the power consumption of all the individual elements of the HVAC system, so it is unlikely that this diagnostic would be part of an HVAC contractors toolkit - although for research level activities these tests provide vital information on system performance. Another example is the addition of pressure drop measurements across filters, where we found in one of our test houses that the homeowner had replaced the original poor filters with high efficiency MERV 12 filters. This change introduced considerable additional pressure drop in the system that the system had not been designed for. In this case we would recommend a retrofit that reduced flow resistance in the system (e.g., by replacing high resistance ducts or by adding return ducts) or replace the filters and filter rack with deeper element filters (i.e., 2 inch rather than one inch filters). These deeper filters offer the same filtration efficiency with increased surface area and therefore lower flow resistance.

The diagnostic screening tools are in checklist format and consist of three parts: [1] HVAC [2] envelope [3] and occupant survey. A template of the screening checklist is displayed in Table 1. This table includes a column for the actual value found during the D \& S process. The results of the diagnostics are discussed in the Diagnostics and Screening Results chapter. Detailed protocols for performing the diagnostics are presented in Appendix D. 
Table 1. Diagnostics Screening Checklist: HVAC, Envelope and Occupant Survey.

\begin{tabular}{|c|c|c|c|}
\hline $\begin{array}{l}\text { Measurement/Obser } \\
\text { vation }\end{array}$ & Potential Target value & $\begin{array}{l}\text { Actual } \\
\text { Value }\end{array}$ & Potential Retrofit Action \\
\hline Duct leakage & $<10 \%$ of air handler flow & & Seal ducts: Aeroseal/tape/mastic \\
\hline Duct insulation & $\begin{array}{l}\text { R6 (RSI 1) to R8 (RSI 1.4) for all ducts } \\
\text { outside conditioned space }\end{array}$ & & Add insulation to ducts \\
\hline Air flows at registers & Compare to ACCA manual J & & $\begin{array}{l}\text { Replace registers, open/close dampers, reduce system } \\
\text { flow resistance by straightening existing ducts or } \\
\text { replacing them with straight runs of new ducts. }\end{array}$ \\
\hline Air handler flow & $\begin{array}{l}\text { Cooling: }>400 \mathrm{cfm} / \text { ton in dry climate, } \\
\text { or }>350 \mathrm{cfm} / \mathrm{ton} \text { in humid climate } \\
\text { Heating: } 12.5 \mathrm{cfm} / \mathrm{kBtu} / \mathrm{h}\end{array}$ & & $\begin{array}{l}\text { Replace filters, fix duct restrictions, change fan speed, } \\
\text { replace fan with high efficient unit, add extra returns in } \\
\text { return restricted systems }\end{array}$ \\
\hline Filter Condition & Clean and at least MERV $6^{1}$ & & $\begin{array}{l}\text { Replace with MERV } 6 \text { or better. Use } 2 \text { or } 4 \text { inch filters } \\
\text { if possible }\end{array}$ \\
\hline Thermostat Setting & $\begin{array}{l}\text { Heating: } 68^{\circ} \mathrm{F}\left(20^{\circ} \mathrm{C}\right) \text { Cooling: } 78^{\circ} \mathrm{F} \\
\left(25^{\circ} \mathrm{C}\right)\end{array}$ & & $\begin{array}{l}\text { Thermostat raised in summer and lowered in winter to } \\
\text { account for better distribution, mixing and envelope } \\
\text { improvements. }\end{array}$ \\
\hline Spot ventilation & $\begin{array}{l}50 \mathrm{cfm} \text { each bathroom } \\
100 \mathrm{cfm} \text { each kitchen }\end{array}$ & & Replace fans, fix restrictive ducting \\
\hline $\begin{array}{l}\text { Spot Ventilation fan power } \\
\text { consumption }\end{array}$ & $\begin{array}{l}2.5 \mathrm{cfm} / \mathrm{W}(1.2 \mathrm{~L} / \mathrm{s} / \mathrm{W}) \text {. A good source } \\
\text { for these ratings is the HVI directory } \\
\text { (www.hvi.org) }\end{array}$ & & $\begin{array}{l}\text { Replace with higher efficiency unit, remove/reduce duct } \\
\text { flow restrictions, clean fan and ducting }\end{array}$ \\
\hline Equipment capacity & ACCA Manual S & & Replace with correct size \\
\hline Refrigerant charge & Use superheat or subcooling tests & & Add/subtract refrigerant \\
\hline $\begin{array}{l}\text { Age and Condition of HVAC } \\
\text { system }\end{array}$ & $\begin{array}{l}\text { Clean and undamaged. } \\
\text { Determine system age. }\end{array}$ & & $\begin{array}{l}\text { Clean the system and repair damage or Replace the } \\
\text { system if }>15 \text { years old }\end{array}$ \\
\hline $\begin{array}{l}\text { Location of HVAC system } \\
\text { equipment and ducts }\end{array}$ & Inside conditioned space & & $\begin{array}{l}\text { Seal and insulates duct locations to make them more like } \\
\text { conditioned space, or move system location. }\end{array}$ \\
\hline Window $\mathrm{A} / \mathrm{C}$ units & EnergyStar compliant & & Replace with central unit or improved distribution \\
\hline Multiple systems/zoning & $\begin{array}{l}\text { System and controls in good working } \\
\text { order and providing good comfort for } \\
\text { occupants }\end{array}$ & & $\begin{array}{l}\text { Ensure correct damper operation, check capacity of each } \\
\text { system/zone matches a Manual J (or equivalent) load } \\
\text { calculation }\end{array}$ \\
\hline Envelope leakage & $\begin{array}{l}\text { Normalized Leakage Area reduction of } \\
0.35\end{array}$ & & Insulate envelope, seal windows/doors/other openings \\
\hline Moisture testing & No moisture problems & & $\begin{array}{l}\text { Source control - better kitchen and bath venting, fix } \\
\text { flashing/detailing, seal and condition crawlspaces in } \\
\text { high humidity climates, replace windows, add insulation } \\
\text { to walls, floors and ceiling }\end{array}$ \\
\hline House insulation & $\begin{array}{l}\text { Ceiling: R-30 (RSI 5.3) minimum, R-49 } \\
\text { (RSI 8.6) in cold/severe cold climate. } \\
\text { Floor over crawlspace:R- } 25 \text { (RSI 4.4). } \\
\text { Basement walls: R10 (RSI 1.8), Basement } \\
\text { Floor or slab usually depends on local } \\
\text { codes. } \\
\text { Walls: Cavity should be completely filled } \\
\text { with insulation. }\end{array}$ & & $\begin{array}{l}\text { Add insulation to fill cavity. Add semi-permeable rigid } \\
\text { exterior insulation in cold/severe cold climates if the } \\
\text { wall is } 2 \times 4 \text { construction. }\end{array}$ \\
\hline Windows & $\begin{array}{ll}\begin{array}{l}\text { Double-glazed, low-e. } \\
\text { cooling dominant climates }\end{array} & \text { Shaded in } \\
\end{array}$ & & Replace windows. Add shading. \\
\hline Window shading & $\begin{array}{l}\text { Located on south and/or west facing } \\
\text { windows }\end{array}$ & & Add shading to reduce solar loads \\
\hline Solar radiation control & $\begin{array}{l}\text { Radiant barrier in attic, low absorptivity } \\
\text { roof coatings }\end{array}$ & & $\begin{array}{l}\text { Add radiant barrier in attic, or low absorptivity roof } \\
\text { coatings }\end{array}$ \\
\hline $\begin{array}{l}\text { Wall, floor and ceiling } \\
\text { construction }\end{array}$ & Space for ducts/vents & & \\
\hline \multicolumn{4}{|l|}{$\begin{array}{l}\text { Evaluate house energy bills (if } \\
\text { available) }\end{array}$} \\
\hline $\begin{array}{l}\text { Occupant survey } \\
\text { Ask occupants to report } \\
\text { problems }\end{array}$ & No problems & & $\begin{array}{l}\text { Moisture removal strategies, new windows (for } \\
\text { condensation resistance), change register type, airflow } \\
\text { and location to improve mixing/remove drafts, add } \\
\text { envelope insulation, etc. }\end{array}$ \\
\hline
\end{tabular}

${ }^{1}$ MERV is an industry standard rating system for air filters, it stands for Minimum Efficiency Report Value determined using ASHRAE Standard 52.2 


\section{DRAFT - DO NOT QUOTE}

\section{Duct Leakage}

An ideal duct system would have no duct leakage, however, the components, materials and installation techniques used for residential systems have led to most duct systems having significant leakage. Sealing these duct leaks is a key aspect of any HVAC retrofit because the energy savings can be significant (typically about 25-30\%). In addition, the system delivers more of its conditioned air to the conditioned space instead of losing it to the duct surroundings (usually attics, crawlspaces, garages or basements), which allows the use of reduced capacity equipment to meet the same building load. With current residential HVAC duct construction techniques, materials, and equipment it is very difficult to get to zero duct leakage. For this reason, recent specifications for duct leakage limits have allowed a small amount of leakage. For example, the Duct Efficiency Credit in the Alternative Calculations Manual procedure of the California State Energy Code (Title 24) (http://www.energy.ca.gov/title24/) allows duct air leakage at $25 \mathrm{~Pa}$ to be $6 \%$ of air handler flow for new construction. The US Environmental Protection Agency EnergyStar ducts page (http://www.energystar.gov/index.cfm?c=ducts.pr_ducts) sets a limit of $10 \%$ for duct leakage measured using the same technique as Title 24 (http://www.energystar.gov/ia/products/heat cool/ducts/Duct Spec 2002.pdf). An upper limit of $10 \%$ duct leakage is more appropriate when retrofitting existing systems as the $6 \%$ level is often difficult to reach.

There are several methods of duct leakage testing that have been developed for residential systems. In this study we used the most common method (duct pressurization) and a relatively new, more sophisticated method called DeltaQ. Both of these methods will be included in future versions of the ASTM standard for duct leakage E1554.

The Delta $Q$ (described in more detail in Walker et al. 2001 and Walker et al. 2002) test determines duct leakage flows by measuring the difference in flow through the house envelope when the house is maintained at a constant envelope pressure differential and the HVAC fan is turned off and on. The flows are measured at a number of different envelope pressure differentials, and then used to calculate duct leakage in the supply and return duct systems at operating conditions. Three major advantages of this test are: [1] it determines the air flow leakage to outside at operating conditions whereas tests such as duct pressurization determine the air flow leakage at a given pressure difference which may be quite different from the actual pressure difference that varies throughout the system [2] it does not require the sometimes difficult task of covering registers, and [3] in the course of performing this test, all the measurements are made for a multiple point fan pressurization test to determine envelope leakage so you get "two tests for the price of one".

The Duct Pressurization test is analogous to the fan pressurization test for envelope leakage. It measures the leakage through the ductwork at a fixed pressure induced by an external fan. The procedure involves sealing all the intentional openings in the ductwork (register grilles), and installing the external fan in an opening to the ductwork (usually in a return grille or at the air handler cabinet). If the supply and return leakage are desired separately then a blockage is placed between the supply and return side of the system (often in the filter slot). A single point or multi point test can be performed in the same manner as an envelope leakage test. Duct 


\section{DRAFT - DO NOT QUOTE}

leakage is often reported in $\mathrm{CFM}_{25}$, the flow at $25 \mathrm{~Pa}$ pressure differential across the duct boundary. The $25 \mathrm{~Pa}$ reference pressure is typical of an average pressure that the duct boundary might see in normal operation.

Ducts are often located in spaces that can be considered partly inside and partly outside of the thermal boundary such as spaces between the floors, or in wall cavities. In these spaces some of the losses from the ducts will be recovered into the living space through convection or conduction. In order to determine what fraction of leakage actually leaves the building, there is a variation of this test where the building envelope is pressurized to $25 \mathrm{~Pa}$ at the same time that the ductwork is pressurized to $25 \mathrm{~Pa}$. In this situation there will be no pressure difference between the ductwork and the inside space, therefore all the leakage measured will be between the ductwork and outside.

\section{Duct Insulation}

For flexible duct, the insulation level is often printed on the outer jacket. Otherwise insulation levels have to be estimated from the thickness and insulation type (for example glass fiber blanket and batt is approximately R-3.7 per inch). We recommend R-8 for ducts outside the conditioned space. R-8 ducts are rare and therefore most ducts will require additional insulation. The most common method is to apply a duct wrap of glass fiber insulation. Other alternatives include burying ducts in blown-in insulation - either restrained by cardboard forms or as part of additional envelope insulation (e.g., insulation added to attic floors when ducts are lying on the attic floor).

\section{Spot Ventilation}

Exhaust and supply fans in existing houses often have poor air flow due to bad installation (due to highly restrictive ducting) and accumulated dirt. These fans should be replaced with quiet, efficient fans that move the correct amount of air for their application - usually kitchen (100 $\mathrm{cfm})$ and bathroom $(50 \mathrm{cfm})$ venting. In some houses there may be more complex ventilation systems, such as Heat Recovery Ventilators (HRV), that are also prone to the same problems. Measuring the flows from these exhaust and supply fans can be accomplished using the same methods as used for airflows at registers. Another issue is to ensure correct routing of exhaust air. It is common to see exhaust fan ducts terminated inside attic spaces instead of going all the way through the roof. This condition is important in heating climates because the moist indoor air can condense on cold attic surfaces and lead to moisture problems. Kitchen range hoods tend to be vastly oversized in order to compensate for restrictive ductwork. This causes noisy fan operation, and can also cause a dangerous backdraft potential if there are natural draft combustion appliances located in the conditioned space. 


\section{DRAFT - DO NOT QUOTE}

\section{Air Flows at Registers}

Having the correct airflow at a register means that the HVAC system will be able to keep an individual room or area of the house comfortable. Target airflows should be based on engineering calculations using standard techniques such as those published by the Air Conditioning Contractors of America (ACCA) in their Manual J and Manual D. These targets should be combined with the results of discussions with the occupants. For example, if occupants complain about the heating or cooling of an individual room, then the airflow to the room needs to be investigated and changed. Measuring airflows at registers also allows us to identify possible disconnected ducts. Residential register airflow techniques range from the use of complex (but highly accurate) powered flow hoods, to simply timing how long it takes to fill a plastic bag. For system balancing, detecting disconnects or setting register flows, most of these techniques are acceptable (for a more thorough discussion of these measurement techniques see Walker and Wray 2003).

\section{Air Handler Flow}

Air handler flows need to be checked because systems with too low a flow $(<400 \mathrm{cfm} /$ ton of cooling in a dry climate, $<350 \mathrm{cfm} /$ ton of cooling in a humid climate or $<12.5 \mathrm{cfm} / \mathrm{kBtu} / \mathrm{h}$ of heating) tend to have poor efficiency for cooling or too high duct temperatures. In addition, for cooling operation, low air flow leads to icing of coils, and periodic failure of the system until the ice melts. Over time this often leads to premature failure of the compressor. For heating operation, the low air flows lead to excessive conduction loses, furnaces operating on high limit switches and dangerously hot furnaces and plenums. However for cooling systems in humid climates, the airflow may be set deliberately low in order to increase the latent capacity of the equipment. At the other end of the spectrum, systems with too high an airflow will tend to have noise problems and poor moisture removal in humid climates. Air handler flows should be measured using standard techniques such as pressure matching using an auxiliary fan and flowmeter or flow plates inserted into the system. (e.g., ASHRAE 152, California Title 24 and soon to be in ASTM E1554).

In this case study, we used the pressure matching technique, flow plates, and a research level test procedure that measures air handler airflow using the constant tracer gas injection method. This test involves injecting a known amount of tracer gas at the return grille, making sure that the return run is long enough to mix the tracer gas evenly into the air so that there is a uniform concentration of tracer gas within the duct, and (ideally) no tracer gas outside the zone. The tracer concentration is measured in a supply grille, and the flow is determined by calculating the volume flow of air necessary to create that concentration, with the known amount of gas injected.

\section{Filter Condition}

Filter condition is determined by visual inspection. ASHRAE Standard 62.2 recommends a minimum MERV rating of 6 for residential filters. These pleated filters are widely available in a one inch width, which allows them to fit into standard filter slots. 


\section{DRAFT - DO NOT QUOTE}

\section{Ventilation Fan Power Consumption}

Ventilation fan efficiency can be determined for many fans by visual inspection of the product label, and cross-referenced with published performance values. However, many older fans will not have published performance values and the only way to evaluate them is through diagnostic testing.

\section{Equipment Capacity}

Nameplate capacity of equipment is determined by visual inspection of the label. When performing retrofits, the correct equipment capacity should be determined using ACCA Manual J to determine the heating and cooling load of the house and Manual D to size the equipment and the ducts - including any improvements to the thermal envelope of the building such as increased ceiling insulation or better windows.

\section{Refrigerant Charge}

Refrigerant charge has an optimum level for efficiency and capacity. Both over and under charging reduces system performance, but undercharging is more common. In severe cases poor system charge can lead to equipment failure. Refrigerant charge can be estimated using standard industry test procedures: superheat or subcooling - depending on the manufacturers recommendations for an individual piece of equipment. One difficulty with these methods is that they cannot be performed in extremely dry weather or when it is cool. This restriction is primarily an issue when installing systems in winter months as it means the systems cannot be tested. When evaluating an existing system there are other indicators of charge problems - such as frozen indoor evaporator coils - that can be used as diagnostic tools. A refrigerant sight-glass can be used to visually monitor charge under various operating conditions. It is spliced into the liquid line at the inlet to the evaporator coil. If the $\mathrm{A} / \mathrm{C}$ is in steady-state operation and bubbles appear, the system is under-charged. Charge is then added slowly until the bubbles disappear and only liquid is visible.

The quantity of refrigerant charge in the system can be determined using the superheat method (Consortium for Energy Efficiency, 2000). Superheat refers to the temperature difference between the refrigerant leaving the evaporator coil and the saturation temperature of the refrigerant at that pressure. The superheat test can be used on fixed orifice or capillary expansion valve systems. It can only be used if the outdoor temperature and indoor temperatures are within a certain range. Generally, indoor temperature should be above 70 degrees $\mathrm{F}$ and outdoor temperature should be above 80 degrees F. If the superheat is too low it means that the refrigerant is in liquid form throughout too much of the evaporator tubing, indicating that the system is overcharged. If the superheat is too high it means that the refrigerant is changing into a gas too early and the system is undercharged. In order to do the test the suction line refrigerant pressure is measured and the saturation temperature calculated. Then the suction line refrigerant temperature is measured and the two are subtracted to find the superheat. The actual superheat must be compared to target superheat to determine if it is too high or too low. The target superheat is calculated for the given indoor and outdoor conditions by using a superheat chart provided by the air conditioner manufacturer. 


\section{DRAFT - DO NOT QUOTE}

The subcooling method is similar to the superheat method, but it uses the temperature difference between the refrigerant leaving the condenser and the condensing temperature of the refrigerant at that pressure to determine if the system is adequately charged. This method is used only for systems with thermostatic expansion valves (TXV). The superheat method doesn't work with TXV systems because the TXV controls the refrigerant flow such that the superheat remains constant (or within a range).

\section{Condition of HVAC system}

A simple evaluation of the age and visual appearance of the HVAC system can be a good indicator for repair or retrofitting. An older system will almost certainly have less efficient equipment than newer equipment and the degradation of air seals and flue systems with age present good candidates for retrofitting. A system that shows dirty, rusting sheet metal, missing duct tape, crushed fins, missing fasteners, dust marked open faced insulation, poor alignment of flues or air ducts, missing flues or air ducts, missing insulation, etc., is showing signs of neglect and is a good candidate for repair or retrofitting.

\section{Window AC Units}

Nameplate information is used to determine capacity and efficiency from manufacturer's information. The same observations of system degradation stated above are indicators for replacement.

\section{Multiple Systems/Zoning}

For zoning, the following questions should be answered: 1) Are there multiple heating/cooling systems in the house? Are they all the same age/condition - need to measure leakage/evaluate insulation separately. Are the ducts connected correctly? 3) Is the system zoned? Check thermostat locations and zonal separation. Check zone damper operation. Evaluate coil bypass/multi-capacity operation for zoning.

\section{Envelope Leakage}

Most houses in the US have leaky building envelopes that result in excessive air infiltration, uncomfortable drafts, and high energy bills. For many years weatherization programs have worked at sealing building envelopes to cure these problems. Sherman and Dickerhoff (1994) have compiled data from a large number of pressurization tests (over 10,000) in the United States, and have found the average normalized leakage to be 1.72 for single family dwellings. This study also showed an average reduction in Normalized Leakage $\left(\mathrm{NL}^{2}\right)$ of 0.35 due to weatherization. Buildings in the 70's and 80's were built tighter than earlier vintages, and some had indoor air problems due to inadequate ventilation air. Ventilation air can be supplied mechanically or naturally. ASHRAE Standard 62.2 sets the natural ventilation requirement at

\footnotetext{
${ }^{2} \mathrm{NL}$ is a method of accounting for the size of house in terms of its floor area and height when comparing envelope leakage between houses
} 


\section{DRAFT - DO NOT QUOTE}

$0.35 \mathrm{ACH}$ (on the order of $\mathrm{NL}=0.35$ ), and the mechanical ventilation limit at $15 \mathrm{cfm}$ per person plus $50 \mathrm{cfm}$ for each bathroom and $100 \mathrm{cfm}$ for the kitchen. See also ASHRAE standards (62.2, 119 and 136) and other codes like California State Energy Code (Title 24).

Envelope leakage is measured using standard pressurization techniques (e.g., ASTM E779, ASTM E1827, CGSB Standard 149.) The fan pressurization method involves closing all the doors and windows, setting up a large fan in an opening (usually a door) in the building shell. A pressure (usually between $20 \mathrm{~Pa}$ and $70 \mathrm{~Pa}$ ) is maintained across the building shell, and the flow through the fan is measured. ASTM E779-99 (1999) and E1827-95 (2000) give standardized procedures for these tests. Sometimes a single point test is performed, generally at $50 \mathrm{~Pa}$, or a multiple point test is performed over a range of induced pressures. If a multiple point test is performed, a curve of the form in equation 1 :

$Q=C(\Delta P)^{n}$

can be fit where $\mathrm{Q}$ is the flow through the fan and $\Delta \mathrm{P}$ is the pressure differential across the building shell. The parameters $\mathrm{C}$ and $\mathrm{n}$ are characteristic of the particular building being measured and are determined from the curve fit.

Often the leakage between various buildings is compared using $\mathrm{CFM}_{50}$, the leakage through the building shell at $50 \mathrm{~Pa}$. The information that would be more useful for energy use estimates is the flow across the building envelope at normal operating conditions. This flow is constantly changing since the pressure across the shell varies with weather conditions. To account for this, a parameter called Effective Leakage Area (ELA) was developed, which is the area of an orifice that provides the same flow as the building shell when subjected to a reference pressure differential. The pressure differential that is commonly used in the US is $4 \mathrm{~Pa}$ because it is typical of the pressure that building envelopes experience.

ASTM method E779-99 (1999) outlines how to determine building envelope leakage area (including the calculation for ELA) using fan pressurization. Although fan pressurization does not give a measurement of actual ventilation during normal building operation, it is a useful test in order to compare the leakage area of two different buildings, to assist in identifying leakage sources, and to determine the leakage reduction from an individual retrofit.

\section{Ceiling, Wall and Floor Insulation}

Envelope insulation needs to be estimated from observation of insulation type and thickness. In retrofit cases walls can be insulated with blown in insulation if the existing stud cavity is empty. Attics can be insulated with blown insulation that covers the joists to minimize thermal bridging, and basements and crawlspaces can be insulated with fiberglass batts. There are some areas that are unpractical to insulate in a retrofit situation such as under a slab on grade, or in wall cavities that are already partially insulated. 


\section{DRAFT - DO NOT QUOTE}

\section{Windows and Window Shading}

Because windows contribute significantly to the thermal load for houses this information is required so that reasonable building load and equipment sizing calculations can be made. In addition, a retrofit that includes added shading to south or west-facing windows in sunny cooling dominated climates requires an estimate of window size and location. Window type is a good indicator of the retrofit potential for the windows. Single-pane aluminum-frame windows have poor thermal performance (and have high condensation potential) and are good candidates for replacement whereas double pane vinyl-frame windows would not need to be replaced. Simple observation of frames looking for signs of moisture damage will give valuable information regarding not only window performance and likelihood of replacement - but also of high humidity conditions in the house or the presence of water leaks in around the window openings. Window retrofits are generally not justified in a retrofit program due to the large expense and long payback time, however, window retrofits are often undertaken by home owners for other reasons such as condensation resistance or aesthetics. Therefore there can be an opportunity to combine energy efficiency gains from window changes together with changes in the HVAC system.

\section{Solar Radiation Control}

The presence of radiant barriers, sunshades, or solar-reflective roofs means that these items (if in good condition) that would normally be part of a retrofit do not need to be considered. Solarreflective roofing materials are commercially available for sloped-roof applications (white asphalt shingles and colorful ceramic tiles) and for low-sloped or flat roofs (white acrylic, elastomeric and cementitious coatings, and white, gray and blue thermoplastic membranes). Refer to the LBNL Heat Island Group's Cool Roofing Materials Database at http://eetd.lbl.gov/CoolRoofs/ and the EPA Energy Star ${ }^{\circledR}$ for Roof Products Qualifying Products

List at http://yosemitel.epa.gov/estar/consumers.nsf/content/roofbus.htm. We do not recommend painting or coating a conventional asphalt shingle roof white. The numerous seams in the asphalt shingle roof make it possible for water to accumulate under the shingle edges, particularly in humid climates. With a dark-colored shingle roof, water that has accumulated evaporates the next time the shingle heats up. With a white-coated roof, the shingles tend not to heat up enough to fuel water vaporization - leading to potential moisture damage.

\section{Ceiling, Wall and Floor Construction}

The type of wood or steel framing or the use of other materials restricts the places that HVAC ducting or plumbing can be run.

\section{Moisture}

Visually inspect for signs of moisture such as wetness, mold, mildew, variations in color and texture, and dimensional/structural problems. Note that visual observation is only good for existing problems in visible surfaces and cannot evaluate the potential for future problems, problems buried within the construction of the home. Also, be aware of any special odors associated with moisture. Electrical inspection by impedance scanning and conductance probing 


\section{DRAFT - DO NOT QUOTE}

can be used to detect subsurface problems before they are visually apparent. One of the objectives of the retrofit packages is to have HVAC systems that are effective at controlling moisture and do not increase the potential moisture problems for the building envelope.

\section{Occupant Survey}

Ask occupants to report problems (comfort. high bills, condensation, mold, etc.) and ask about important lifestyle activities that can significantly change building loads and the times that the house needs to be conditioned. The following are some typical questions that might be asked:

- How many people live in the house? More occupants indicate that the chances for humidity and other Indoor Environmental Quality (IEQ) problems will be greater (therefore a tight house envelope will require the addition of mechanical ventilation).

- Are there any pets? Like human occupants pets are a source of moisture and odors. This means that adequate ventilation is required - with more ventilation required for more or larger pets. Fish-tanks are a source of humidity - particularly if they are large and/or uncovered. Exotic pets may have particular temperature and humidity requirements that make for unusual building loads - check with the homeowner. Pets may also restrict the use of setback or setup programmable thermostats.

- High Energy Bills? High energy bills can be a good indicator of HVAC system problems, and the potential to perform envelope upgrades makes more financial sense if there is the potential to save a lot of money.

\section{Diagnostics and Screening Results from Four Houses}

Four houses in a mixed-dry or hot-dry climate within 50 miles of the San Francisco Bay were surveyed using the diagnostic screening approach (Table 1) and one was selected for retrofit. Our objective was to select the house with the greatest potential for improvement from the retrofits. The four houses will be referred to by location: Concord, Moraga, Castro Valley and Larkspur. The key screening results for the four residences are shown in Table 2. More details of the screening results can be found in the tables of Appendix A. 
DRAFT - DO NOT QUOTE

Table 2. Comparison of Initial Screening Results of the Four Residences.

\begin{tabular}{|c|c|c|c|c|c|}
\hline Diagnostic & Units & Concord & Moraga & Castro Valley & Larkspur \\
\hline $\begin{array}{l}\text { duct leakage at } \\
\text { operating - supply }\end{array}$ & $\mathrm{L} / \mathrm{s}(\mathrm{cfm})$ & $15(48)$ & $111(365)$ & $33(109)$ & $37(122)$ \\
\hline $\begin{array}{l}\text { duct leakage at } \\
\text { operating - return }\end{array}$ & $\mathrm{L} / \mathrm{s}(\mathrm{cfm})$ & $100(328)$ & $92(302)$ & $16(54)$ & $63(207)$ \\
\hline $\begin{array}{l}\text { duct leakage at } \\
\text { operating - } \\
\text { supply }\end{array}$ & & $6 \%$ & $22 \%$ & $9 \%$ & $10 \%$ \\
\hline $\begin{array}{l}\text { duct leakage at } \\
\text { operating - return }\end{array}$ & & $41 \%$ & $18 \%$ & $5 \%$ & $17 \%$ \\
\hline $\begin{array}{l}\text { air flows at } \\
\text { registers (sum } \\
\text { supply) }\end{array}$ & $\mathrm{L} / \mathrm{s}(\mathrm{cfm})$ & $238(779)$ & $380(1246)$ & $251(823)$ & $342(1120)$ \\
\hline $\begin{array}{l}\text { air flows at } \\
\text { registers (sum } \\
\text { return) }\end{array}$ & $\mathrm{L} / \mathrm{s}(\mathrm{cfm})$ & $133(435)$ & 433 (1419) & $290(980)$ & $\mathrm{n} / \mathrm{a}$ \\
\hline $\begin{array}{l}\text { air handler fan } \\
\text { flow (cooling } \\
\text { mode) }\end{array}$ & $\mathrm{L} / \mathrm{s}(\mathrm{cfm})$ & $245(804)$ & $502(1646)$ & 353 (1159) & $371(1216)$ \\
\hline $\begin{array}{l}\text { superheat test } \\
\text { (difference from } \\
\text { target superheat) }\end{array}$ & ${ }^{\circ} \mathrm{C}\left({ }^{\circ} \mathrm{F}\right)$ & $8.9(16)$ & $-7(-12.7)$ & $7(12.6)$ & $0(0)$ \\
\hline refrigerant charge & & $\begin{array}{c}\text { undercharge } \\
\mathrm{d}\end{array}$ & overcharged & undercharged & correct charge \\
\hline $\begin{array}{l}\text { measured } \\
\text { equipment } \\
\text { capacity }\end{array}$ & $\mathrm{W}(\mathrm{btu} / \mathrm{h})$ & $8089(27600)$ & $\mathrm{n} / \mathrm{a}$ & $\mathrm{n} / \mathrm{a}$ & $9847(33600)$ \\
\hline heat load Man. J & W (btu/h) & $\begin{array}{c}28,741 \\
(98,070)\end{array}$ & $\begin{array}{c}21,951 \\
(74,900)\end{array}$ & $\begin{array}{c}12,690 \\
(43,300)\end{array}$ & $\mathrm{n} / \mathrm{a}$ \\
\hline cool load Man. J & $\mathrm{W}(\mathrm{btu} / \mathrm{h})$ & $\begin{array}{c}12,305 \\
(41,985)\end{array}$ & $\begin{array}{c}17,203 \\
(58,700)\end{array}$ & $8,675(29,600)$ & $\mathrm{n} / \mathrm{a}$ \\
\hline $\begin{array}{l}\text { rated capacity of } \\
\text { existing cooling } \\
\text { equipment }\end{array}$ & $\mathrm{W}(\mathrm{btu} / \mathrm{h})$ & $\begin{array}{c}11,606 \\
(39,600)\end{array}$ & $\begin{array}{c}22,859 \\
(78,000)\end{array}$ & $\begin{array}{c}12,749 \\
(43,500)\end{array}$ & $\begin{array}{c}10,551 \\
(36,000)\end{array}$ \\
\hline $\begin{array}{l}\text { system oversize } \\
\text { ratio }\end{array}$ & & 0.94 & 1.33 & 1.47 & $\mathrm{n} / \mathrm{a}$ \\
\hline envelope leakage & $\mathrm{m}^{2}\left(\mathrm{in}^{2}\right)$ & $0.179(278)$ & $0.229(355)$ & $0.174(269)$ & $0.219(340)$ \\
\hline ceiling insulation & $\mathrm{R}$ & 26 & 17 & 25 & inaccessible \\
\hline
\end{tabular}

The Castro Valley house was eliminated because the building shell and ducts were the tightest of the four houses. It was a difficult choice between the remaining three houses. They all had 


\section{DRAFT - DO NOT QUOTE}

leaky building shells, and leaky duct systems. The Moraga house was complicated by the fact that there were two HVAC systems. One of the HVAC systems was 15 years old and leaky, and the second was newer (only 7 years old) and had very little leakage. Both systems were slightly overcharged. The Larkspur house had a leaky shell and leaky ducts, but it had a condensing furnace with 3 ton air conditioner, which performed almost at the rated 3 tons $(2.8$ tons on the day that we tested it). The shell leakage would be impossible to fix at this house since the ceilings were all tongue and groove boards, which are difficult to seal without changing the desired appearance.

The Concord house was selected for the case study because it showed the greatest potential for improvements. The house was a 27-year old single-family two-story dwelling of approximately $2500 \mathrm{ft}^{2}$ with attached garage, and was cooled and heated by it's original central gas furnace/airconditioning system located in the garage, with ducts primarily located in the attic and garage. The roof was constructed with colored ceramic tiles on a sloped plywood deck, over a naturally ventilated and unconditioned attic, with fiberglass insulation (R-26) between the 2 by 8 joists on 16" centers. A floor plan of the test residence with existing ducts is shown in Figure 1 and exterior views are displayed in Figure 2.

The house had the following combination of problems: low-efficiency heating and cooling equipment (Figures 3 and 4), leaky and poorly insulated ducts (Figure 5), and a leaky exterior envelope (also in Figure 5). In addition, the air handler, furnace, cooling coils and most of the duct system were located outside the conditioned space in the garage and attic. A few major components of the shell leakage were easily identified in this house: several large mechanical chases that were open to the attic, as well as a building cavity return that was open to the garage and the attic. The HVAC system was undercharged and operating at only $2 / 3$ of its rated capacity. We suspected that the refrigerant line had a leak due to the low charge in the system. Also, the homeowner reported problems in cooling the upstairs of the house. 
DRAFT - DO NOT QUOTE
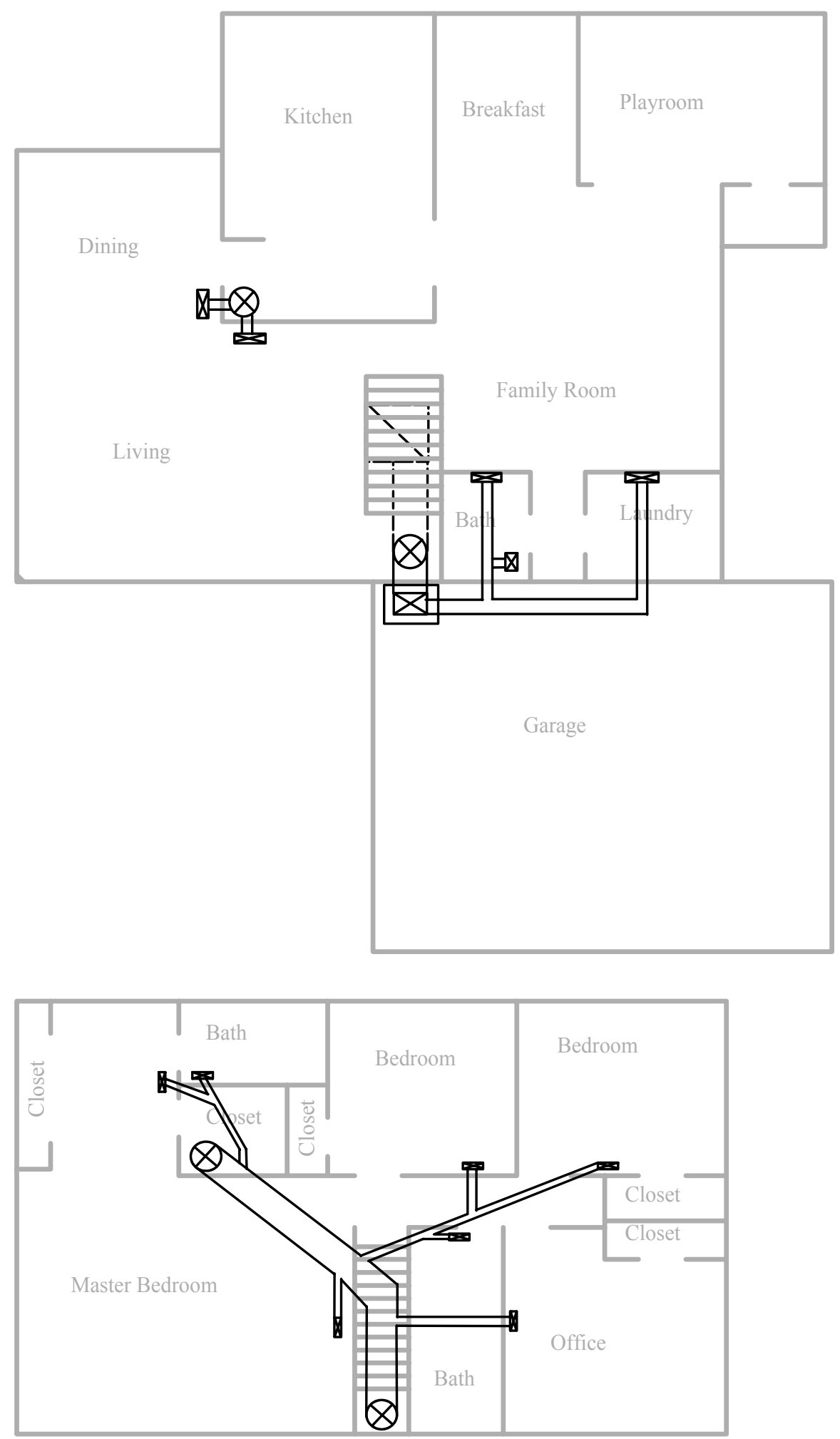

Legend 디 return $\bigotimes$ supply

Figure 1. Floor plan of case study residence with existing ducts. Upper level on top. 


\section{DRAFT - DO NOT QUOTE}

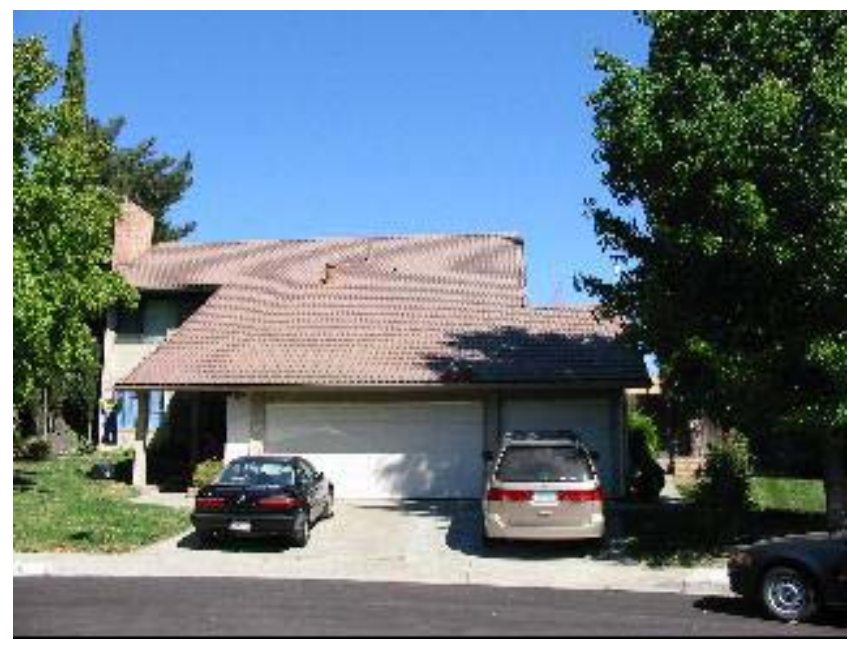

Figure 2(a). Exterior front view of Concord test residence.

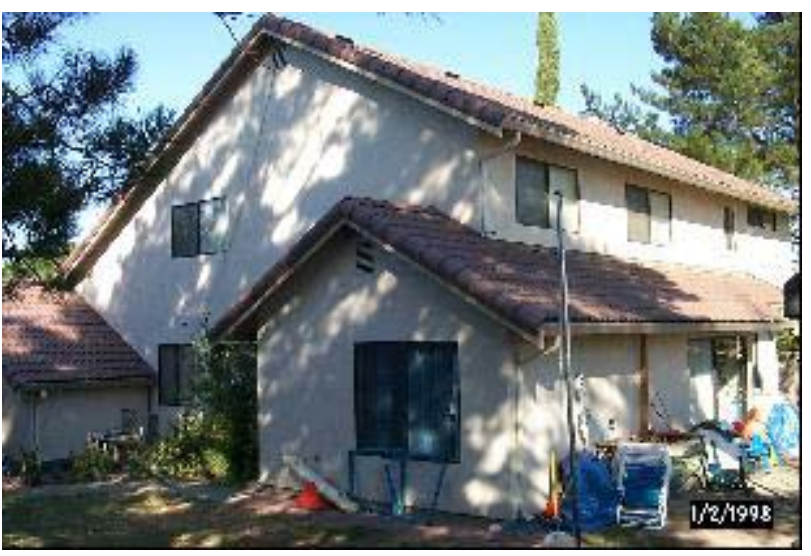

Figure 2(b). Exterior side view of Concord test residence showing gable attic vents and existing outside $\mathrm{AC}$ condenser unit placement [lower left].

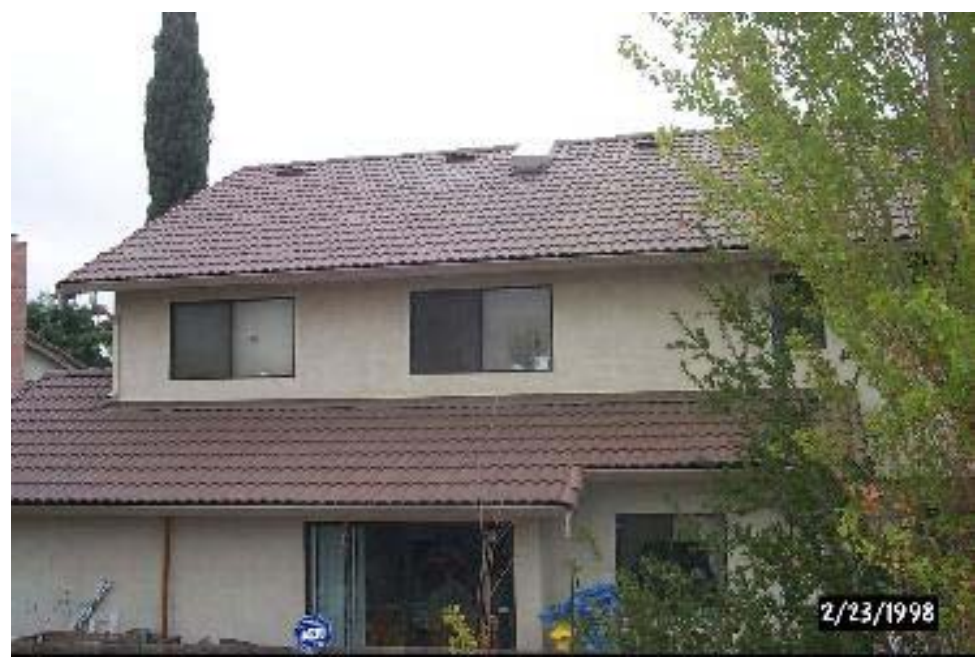

Figure 2(c). Exterior rear view of Concord test residence. 

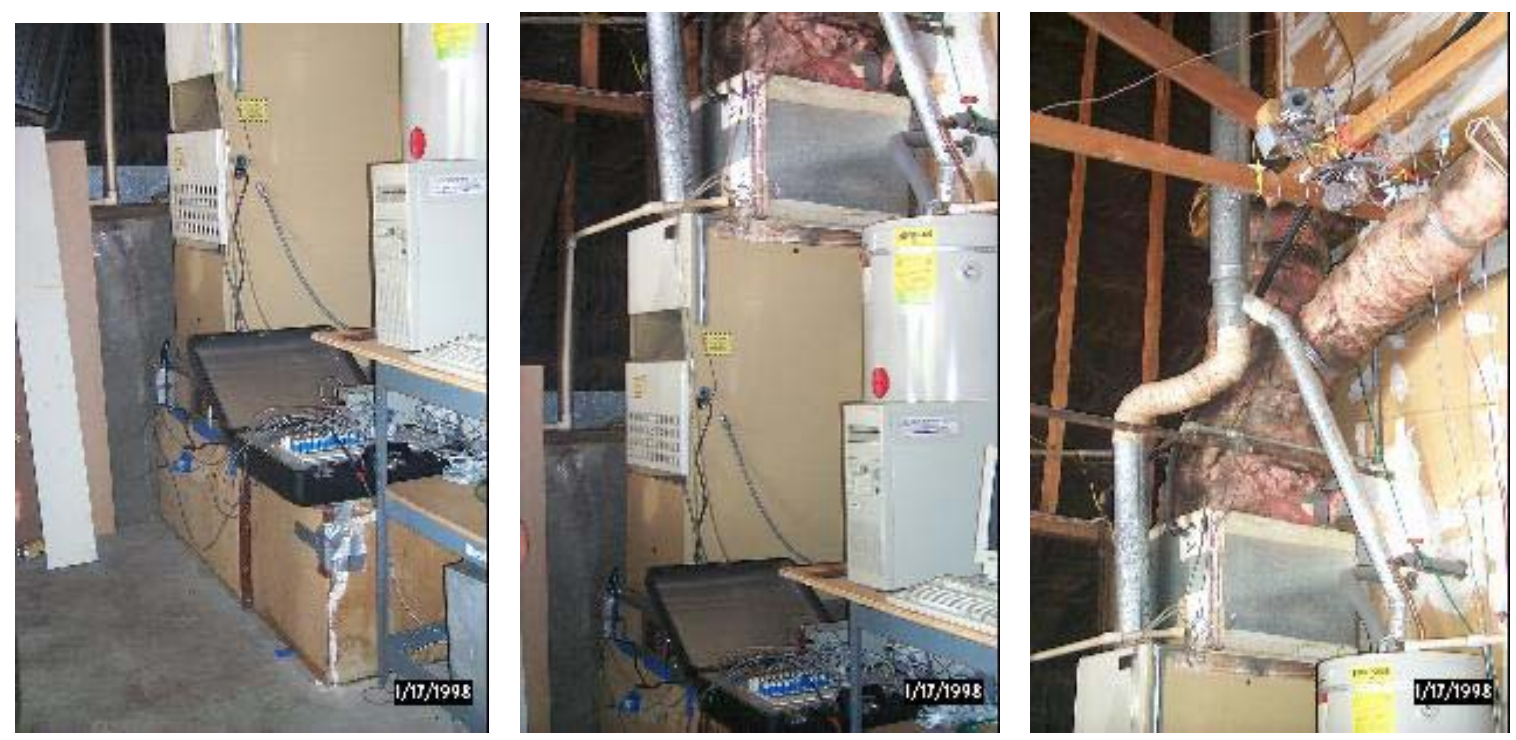

Figure 3. Existing HVAC equipment in garage [left to right: return plenum, air handler, furnace, cooling coil and supply ducts].
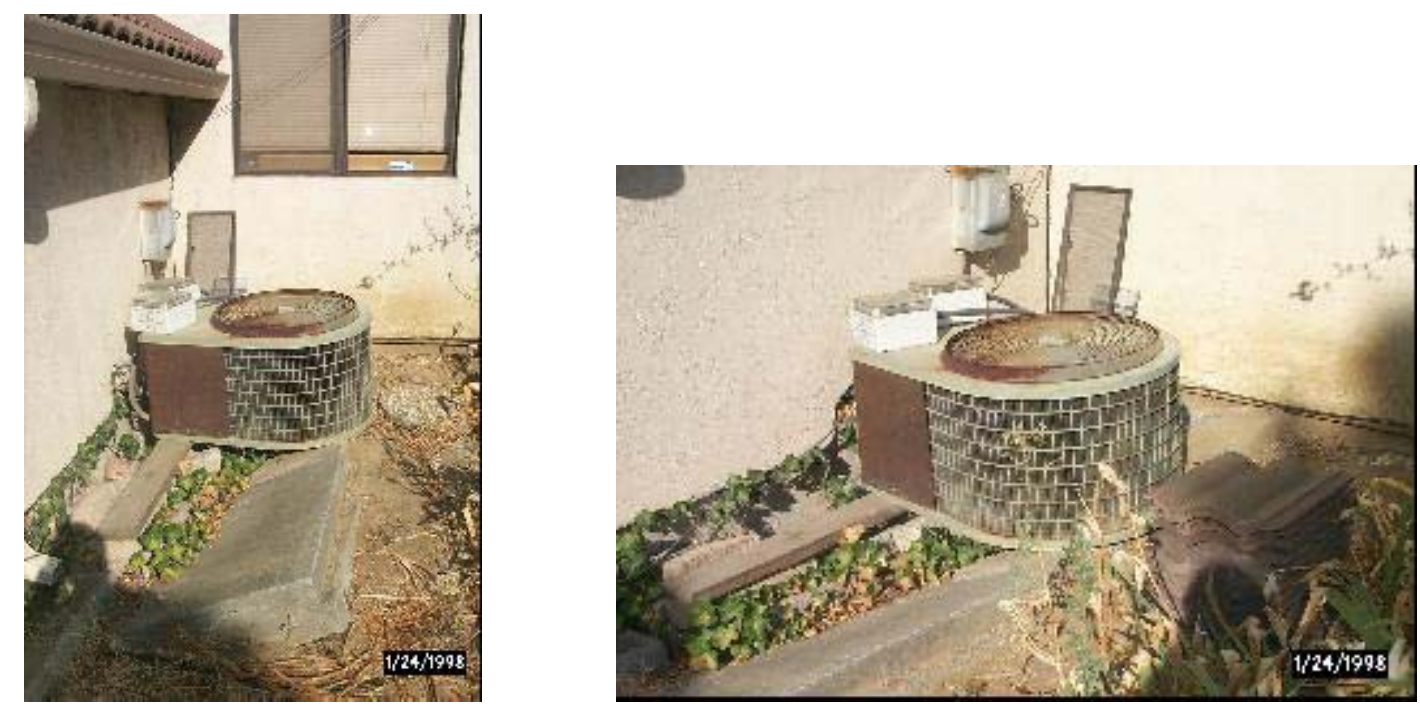

Figure 4. Existing AC condensing unit outside near rear of garage showing poor condition of unit [heavily corroded sheet metal fasteners and significant dirt/dust accumulation blocking flow into coil] and subsided slab [stressed refrigerant tubing and subsequent leakage of refrigerant]. 


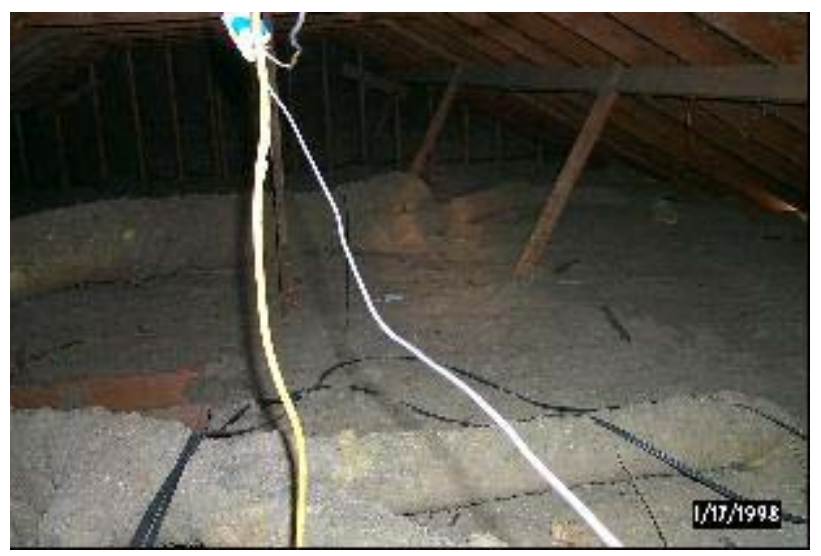

Figure 5(a). Existing attic floor showing insulated metal ducts and insulation coverage.
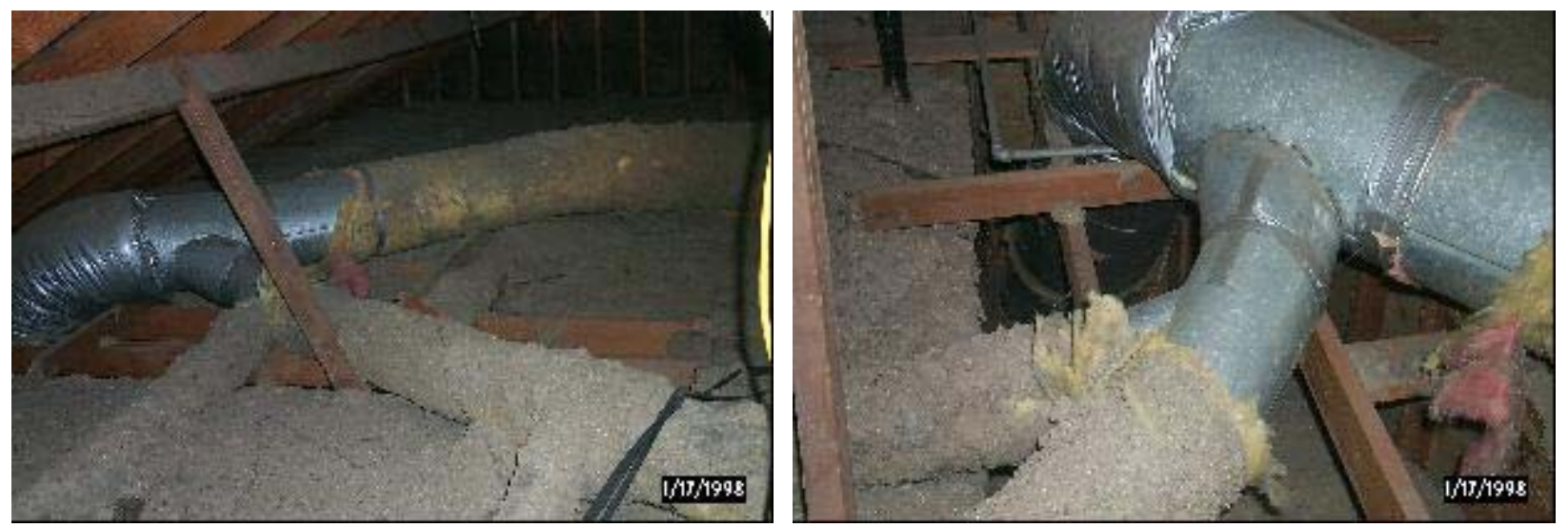

Figure 5(c). Existing supply duct run from garage to attic showing large openings in attic floor plane [above stairway dropped ceiling].

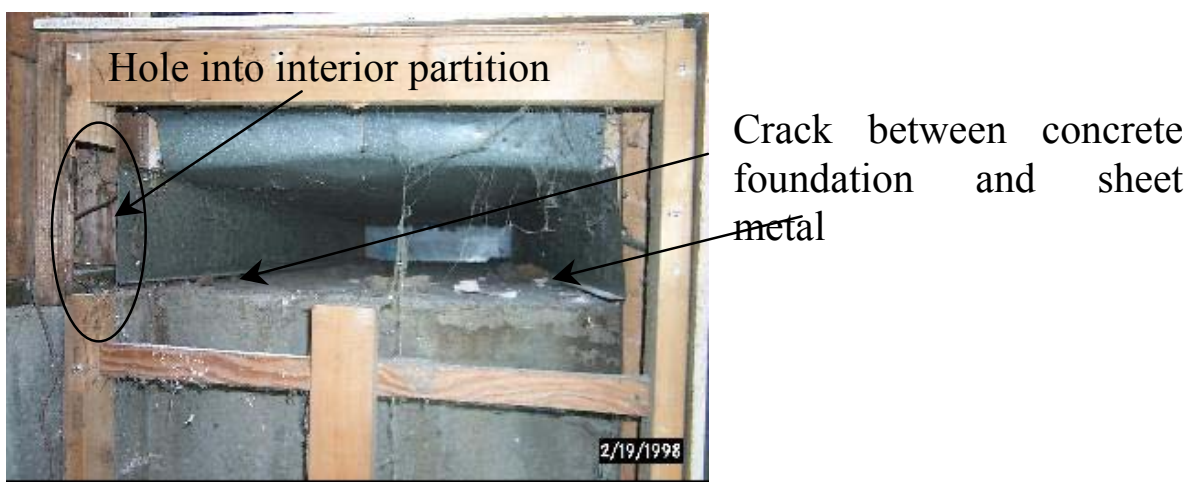

Figure 5(d). Existing return cavity between foundation and lower level floor. 


\section{Key Screening Results: Case Study Residence}

The key screening results and occupant issues for the Concord test residence are listed below and the pre- and post-retrofit diagnostics are shown in Table 3.

1. Leaky envelope (10 $\mathrm{ACH}_{50}$ equivalent to an $\mathrm{NL}$ of 0.9$)$.

2. Dirty and leaky ducts $-48 \mathrm{cfm}$ supply and $328 \mathrm{cfm}$ return (47\% of air handler flow supply and return combined.

3. Low air handler flow only $800 \mathrm{cfm}$ (rather than the $1400 \mathrm{cfm}$ expected for a $400 \mathrm{cfm} / \mathrm{ton}, 3.5$ ton nominal system ${ }^{3}$ ).

4. Refrigerant charge $25 \%$ low.

5. Dirty condenser cooling coil with crushed fins.

6. Building in hot-dry moderate climate.

7. Building, furnace/air handler/ac are $>25$ years old.

8. System is easily accessible in garage.

9. Wall cavity ducts are inaccessible between floors.

10. Poor air distribution with not enough cooling upstairs.

11. Ineffective and/or non-operative electrostatic air filter.

12. Condenser unit is corroded.

13. Condenser unit is poorly sited in sun and on subsided concrete pad.

14. New (installed in 1998) ceramic tile roof in excellent condition.

15. Insulated walls.

16. Single pane windows with aluminum frame.

Occupant Issues:

1. Reported distribution of cooling is not adequate: upstairs is hotter than downstairs when cooling.

2. Occupants have sensitivity to airborne particles - so the HVAC system requires good filtration.

\footnotetext{
${ }^{3}$ With the low air conditioning capacity (mostly due to undercharge) the low air handler flow is less of a problem, because the target air handler flow would be only $900 \mathrm{cfm}$ (for the 2.3 ton measured capacity). This condition shows how coincident problems can mask each other. These two problems result in poor HVAC efficiency, but will not show up as system problems such as frozen coils or failed compressor.
} 
Table 3. Diagnostics Summary Sheet of Pre- and Post-Retrofit Comparison at the Test Residence.

\begin{tabular}{|l|l|l|l|}
\hline Diagnostic & Units & Pre & Post \\
\hline duct leakage at operating - supply & cfm & 48 & n/a \\
\hline duct leakage at operating - return & cfm & 328 & n/a \\
\hline duct leakage at operating - supply & & $6 \%$ & n/a \\
\hline duct leakage at operating - return & & $41 \%$ & n/a \\
\hline duct leakage at 25 Pa - supply & cfm & 86 & 60 \\
\hline duct leakage at 25 Pa - return & cfm & 786 & 136 \\
\hline duct leakage at 25 Pa - supply & & $11 \%$ & $4 \%$ \\
\hline duct leakage at 25 Pa - return & & $98 \%$ & $9 \%$ \\
\hline air flows at registers (sum supply) & cfm & 779 & 1458 \\
\hline air flows at registers (sum return) & cfm & 435 & n/a \\
\hline $\begin{array}{l}\text { air handler fan flow (cooling } \\
\text { mode) }\end{array}$ & cfm & 804 & 1525 \\
\hline refrigerant charge & & undercharged & correct charge \\
\hline measured equipment capacity & btuh & 27600 & n/a \\
\hline heat load Man. J & btuh & 98070 & 82771 \\
\hline cool load Man. J & btuh & 41985 & 38150 \\
\hline $\begin{array}{l}\text { rated capacity of existing cooling } \\
\text { equipment }\end{array}$ & btuh & 39600 & 36000 \\
\hline system oversize ratio & & 0.94 & \\
\hline envelope leakage & in & 278 & 0.94 \\
\hline ceiling insulation & R & 26 & 208 \\
\hline
\end{tabular}

ACCA Manual J calculations were performed on a room-by-room basis to estimate heating and cooling loads. Based on the Manual $\mathrm{J}$ calculations the airflow required by each room was determined as shown in Table 4. The existing air flow was compared to the ideal airflow calculated by Manual $\mathrm{J}$ to see if there were existing problems with the distribution throughout the house. The downstairs of the house had slightly lower airflow than required, and the upstairs had slightly higher, except for the master bedroom, where the airflow was too low. The homeowner had reported that the cooling was not adequate in the upstairs of the house, which indicates that there is a large conductive loss in the supply ducts, or that there is some other reason that the upstairs is getting too hot (for example, infiltration of hot attic air into the upper part of the house.)

${ }^{4}$ Retrofits included adding ceiling insulation and air sealing the building shell, which reduced the heating and cooling loads. 
Table 4. Measured and ACCA Manual J Calculated Register Airflow for the Test Residence in the Pre-Retrofit Condition.

\begin{tabular}{|l|c|c|}
\hline Location of register & $\begin{array}{l}\text { Measured flow } \\
\text { [cfm] }\end{array}$ & $\begin{array}{l}\text { Calculated flow } \\
\text { (using ACCA Manual J) } \\
\text { [cfm] }\end{array}$ \\
\hline $\begin{array}{l}\text { dining/living (near kitchen } \\
\text { door) }\end{array}$ & 101 & 156 \\
\hline dining/living (under piano) & 55 & 74 \\
\hline game room (bathroom) & 126 & 131 \\
\hline game room (laundry) & 140 & 131 \\
\hline bathroom & 28 & 8 \\
\hline master bedroom & 36 & 102 \\
\hline master bedroom (near closet) & 32 & 51 \\
\hline master bathroom & 28 & 15 \\
\hline bedroom (front of stairs) & 67 & 40 \\
\hline bedroom (corner) & 60 & 45 \\
\hline office & 76 & 43 \\
\hline girls bathroom & 29 & 9 \\
\hline
\end{tabular}

Manual D calculations to size the new ducts to deliver the required airflow out of the registers are shown in Table 5. The retrofit included a single speed air conditioner with a zoned duct system. In all cases except one the size was adequate for low velocity (when both upstairs and downstairs were calling for conditioning), but there were some cases where the size was too small for the high velocity case (when just one zone was calling). There were a total of 18 ducts sized, 8 were too small on high velocity and one was also too small on low velocity. Of these 8 that were too small, 5 were metal ducts retained from the original duct system. It was not possible to change these 5 metal ducts without considerable expense. Thus 3 of the ducts that the contractor installed were too small for the high velocity case. 
Table 5. ACCA Manual D Calculation of Duct Airflows for the Test Residence.

\begin{tabular}{|c|c|c|c|c|c|c|c|c|c|c|}
\hline \multirow[b]{2}{*}{ run } & \multirow[b]{2}{*}{ trunk } & \multirow[b]{2}{*}{$\begin{array}{l}\text { length } \\
(\mathrm{ft})\end{array}$} & \multicolumn{2}{|c|}{$\begin{array}{l}\text { Design flow } \\
(\mathrm{cfm})\end{array}$} & \multicolumn{2}{|c|}{$\begin{array}{l}\text { Post retrofit } \\
\text { duct }\end{array}$} & \multicolumn{2}{|c|}{$\begin{array}{l}\text { Velocity at } \\
\text { design flow } \\
(\mathrm{fpm})\end{array}$} & \multirow[b]{2}{*}{$\begin{array}{l}\text { optimum } \\
\text { size (in.) }\end{array}$} & \multirow[b]{2}{*}{ notes } \\
\hline & & & low & high & type & $\begin{array}{l}\text { size } \\
\text { (in.) }\end{array}$ & low & high & & \\
\hline 1 & ST1 & 2 & 237 & 386 & metal & 6 & 1100 & 1800 & 10 & $\mathrm{a}$ \\
\hline 2 & ST1 & 3 & 111 & 181 & metal & 6 & 550 & 900 & 8 & $\mathrm{a}$ \\
\hline 3 & ST2 & 6 & 187 & 305 & metal & 8 & 550 & 850 & 10 & $\mathrm{a}$ \\
\hline 4 & ST2 & 16 & 187 & 305 & metal & 8 & 550 & 850 & 10 & $\mathrm{a}$ \\
\hline 5 & ST2 & 1 & 14 & 23 & metal & 4 & 180 & 250 & 4 & \\
\hline 6 & ST5 & 7 & 158 & 403 & flex & 9 & 350 & 900 & 12 & $\mathrm{~b}$ \\
\hline 7 & ST5 & 13 & 79 & 202 & flex & 8 & 300 & 600 & 8 & \\
\hline 8 & ST5 & 10 & 25 & 63 & flex & 5 & 200 & 500 & 5 & \\
\hline 9 & ST4 & 3 & 59 & 150 & flex & 7 & $<200$ & 500 & 7 & \\
\hline 10 & ST4 & 12 & 69 & 175 & flex & 7 & $<200$ & 600 & 7 & \\
\hline 11 & ST3 & 4 & 66 & 167 & flex & 7 & $<200$ & 600 & 7 & \\
\hline 12 & ST3 & 4 & 16 & 40 & flex & 4 & $<200$ & 450 & 4 & \\
\hline ST1 & & 18 & 348 & 567 & $\begin{array}{l}\text { flex \& } \\
\text { metal }\end{array}$ & 14 & $<200$ & 500 & 14 & \\
\hline ST2 & & 25 & 389 & 634 & $\begin{array}{c}\text { flex \& } \\
\text { metal }\end{array}$ & 12 & 400 & 750 & 14 & $\mathrm{c}$ \\
\hline ST3 & & 5 & 82 & 207 & flex & 8 & $<200$ & 600 & 8 & \\
\hline ST4 & & 19 & 128 & 325 & flex & 8 & 400 & 900 & 12 & $\mathrm{~d}$ \\
\hline ST5 & & 14 & 104 & 265 & flex & 12 & $<200$ & 400 & 12 & \\
\hline ST6 & & 2 & 201 & 328 & metal & 8 & 400 & 900 & 12 & $\mathrm{a}$ \\
\hline
\end{tabular}

Table 5 notes:

Friction rate design value: $0.067 \mathrm{IWC} / 100 \mathrm{ft}$.

a: can't change, b: can change, but homeowner wants smaller flow, c: difficult to change d: can change

\section{Retrofit Selection}

\section{System Sizing}

A primary consideration for retrofits should be to downsize replacement systems. Sizing is a common problem, and generally systems are oversized which leads to short run times. Short runtimes are less efficient, have poor humidity control, have poor mixing throughout house (more stratification), provide less comfort, and can result in premature compressor/fan failure.

If the duct system is improved with increased insulation and reduced leakage, and/or the building load is reduced through envelope changes, then the equipment capacity can often be downsized. Additionally, most residential systems are already oversized and would benefit from correct sizing to reduce cyclic losses and improve part load humidity control. In many climates 


\section{DRAFT - DO NOT QUOTE}

requiring significant cooling sizing for cooling leads to extreme heating oversizing. This oversizing is because the air handler flow is determined for cooling operation. There is a limited range of furnace capacities associated with each air handler, and these heating capacities tend to be much higher than the usual factor of 1.7 times the heating load. If a house can be cooled with a lower capacity system, it therefore has the synergistic benefit of better matching the heating load. The major benefits of correct heating sizing are less cyclic losses (when hot ducts are left to cool at the end of the heating cycle) and less switching on and off that can irritate occupants. The house air will also be better mixed because a smaller system will have longer run times.

The extra cost of non-HVAC equipment related retrofits can often be compensated for by the reduced cost of a lower capacity heating and cooling system. This strategy is being used successfully in new construction (for example by various Building America Programs http://www.eere.energy.gov/buildings/building america/system.shtml). Downsizing should also include the reduction of duct diameter and register replacement in order maintain throw from registers for good room mixing. Successful examples of these tradeoffs for new construction are illustrated in Building Science case studies: http://www.buildingscience.com/buildingamerica/casestudies/default.htm

In mixed-dry, hot-dry climates where air moisture is low as in California, the evaporator cooling coil can be over-sized to increase the sensible heating ratio. The contractor in this case study matched a 3 ton outdoor coil with a 4 ton indoor coil. The airflow over the indoor coil is set based on the capacity of the outdoor coil. We were able to downsize the cooling system by $14 \%$ (0.5 tons) by reducing duct losses and improving the building envelope. The heating input capacity was also reduced from $120 \mathrm{kBtu} / \mathrm{h}(35 \mathrm{~kW})$ to $70 \mathrm{kBtu} / \mathrm{h}(20.5 \mathrm{~kW})$. Part of the reason for these reductions is the significant improvement in efficiency for the newer systems compared to the older ones.

\section{Keeping the Design Simple}

A key aspect of the keeping the design simple idea is to carefully examine the existing HVAC system to see what can be saved or salvaged for reuse. Parts of the system that are functioning well should be retained as much as possible. A good example is sheet metal ducts that are normally replaced with new flexible duct by contractors. The sheet metal ducts have much less flow resistance (and therefore less noise) and superior durability. If they can be sealed (if leaky) and insulated (if un-insulated), they should be retained if possible. In this case study we had planned to retain the sheet metal ducts in the attic and we had extensive discussions with the contractor about this issue. Unfortunately, the ducts were replaced on a day when we were not present at the job-site and the contractor removed the sheet metal ducts and replaced them with new flexible duct. The reason given by the contactor was that they were concerned that the existing ducts were undersized. This is an important misconception because flex ducts have very high flow resistance and restrict the flow more than equivalent sheet metal duct (Abushakra et al. 2002.) The contractor in this case did increase the size of the ducts when he replaced the metal duct with flex duct. 


\section{Durability}

Retrofits need to be durable so that the benefits will still be in place 25 to 50 years from now. Examples of durability concerns include not using cloth duct tape (due to thermal degradation, see Walker and Sherman 2003), and avoiding moisture problems. This retrofit case study addressed the durability issue by having better equipment sizing for better humidity control, more ventilation (by adding an economizer) for better indoor IAQ and humidity control, and use of good duct sealants to prevent entry of humid outdoor air.

\section{Retrofit Package}

Based on the results of the screening, we chose a retrofit package centered on four areas of the building system for a mixed-dry, hot-dry climate: [1] Building Envelope - tightened [2] Attic Floor Insulation -additional blown-in fiberglass [3] HVAC Equipment - new high efficiency downsized system with an economizer and zone control [4] Ducts - sealed and covered with additional insulation. The following 15 retrofit actions have been selected because they are all off the shelf existing technologies, and cover a range of energy, comfort and durability issues.

\section{Building Envelope Retrofit}

1. The sealing of the envelope was very successful - mostly because this particular house had significant large leaks that we were able to access. We sealed over $1200 \mathrm{cfm}$ of leakage at $50 \mathrm{~Pa}$ (about one-quarter of the total leakage). The sealing included: air-sealing of the attic floor plane (2 large chases) as shown in Figure 6, the installed Therma-Dome (attic pull-down staircover), leaks between the old return (which communicated with the garage) and the conditioned space, and plumbing penetrations in the conditioned space.
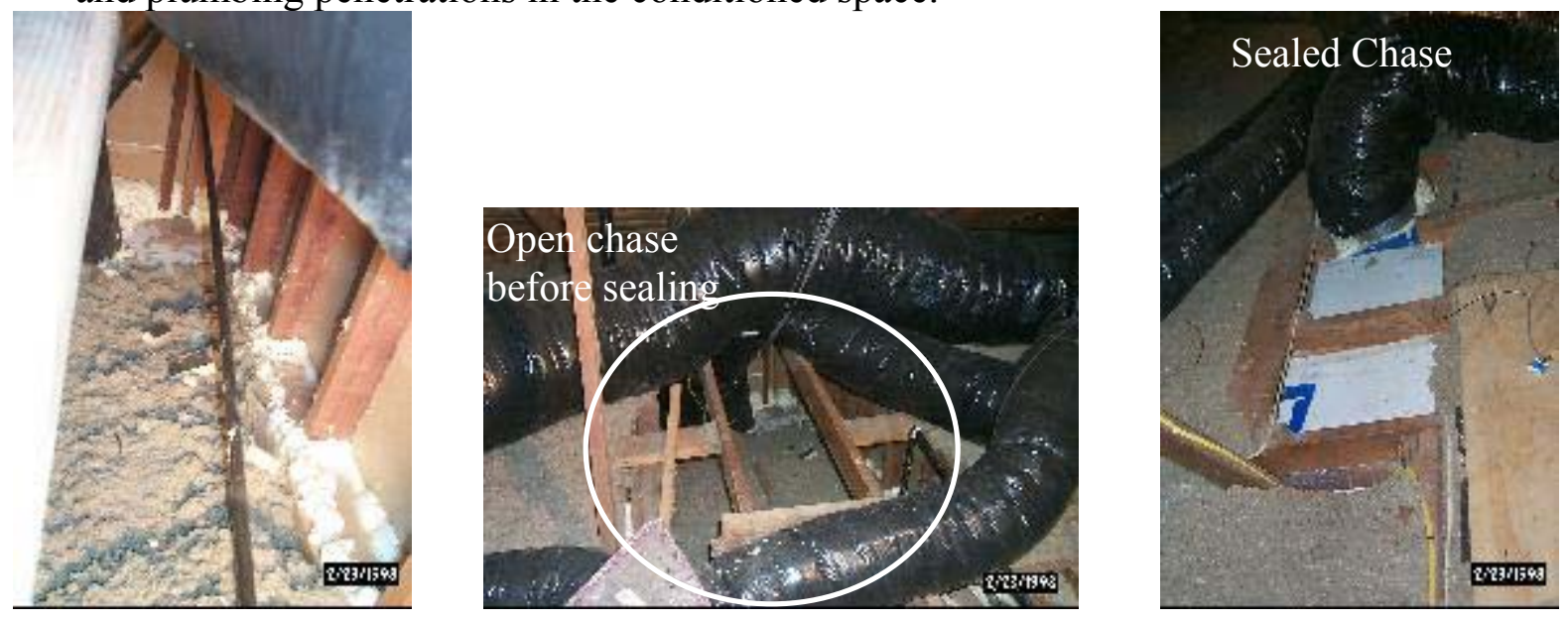

Figure 6. Sealing cavities connecting the house to the attic. Foam is a useful sealing tool for small holes and cracks at building component intersections (left). Duct board insulation can be used to block off large open areas (center and right) 
2. Unused cavity returns were sealed (after HVAC installation).

\section{HVAC Equipment Retrofit}

The selection of which equipment to use was fairly straightforward because the contractor already installs high-efficiency systems with economizers in new construction. Therefore the contractor was able to give us several options from different manufacturers that used condensing furnaces (95\% AFUE), high-efficiency air conditioners (SEER 14) and featured air handlers that remain efficient at lower speeds.

The existing low-efficiency standard central forced-air air-conditioner and furnace components were replaced with a high-efficiency system by a local contractor who was willing to collaborate with us by installing a "non-standard" system. The contractor also installed a programmable temperature-controlled economizer and a two-zone thermostat controller. The furnace, airhandler, cooling coil and plenums were relocated from the garage to the attic as shown in Figure 7. A pull-down staircase was added for better attic maintenance access (this access is important for filter changes. In particular, this household had occupants who were sensitive to IEQ issues and needed good air filtration). We would have preferred not to use the attic, because its temperature extremes lead to poor duct and equipment efficiency. In this case, there was insufficient room in the garage for the economizer ducting and the attic was the only place to put the air handler if we wanted an economizer.

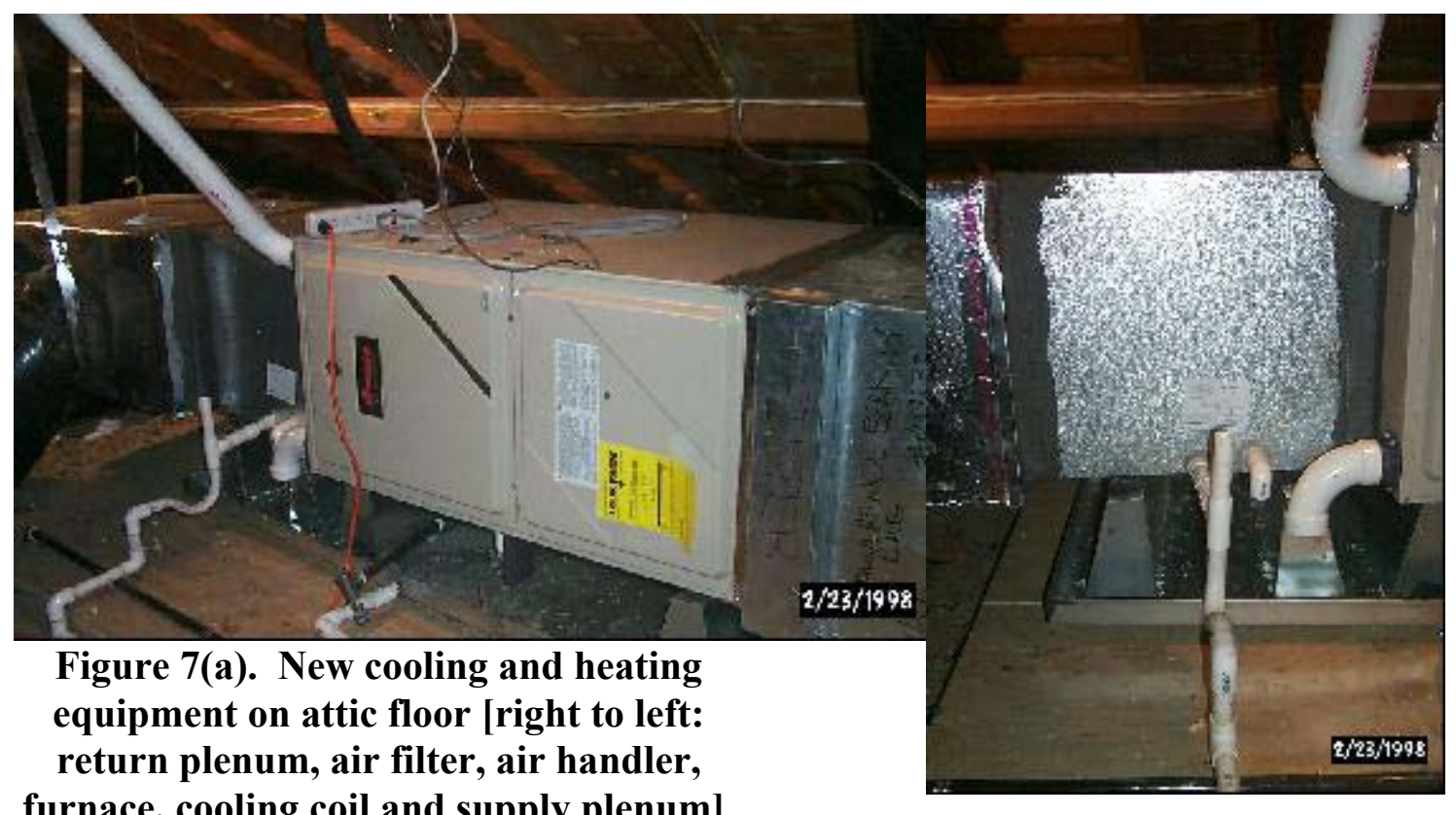

furnace, cooling coil and supply plenum].

Figure 7(b). New cooling coil with

condensate drains and top of furnace with combustion air intake and exhaust. 
The heating and cooling equipment capacity were sized using the ACCA Manual J calculation and engineering considerations derived from the monitored data. The selected heating capacity of the two-stage furnace was $66.9 \mathrm{kBtu} / \mathrm{h}(19.6 \mathrm{~kW})$ and 46.4 $\mathrm{kBtu} / \mathrm{h}(13.6 \mathrm{~kW})$ and the cooling capacity of the AC was 3 tons $(36 \mathrm{kBtu} / \mathrm{h}(10.5 \mathrm{~kW}))$. As shown in Table 3, the post-retrofit Manual $\mathrm{J}$ calculation of the heating load was 82.8 $\mathrm{kBtu} / \mathrm{h}(24.3 \mathrm{~kW})$ and the cooling load was $38.2 \mathrm{kBtu} / \mathrm{h}$ (3.2 tons) $(11.3 \mathrm{~kW})$, a reduction of $15.3 \mathrm{kBtu} / \mathrm{h}(4.5 \mathrm{~kW})$ in heating load and $3.8 \mathrm{kBtu} / \mathrm{h}(0.3$ tons $)(1.1 \mathrm{~kW})$ in cooling load. The system is slightly undersized according to ACCA Manual J, however, we know that the ACCA calculations lead to slightly oversized systems. It is interesting that the contractor recommended a system in this case that is undersized rather than oversized since we generally think that contractors oversize systems in order to reduce their callbacks. As shown in Appendix $C$, the pre-retrofit operating cooling capacity was 30.6 $\mathrm{kBtu} / \mathrm{h}$ and the sensible portion was $21.6 \mathrm{kBtu} / \mathrm{h}(6.5 \mathrm{~kW})$, which results in a sensible heating ratio of 0.71 .

3. A downsized Amana Prestige Ultra RCE high efficiency split system air-conditioning package consisting of a remote condensing unit (RCE36A2D) and an over-sized cooling coil (Aspen BBL48+X2: $48 \mathrm{kBtu} / \mathrm{h}(14 \mathrm{~kW}))$ was selected with the following specifications: $36,000 \mathrm{Btu} / \mathrm{h}(10.5 \mathrm{~kW})$ nominal capacity, 0.73 SHR and 14 EER at standard conditions and $1200 \mathrm{cfm}$. A Seasonal Energy Efficiency Ratio (SEER) of 12 or greater is the standard for an Energy Star ${ }^{\circledR}$ qualifying central air conditioner. The cooling coil was relocated from the garage to the attic. The condensing unit was relocated from a sun-exposed area behind the garage with unstable soil to a shaded area on the opposite end (north) of the house with a new slab on stable soil as shown in Figure 8. The old unit was placed on a very poor slab that has tilted considerably.
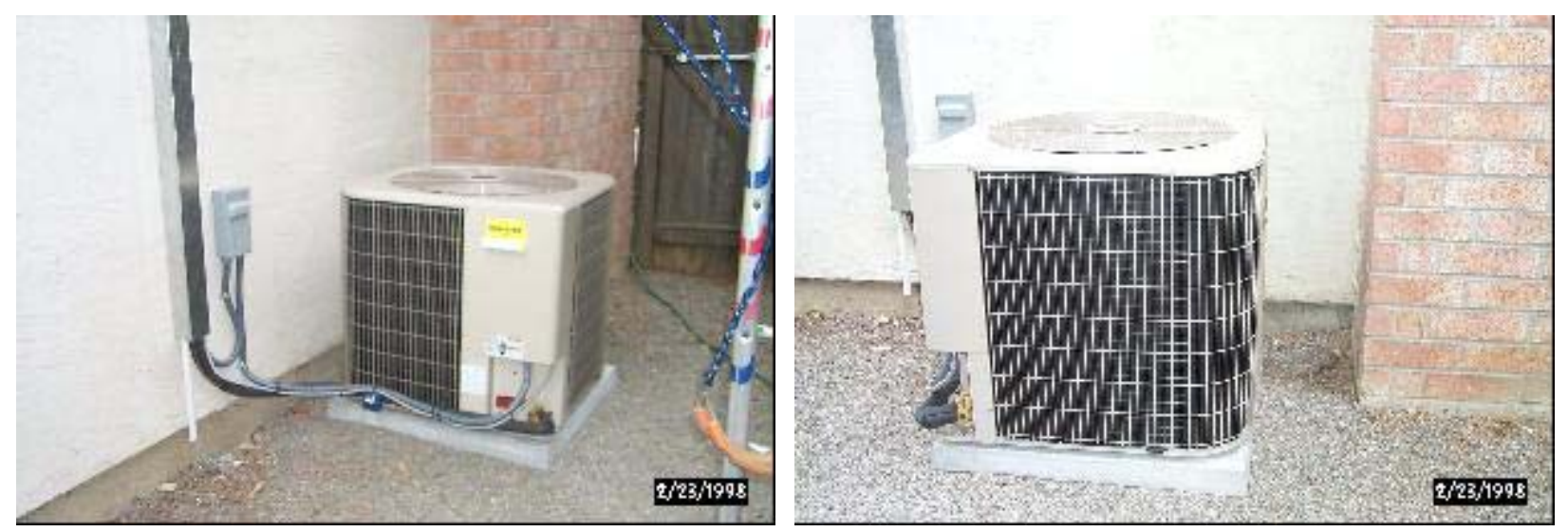

Figure 8. New AC condensing unit on shaded side of house.

4. The existing gas furnace and air-handler were removed from the garage and replaced with a downsized high-efficiency unit in the attic to allow for the use of an economizer. An Amana Air Command 95IIQ GUVA horizontal flow variable speed two-stage gas furnace (GUVA070BX40) with a $3 / 4 \mathrm{hp}$ blower motor was selected with the following specifications: $66,900 \mathrm{Btu} / \mathrm{h}(20 \mathrm{~kW})$ high-fire rate output, 46,400 $(13.5 \mathrm{~kW}) \mathrm{Btu} / \mathrm{h}$ lowfire rate output and 95.5 AFUE at standard conditions. In direct vent mode, this furnace 
is designed to draw combustion air from the outside; however it was installed to draw combustion air from the attic. The furnace flue pipe was installed through the roof as shown in Figure 9. The air handler is equipped with a General Electric ECM (Electronically Commutated Motor) (2.3 Series). These motors are advertised to be $20 \%$ more efficient than a standard motor at full load and 30\% more efficient at low speed. The DC design allows the fan speed to be easily adjusted over a large continuous range of speeds. The new system used a control strategy that slowly increased the air handler speed at the beginning of each cycle. Another advantage of these motors is that the torque does not change much with an increase in load so the fan is able to overcome ductwork resistance, and deliver a given airflow regardless of duct restriction.

5. Installed improved air filtration with a 4" $(100 \mathrm{~mm})$ pleated MERV-11 air-filter at airhandler inlet. An AirGuard PowerGuard pleated panel filter was selected and installed (20x25x4 nominal size and $23.5 \mathrm{ft}^{2}\left(150 \mathrm{~cm}^{2}\right)$ of gross media area). The filter qualifies for MERV-11 Value per ASHRAE Standard 52.2. Inspection by LBNL of the filter installation revealed a 1 " $(25 \mathrm{~mm})$ air gap at the top between the filter and slot, which allowed air to bypass the filter. The contractor was contacted to install the filter properly and eliminate the space to force all the air through the filter.

6. Installed "Smart Vent" (fresh air ventilation controller model SV10) temperaturecontrolled economizer in attic (through the roof - the economizer roof-vent is shown in Figure 10). The economizer monitors indoor and outdoor temperatures. When the set temperature difference is met the fan is turned on and a vent damper is activated allowing filtered outside air to cool the house. The damper for the fresh air inlet was located in the upper hallway return. The damper was designed so that when it opens the outdoor air inlet, it automatically closes the return air pathway through the upper hallway return grille. Another damper was installed in the return duct from the downstairs part of the house to close off this return air pathway when the fresh air inlet opens. A pressure relief damper also opens (to the attic) during economizer operation to prevent pressurization of the house. The economizer has 3 settings: On, Off, and Auto. On means the outside vent opens and the air handler fan turns on (in "fan on" mode), independent of what the inside and outside conditions are. Off means the vent closes and the air-handler fan is controlled by the zone thermostats. Auto means that the vent will open if the outdoor temp is $4^{\circ} \mathrm{C}\left(8^{\circ} \mathrm{F}\right)$ lower than indoor temperature, and if the smart vent thermostat setpoint is at least $0.5^{\circ} \mathrm{C}\left(1^{\circ} \mathrm{F}\right)$ lower than the indoor temperature (measured at the return). To adjust the indoor/outdoor differential condition (factory set at $4^{\circ} \mathrm{C}\left(8^{\circ} \mathrm{F}\right)$ ) the rheostats in the control box in the attic can be adjusted. When the outside air is cooler than the indoor air (usually at night or in shoulder season), the economizer will use the air outside to cool the house. The conditions for the economizer to operate are that the house temperature has to be $2^{\circ} \mathrm{C}\left(4^{\circ} \mathrm{F}\right)$ greater than the outside temperature and that the economizer must turn off if the indoor temperature drops to $17^{\circ} \mathrm{C}\left(62.6^{\circ} \mathrm{F}\right)$. 


\section{DRAFT - DO NOT QUOTE}

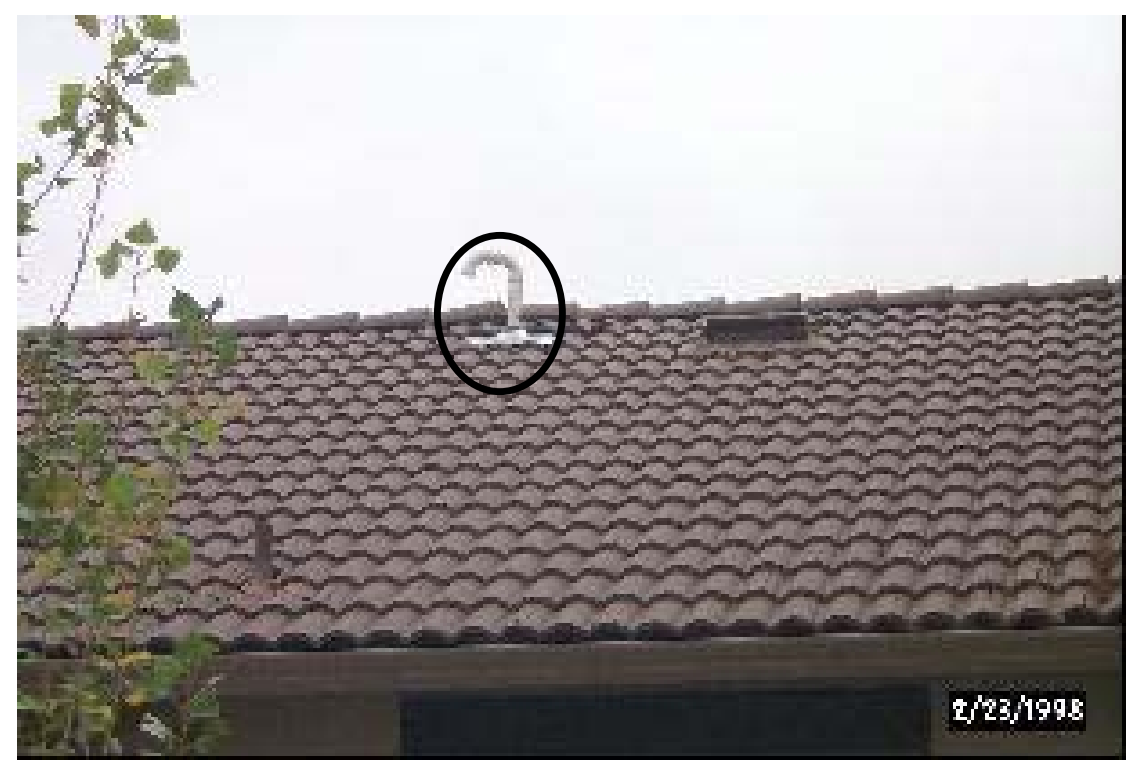

Figure 9. Installed roof mounted furnace flue pipe.

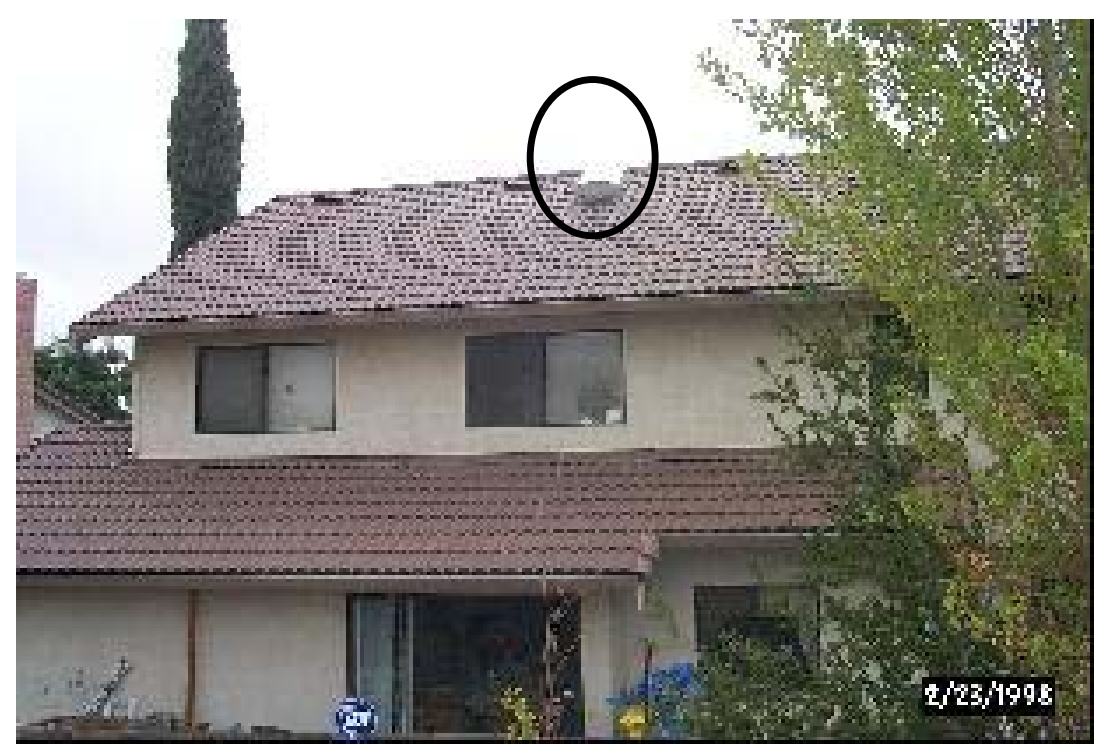

Figure 10. Installed roof mounted economizer vent. 


\section{DRAFT - DO NOT QUOTE}

7. Installed ZTE two-zone control system for separate upstairs and downstairs control and improved occupant comfort.

\section{Duct Retrofit}

The retrofit duct schematic for the supply side of the systems is shown in Figure 11.

8. Closed existing return because it was leaky and no possible way to seal it. Installed a larger upstairs return in new location (upstairs hallway ceiling) to assist in reducing temperature stratification. Installed a smaller downstairs return in new location (in the wall at the bottom of the stairway).

9. Replaced metal ducts in the attic with new R-4 flexible ducts because the contractor thought they were undersized. Initially the contractor hung the flex-ducts from the attic ceiling with smooth bends as shown in Figure 12. However, we planned to add insulation over the ducts and wanted them installed directly on the attic floor plane. The contractor then placed the new ducts on the floor per our request in Figure 13, but unfortunately did not take the time to lay the ducts with smooth bends as shown in Figure 14.

10. Added R-8 fiberglass wrap to R-4 insulated attic flex ducts for a total insulating value of about R-12 as shown in the right hand photo in Figure 15.

11. Added at least 4" (R-12) of blown-in fiberglass insulation to R-4 attic flex ducts for a total insulating value of R-16 as in Figure 15.

12. Added 4" of fiberglass wrap to R-4 insulated garage ducts for a total insulating value of about R-16.

13. New plenums were interior insulated with $1 "(\mathrm{R}-4)$ of fiberglass ductboard.

14. Our goal was to seal supply and return ducts to less than $10 \%$ of air handler flow, which is the standard for best practices (e.g. Energy Star Ducts). The ducts were sealed using manual methods and with the aerosol method developed by LBNL. But we did not meet this specification (14\% return leakage, $9 \%$ supply leakage) due to excessive leakage at the economizer outdoor air damper. Figure 16 shows the duct sealing using foam of the downstairs return. The aerosol method internally seals leaky ducts by injecting an aerosol sealant into the duct system as shown in Figure 17. 
DRAFT - DO NOT QUOTE

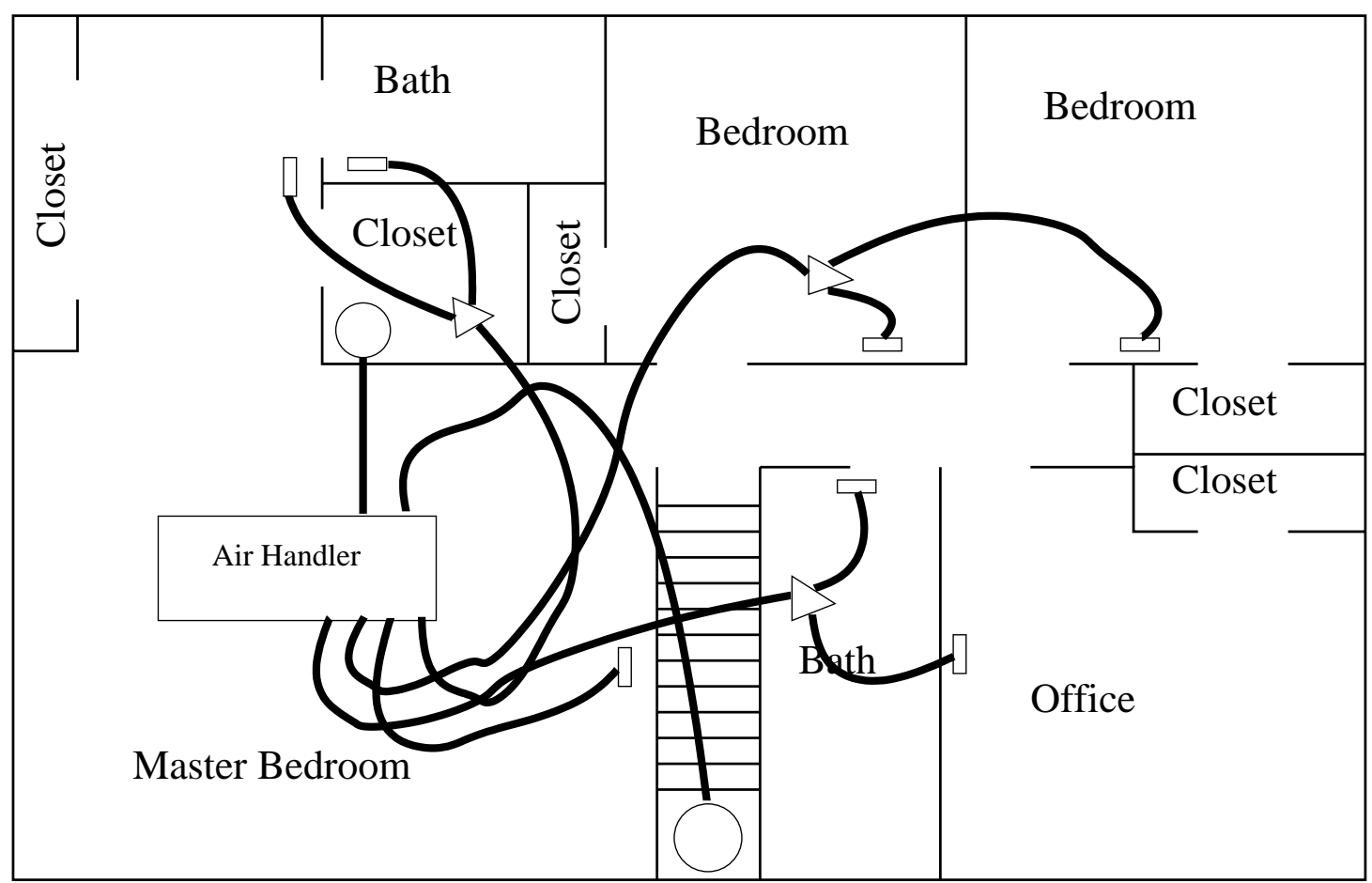

Figure 11. Retrofit duct schematic of case study residence. Changes were only made to the upper level ducts. The return was modified as well, and is not shown. 

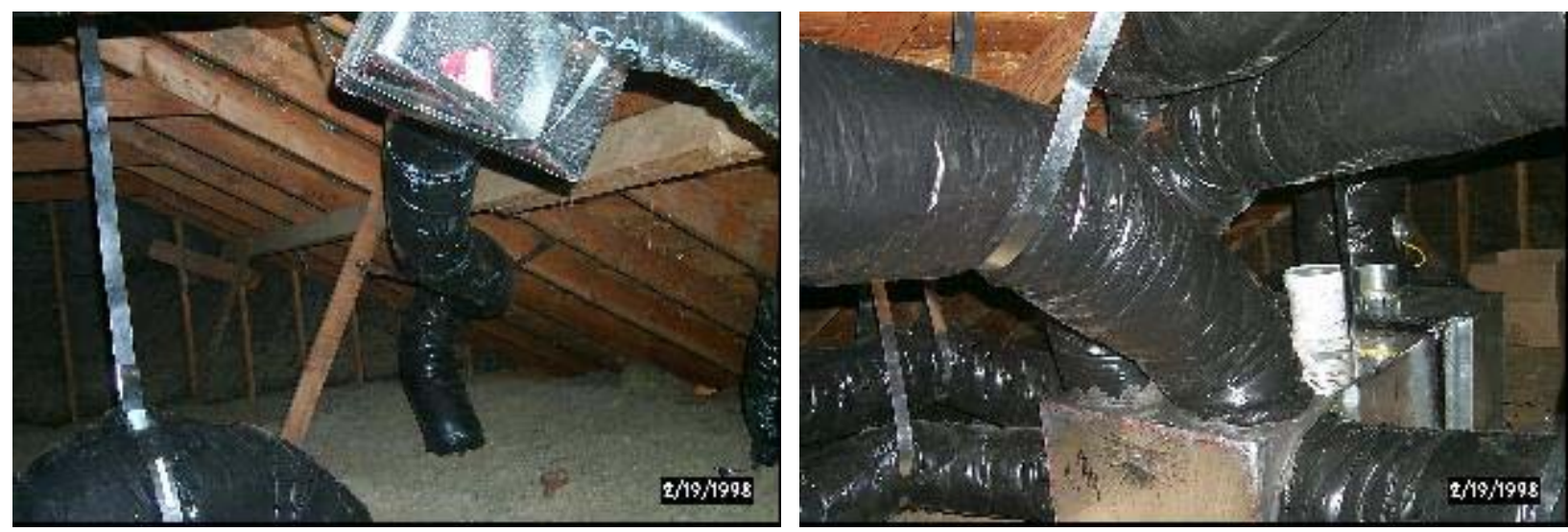

Figure 12. Initial installation of ductwork hanging from ceiling of attic [right shows smooth bend out of plenum].
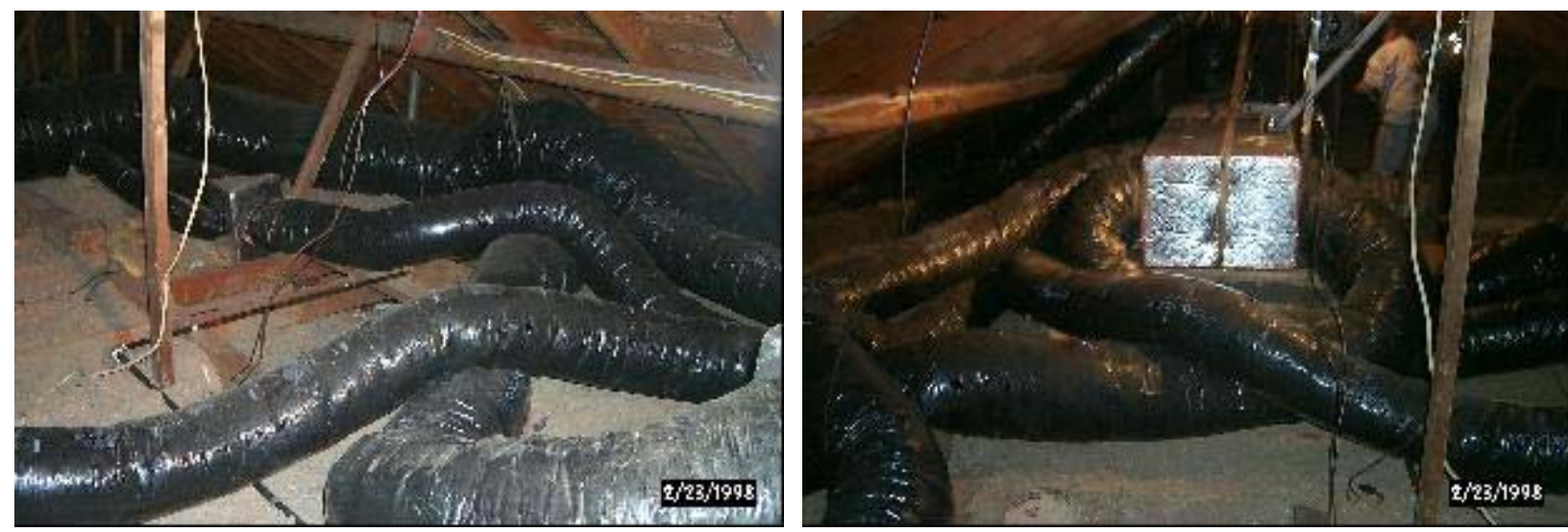

Figure 13. Second and final installed retrofit of ductwork after being moved to attic floor and before adding insulation.
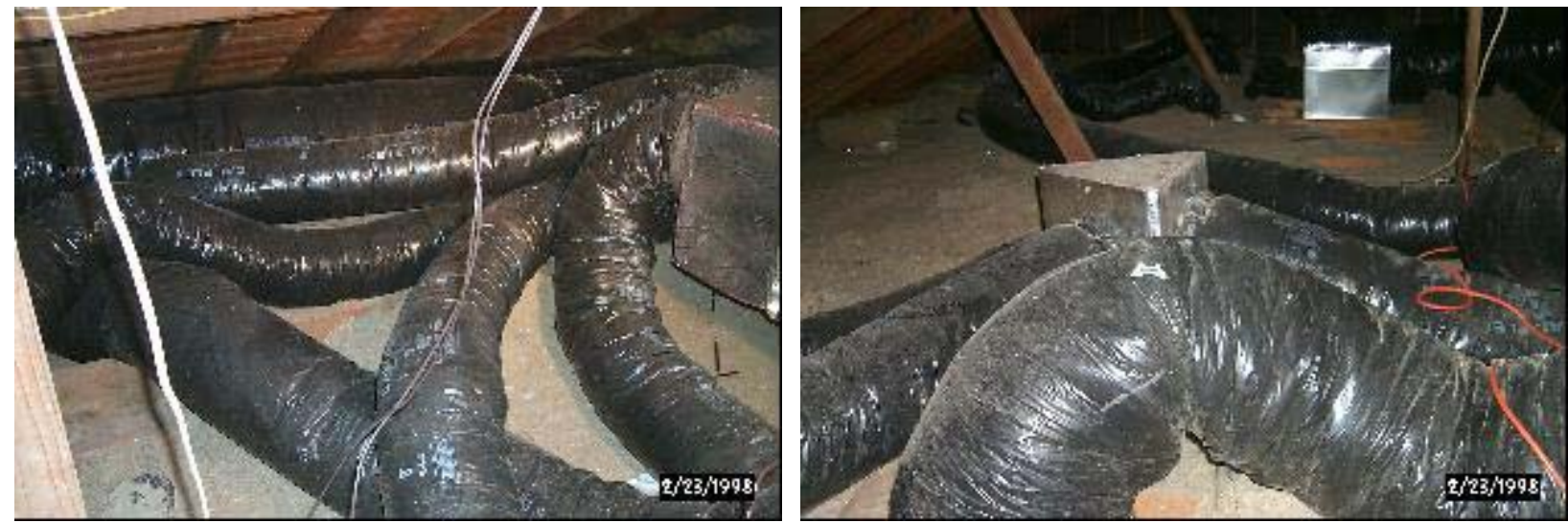

Figure 14. Second and final installed retrofit of ductwork after being moved to attic floor and before adding insulation showing tight bends. 

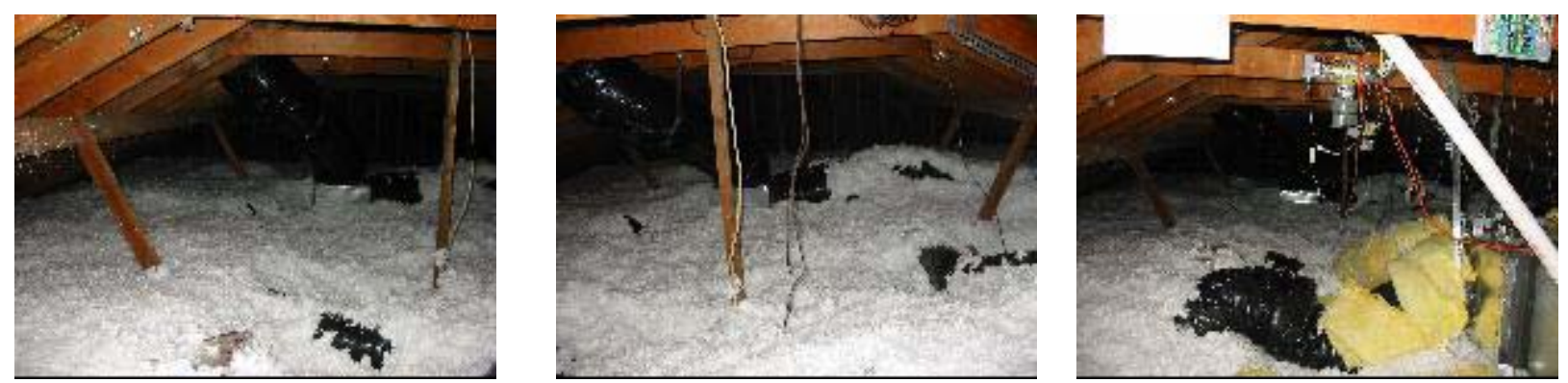

Figure 15. Attic floor with flexible ducts and additional blown-in insulation over ducts. The yellow material is fiberglass wrap insulation.

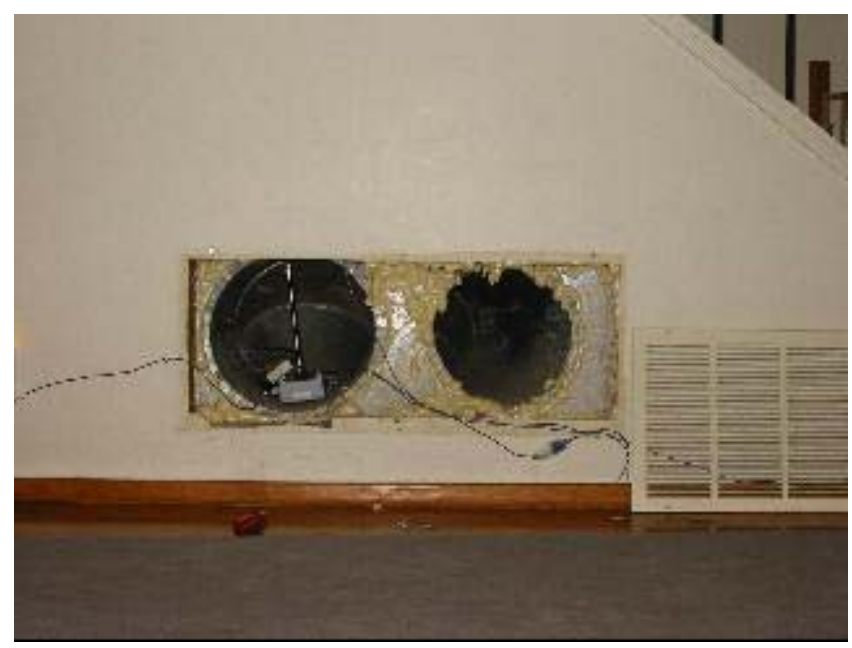

Figure 16. Duct sealing of downstairs return using foam. [the sensor that is visible is a relative humidity sensor, there is also a temperature sensor in the duct].
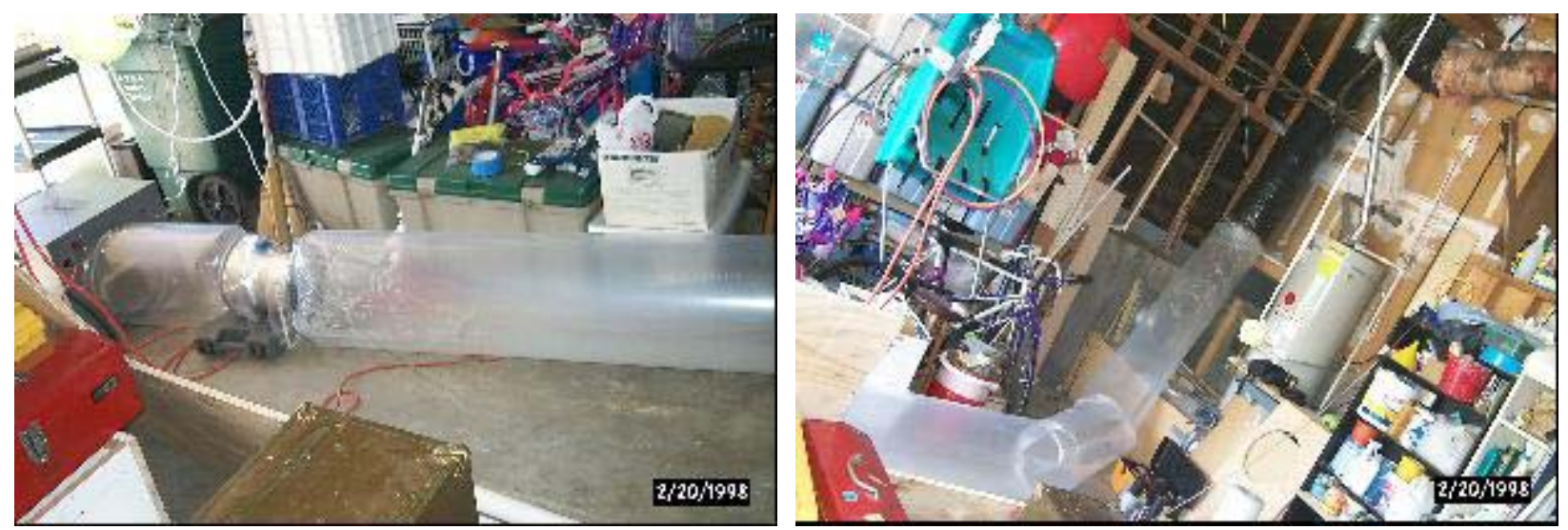

Figure 17. Aerosol apparatus for duct sealing in garage. 


\section{DRAFT - DO NOT QUOTE}

\section{Attic Retrofit}

15. Added 5" (R-17 R3.4/inch) of blown-in fiberglass insulation to R-37 attic floor plane for a total insulating value of R-54 as shown in Figure 15.

\section{Issues with Zone Control}

A 2-zone HVAC control system with independently controlled motorized dampers was installed. Each zone (second and first floors) has a thermostat with independent cooling and heating control. The control unit also has an automatic re-circulating fan cycle that can be activated to alternate between heating and equalizing cycles. Simplified and detailed wiring diagrams for the HVAC system are displayed in Appendix E

The two thermostats have On, Off, and Auto modes. There is also the thermal equalizer mode which triggers only when the upstairs is hotter than the downstairs - the upstairs supply damper closes and the fan turns on to circulate the hot upstairs air to the downstairs when the downstairs is calling for heat. With this system a heating call takes precedence over a cooling call, and the control will satisfy the heating demand first before cooling. The zone control does not control the fan speed. This is a problem since the fan is set to provide proper airflow when all of the registers are receiving air. When the zone control activates only one zone then the full volume of air is forced through approximately half the number of registers. This causes uncomfortable airflow from the registers and excessive noise. We talked to the control manufacturer to see if they were addressing this issue, and they told us that their next model of zone control would integrate the zone control and the economizer, and would be able to modulate the fan speed when used in conjunction with an ECM fan. They are currently working with one of the large air handler manufacturers to work out how the controller would integrate with the air handler.

The equalizer function works off a timing sequence for furnace run time and equalizer run time. The control can be set to run the furnace for $8,12,16$, or 20 minutes and the equalizer to be "off" or run for 6,8 , or 10 minutes. One note on the equalizer timing is that some furnaces will go through a "cool down" during equalizer run time that will extend the above times by the furnace "cool down" time. The control will not engage the equalizer function unless the furnace run time is greater than 5 minutes.

Here is an example zone control sequence: Both thermostats call for heat. Both dampers open and heat is given to both zones. If one thermostat indicates that its zone is warm enough that zone damper will close and the control will run the furnace until either the other zone satisfies or the furnace run time expires. If the furnace run time is greater than 5 minutes and total furnace run time has exceeded the furnace run time setting of the control, the control will engage the equalizer mode. The equalizer mode disengages the heating call, shutting down the burners of the furnace, closes the upstairs damper and enables the furnace fan. Depending on furnace manufacture the fan will run in either high or medium speed. This feature doesn't operate in cooling mode.

In the case study system, there are two zones electrically controlled by dampers in the supply plenum. We thought that the fan speed would be reduced when only one zone called for cooling 


\section{DRAFT - DO NOT QUOTE}

so that the fan wouldn't be trying to force the full airflow through half of the ducts. However, in the actual installation, the fan speed was the same no matter if one or two zones were calling for heating or cooling. We found that the control system was operating as designed, and there is no provision in the control system to change the fan speed when one zone shuts down. We have consulted with the zone controls manufacturer (who is neither the contractor nor the equipment manufacturer) to see if they had plans to improve their design, and they told us that they have a new controller ready for beta testing that will digitally interface with an ECM fan motor. This interface will allow the zone controller to determine the air-handler fan speed so that the speed can be lowered when just one zone is calling for heating or cooling.

In doing this modification to the zone controller there is the potential to cause problems in either heating or cooling mode. In heating mode, as airflow is reduced the temperature rise across the heat exchanger increases. If the temperature rise is too high then the heat exchanger will cycle on the high limit switch, if it is too low then condensation can form inside the heat exchanger. Both of these results can cause damage to the heat exchanger. The range of temperature rise for our installed unit is $30-60^{\circ} \mathrm{F}\left(15\right.$ to $\left.30^{\circ} \mathrm{C}\right)$. In cooling mode, if there is too little airflow across the evaporator coil, the moisture that condenses on the coil may freeze, causing an insulating layer between the coil and the air stream, or in a severe case, liquid refrigerant may make it's way back to the compressor, causing damage to the compressor. The problem of too much airflow in cooling mode will not damage the equipment, but can cause excessive noise, which is bothersome to the occupants (which is how the unit currently operates).

A potential solution is to put a temperature sensor in the supply plenum, and one inside the return grille to measure the temperature rise in heating mode, and the supply air-stream temperature in cooling mode. If these temperatures fall outside of a given range, then the controller will adjust the airflow to compensate. This control system will probably work better with multi-stage equipment than it will with single stage because the capacity of the equipment will be able to be adjusted to match either a small load (a single zone calling for conditioning) or a large load (all the zones calling for conditioning.) So in our test house, this lowering of airflow is probably easier to do in heating mode, due to the heating staging available with the new furnace.

At the house in this study, the cooling speed tap is set on "C", nominally $1100 \mathrm{cfm}$, and the heating is set on tap "B", nominally $1325 \mathrm{cfm}$ in high stage and $920 \mathrm{cfm}$ in low stage $(69 \%$ of high stage heating). The flow in fan-only operation is nominally $616 \mathrm{cfm}(56 \%$ of high stage cooling). The zone controller, which takes input signals from the thermostats and sends output signals to the air handler, uses a combination of furnace run time and temperature difference at the thermostat (difference between measured temperature and setpoint temperature) to control the number of heating stages that are brought into operation. If the delta $T$ at the thermostat is $3^{\circ} \mathrm{F}$ or more, after 5 to 6 minutes of single stage operation, then the second stage of heating is called on. We are collaborating with the controls manufacturer to implement a more complicated strategy where the second stage of heating is not allowed to come on if only one zone is calling for heating. 


\section{DRAFT - DO NOT QUOTE}

\section{Retrofit Costs}

The total cost of the HVAC and building envelope retrofits were $\$ 13,675$. The cost breakdown from the HVAC contractor was $\$ 11,201$ for materials and labor as shown in Appendix $\mathbf{F}$ to upgrade the HVAC, add an economizer, add the zoned system, add a duct return from first floor and add a pull-down staircase; $\$ 600$ to aero-seal the ducts; $\$ 990$ to add R-11 fiberglass to the attic floor and insulate over ducts with fiberglass; $\$ 325$ to insulate the garage ducts; $\$ 300$ in labor and \$150 in materials to air-seal attic floor plane; \$109 for an attic stair cover.

\section{Retrofit Effectiveness}

The Concord test house was monitored during the pre-retrofit period for about eight weeks from July $12^{\text {th }}$ through September $18^{\text {th }}$ 2002. The house envelope and HVAC system were then retrofitted. Data collection then resumed on October $2^{\text {nd }}$ for the post-retrofit period. The weather at this point was too cold for the cooling system to operate, so we were unable to get post retrofit cooling system data.

The instrumentation and measurements are described in detail in Appendix B.

Examination of the 10-second data shows the total AC power increased with increasing outdoor air temperature at $69 \mathrm{~W} /{ }^{\circ} \mathrm{C}$ and likewise with compressor motor power at $70 \mathrm{~W} /{ }^{\circ} \mathrm{C}$. However, the condenser and air-handler fan power decreased with increasing outdoor air temperature at $-1.2 \&$ $-0.3 \mathrm{~W} /{ }^{\circ} \mathrm{C}$. The Energy Efficiency Ratio (EER) decreased at $-0.1 /{ }^{\circ} \mathrm{C}$ of outdoor air temperature and cooling capacity decreased at $-0.3 \mathrm{kBtu} / \mathrm{h} /{ }^{\circ} \mathrm{C}$.

Duct leakage was measured at 13\% (196 $\left.\mathrm{cfm}_{25}\right)$, where the Energy Star leakage requirement of $<10 \%\left(150 \mathrm{cfm}_{25}\right)$ total leakage is the target. The leakage breakdown is $4 \%\left(60 \mathrm{cfm}_{25}\right)$ supply - almost all in the cabinet and supply plenum and 9\% $\left(136 \mathrm{cfm}_{25}\right)$ return - almost all of which is in the economizer damper box. The economizer housing was damaged during installation, where nearly $136 \mathrm{cfm} 25$ of leakage was measured.

1. The air filter has a 1 " bypass between the top of the filter and the sheet metal housing. This problem was mentioned to the contractor, and it was fixed with a piece of sheet metal. Unfortunately, the sheet metal fix was installed on the opposite side of the filter from the sheet metal fix at the back of the filter, so the bypass still exists.

2. It seems the contractor does not weigh charge, the condensing unit comes pre-charged and no more was added. The contractor normally would check the charge with a superheat test, but the weather was not warm enough to do one in this case.

3. The tension in the springs of the zone selection dampers was not adjusted so that they open all the way against pressure. 


\section{DRAFT - DO NOT QUOTE}

4. The upstairs was not receiving enough heat as observed by the homeowners. The contractor installed two sheet metal scoops to affect airflow and heating.

\section{Commissioning}

Commissioning has its roots in the shipbuilding industry, and has made its way to the industrial sector, but is not common practice for residences. Our experience with construction practices in residences leads us to think that commissioning is a good idea when a house is newly constructed, before or after a major remodel, or when ownership changes hands. We also found that an important part of the commissioning process is to have detailed oversight of contractor activities. Houses need maintenance, and problems can arise, unknown to the homeowner. Wray et al. (2003) have developed a recommended commissioning procedure for residences, which is similar to the diagnostics we have outlined in this paper. A flow chart of the recommended commissioning procedure, along with references to protocols for each of the testing procedures, can be found in Appendix D. A sample commissioning report can also be found for this house in the pre-retrofit condition.

\section{Diagnostics and Screening in Four Cold Climate Houses}

A survey of four houses with basements were included in this study in order to see if the checklist would apply differently to these houses where HVAC systems are often located in these semi-conditioned basement spaces. These houses were in two cold climates: Minnesota and Massachusetts, where basement construction is common. These houses were diagnosed, and recommendations were made, but they were not retrofitted as part of the study. The summary of diagnostic results, and recommendations for these houses can be found in Appendix G. All four of the cold climate houses had full basements. We pressurized the houses with the basement door closed and then measured the pressure difference between the basement and the house. Three of the basements that we tested were essentially inside the air boundary of the house. The other basement was about half inside and half outside. All the houses had at least one supply register in the basement. One of the basements was insulated on the interior of the foundation walls, one house had insulation on half of the basement ceiling and the band joist, but no insulation on the foundation walls, an the other two houses had insulation on some of the foundation walls, and some of the basement ceiling, but not in a consistent manner. Our recommendation in all of these cases was to bring the basement inside the pressure boundary by airsealing the rim joist and any penetrations between the basement and outside. We also recommended to insulate the basement walls wherever they were not insulated. This brings the basement ducts inside the envelope so there are no losses to outside. The basement ducts would only need to be sealed if they are so significant that they are causing distribution problems. If the basement cannot be brought inside the pressure boundary of the house (because the leaks cannot be found and sealed) then the evaluation of whether to seal the ducts can be made using the duct pressurization test or the delta q test, which both give an estimation of duct leakage to outside.

One issue that needs to be addressed if the basement is brought into conditioned space is that the combustion appliances are generally located in this space, and some provisions need to be made 


\section{DRAFT - DO NOT QUOTE}

for makeup combustion air. The best option is to install sealed combustion appliances, which take combustion air directly from outside. The appliances also have powered exhaust vents so the danger of back drafting is eliminated. One of the houses that we surveyed had a sealed combustion furnace and water heater. One of the houses had an outdoor air inlet into the return duct, and a supply register (but no return) in the room where the furnace was located. Thus, the furnace room is pressurized to avoid back drafting of the furnace and water heater. This practice complies with Minnesota Building Code, but we don't recommend it because of the additional heat load on the house due to the outdoor air inlet into the return.

\section{Lessons Learned for Best Practices Guidelines}

Our experience from the field pilot study has given us some insights for the best practices guidelines (Walker 2003). For example, we had planned to retrofit the attic to be an insulated unvented space, however the building code officials were not happy with this. Various options were discussed - including creating a vented space behind a radiant barrier, adding windows to make it "living space", and the need to put drywall over the roof deck insulation because of the fire hazard associated with having the furnace in the attic. With sufficient time and resources we probably could have persuaded the code authorities to allow a sealed attic, however, because we needed to complete the retrofits as soon a possible, we retained the vented attic and buried the ducts in additional ceiling insulation. This method of burying the ducts also eliminates radiant exchange between duct surfaces and hot undersides of the pitched roof surfaces during air conditioning operation. The caveat is that burying ducts in insulation may not be suitable in more humid climates where there is the potential of condensation on the outside of the ducts.

Like most people considering renovations, we had limits of time and budget, that meant that we had to provide less innovative solutions. In other new construction projects we have worked on we have faced the same issues - innovations in construction practice are strongly resisted by building code officials. This resistance severely limits the range of renovations that can be easily carried out. Given the strict conservatism of code officials, it is unlikely that these issues can be dealt with on an individual project basis without extensive advance planning. Rather, we need to be able to show specific examples of retrofits that are proposed. We hope that with research projects like the current study, and the continuing efforts of other building scientists that sufficient evidence for accepting some innovative building changes will become more widely accepted.

We spent considerable time with a contractor looking at many retrofit options for the test house. A key issue was where to locate the air handler. Including an economizer in the new system meant that the existing garage location was not useable because of the difficulty in running the large ducts associated with the economizer. The alternative was to put the air handler in the attic (this is the standard retrofit performed by the contractor) and reduce the attic temperature extremes. As discussed above - this created additional issues with code officials.

Other issues that need to be considered are the need to ensure good communication with the homeowner and be able to discuss homeowner concerns (particularly if the retrofit is innovative). It is essential to find a contractor who is willing to do something out of the ordinary and persuade them to change the equipment they use and work crew practices. Ensuring that the 


\section{DRAFT - DO NOT QUOTE}

work is a collaborative effort has benefits because contractors may have good ideas they want to try out or, knowledge of alternative equipment. When having a contractor do something new or unusual they need constant supervision to ensure that you get what you want (For example., we had wanted to reuse the non-leaky low flow resistance sheet metal duct already installed in our test house, but the installers removed it all and replaced it with flexible duct, which is what they normally do in a retrofit situation).

\section{Lessons Learned}

1. Code officials are a significant barrier to the adoption of innovative retrofits.

2. Contractors, like code officials, are unfamiliar with innovative retrofits and need to be willing to learn on the job. Innovative retrofits have higher labor costs (and possibly material as well) until the contractor has gained enough experience to adequately finish a job with fewer hours.

3. Ensure that the work is a collaborative effort - contractors may have good ideas they want to experiment with or knowledge of alternative equipment that can be valuable.

4. Constant communication and supervision is required to ensure extraordinary retrofits are carried out as desired. A pre-agreed upon workplan between the contractor and client would aid in the communication process.

5. Develop a manual and checklist to help installers.

6. Keep thorough notes and communicate this information with installers.

7. Installers need training on new equipment/techniques.

8. Commissioning of retrofitted systems is required, and more complex systems like zoning dampers and variable speed systems need to be thoroughly checked for proper design operation. 


\section{DRAFT - DO NOT QUOTE}

\section{Acknowledgements}

This work was supported by and the Assistant Secretary for Energy Efficiency and Renewable Energy, Building Technologies, of the US Department of Energy (DOE) under contract No. DEAC03-76SF00098. The authors would like to thank Darryl Dickerhoff, Duo Wang, Douglas Brenner, Brian Smith and Nance Matson of LBNL, Ananda Harzell (CSG), Rick Wylie (Beutler Heating and Air Conditioning), and Stacy Hunt (IBACOS). 


\section{DRAFT - DO NOT QUOTE}

\section{References}

Abushakra, B., I. Walker and M. Sherman. 2002. "A Study of Pressure Losses in Residential Air Distribution Systems". Proceedings of ACEEE Summer Study 2002, American Council for an Energy Efficient Economy. Washington, D.C. Lawrence Berkeley National Laboratory Report LBNL 49700. Berkeley, CA.

ASTM E779-99. 1999. "Standard Test Method for Determining Air Leakage Rate by Fan Pressurization" Annual Book of ASTM Standards Vol. 04.11. American Society for Testing and Materials.

ASTM E1554-94. 1994. "Standard Test Methods for Determining External Air Leakage of Air Distribution Systems by Fan Pressurization". Annual Book of ASTM Standards Vol. 04.11. American Society for Testing and Materials.

ASTM E1186-03. 2003. "Standard Practices for Air Leakage Site Detection in Building Envelopes and Air Retarder Systems". Annual Book of ASTM Standards Vol. 04.11. American Society for Testing and Materials.

ASTM E1827-96. 2002. "Standard Test Methods for Determining Airtightness of Buildings Using an Orifice Blower Door". Annual Book of ASTM Standards Vol. 04.12. American Society for Testing and Materials.

Cool Roofing Materials Database (CRMD). 2001. http://eetd.lbl.gov/coolroof. Lawrence Berkeley National Laboratory. Berkeley, CA.

Consortium for Energy Efficiency (CEE). 2000. "Specification of Energy-Efficient Installation and Maintenance Practices for Residential HVAC Systems”. Boston, MA.

Jump, D. and M. Modera. 1994. "Energy Impacts of Attic Duct Retrofits in Sacramento Houses”. Lawrence Berkeley National Laboratory Report LBNL-35375. Berkeley, CA.

Jump, D., I. Walker and M. Modera. 1996. "Field Measurements of Efficiency and Duct Effectiveness in Residential Forced Air Distributions Systems". Lawrence Berkeley National Laboratory Report LBNL-38537. Berkeley, CA.

Sherman, M. and D. Dickerhoff. 1994. "Air-Tightness of U.S. Dwellings," In Proceedings, 15th AIVC Conference: The Role of Ventilation, Vol. 1, Coventry, Great Britain:Air Infiltration and Ventilation Centre, 1994, pp. 225-234.

Walker, I., D. Dickerhoff and M. Sherman. 2002. "The DeltaQ Method of Testing the Air Leakage of Ducts". Proceedings of ACEEE Summer Study 2002, American Council for an Energy Efficient Economy. Washington, D.C. Lawrence Berkeley National Laboratory Report LBNL 49749. Berkeley, CA. 


\section{DRAFT - DO NOT QUOTE}

Walker, I. and M. Modera. 1998. "Field Measurements of Interactions Between Furnaces and Forced Air Distributions Systems". ASHRAE Transactions Vol. 104, Pt. 1B, pp.1805-1816 ASHRAE. Atlanta, GA.

Walker, I., M. Sherman, M. Modera and J. Siegel. 1998. "Leakage Diagnostics, Sealant Longevity, Sizing and Technology Transfer in Residential Thermal Distribution Systems". Lawrence Berkeley National Laboratory Report LBNL-41118. Berkeley, CA.

Walker, I., M. Sherman, J. Siegel and M. Modera. 1999. "Effects of Duct Improvement and EnergyStar Equipment on Comfort and Energy Efficiency". Lawrence Berkeley National Laboratory Report LBNL-43723. Berkeley, CA.

Walker, I., M. Sherman, J. Wempen, D. Wang, J. McWilliams and D. Dickerhoff. 2001. "Development of a New Duct Leakage Test: DeltaQ". Lawrence Berkeley National Laboratory Report LBNL 47308. Berkeley, CA.

Walker, I., C. Wray, D. Dickerhoff and M. Sherman. 2002. "Evaluation of Flow Hood measurements for Residential Register Flows". Lawrence Berkeley National Laboratory Report LBNL 47382. Berkeley, CA.

Walker, I.S. and Wray, C.P. 2003. "Evaluation of flow capture techniques for measuring HVAC grille air flows". ASHRAE Transactions (in p ress) Lawrence Berkeley National Laboratory Report LBNL-51550. Berkeley, CA.

Walker, I.S. 2003. Best Practices Guide for Residential HVAC Retrofits. LBNL 53592.

Walker, I.S. and Sherman, M.H.. 2003. "Sealant Longevity for Residential Ducts". Durability of Building and Construction Sealants and Adhesives, ASTM STP 1453, A. Wolf Ed., American Society for Testing and Materials, West Conshohocken, Pa. (LBNL 50189).

Wray, C. and M. Sherman. 2001. "Residential Commissioning to Assess Envelope and HVAC System Performance". Lawrence Berkeley National Laboratory Report LBNL-47412. Berkeley, CA. http://epb.lbl.gov/Publications/lbnl-47412.pdf.

Wray, C., I. Walker and M. Sherman. 2002. "Accuracy of Flowhoods in Residential Applications". Proceedings of ACEEE Summer Study 2002, American Council for an Energy Efficient Economy. Washington, D.C. Lawrence Berkeley National Laboratory Report LBNL 49697. Berkeley, CA.

Wray, C., I. Walker, J. Siegel and M. Sherman. 2002. "Practical Diagnostics for Evaluating Residential Commissioning Metrics". Lawrence Berkeley National Laboratory Report LBNL45959. Berkeley, CA. http://epb.lbl.gov/Publications/lbnl-45959.pdf. 


\section{DRAFT - DO NOT QUOTE}

Wray, C., I. Walker and M. Sherman. 2003. "Instrumented Home Energy Rating and Commissioning". Lawrence Berkeley National Laboratory Report LBNL-52216. Berkeley, CA. http://epb.lbl.gov/Publications/lbnl-52216.pdf.

US Department of Energy (USDOE). 2001. "Choosing or Upgrading Your Central Air Conditioner". Office of Building Technology, State and Community Programs". http://www.eren.doe.gov/buildings/heatcool_cenair.html. 


\section{Appendix A. Field Surveys of Four Houses in California for Retrofitting} Table A.1. Diagnostic Checklist for Concord House.

\begin{tabular}{|c|c|c|c|}
\hline $\begin{array}{l}\text { Measurement/ } \\
\text { Observation }\end{array}$ & Potential Target value & Actual Value & $\begin{array}{l}\text { Potential Retrofit } \\
\text { Action }\end{array}$ \\
\hline Duct leakage & $<10 \%$ of air handler flow & S $12 \% ;$ R $33 \%$ & Seal ducts: aeroseal/tape/mastic \\
\hline Air flows at registers & Compare to ACCA manual J & $\begin{array}{l}\text { Sum of supplies and } \\
\text { returns: S } 683 ; \mathrm{R} 540 . \\
\text { Several duct runs had } \\
\text { low airflow. }\end{array}$ & $\begin{array}{l}\text { Replace registers, open/close } \\
\text { dampers. }\end{array}$ \\
\hline Air handler flow & $\begin{array}{l}\text { Cooling: } 1400 \text { based on nameplate, } 900 \text { based } \\
\text { on measured capacity. } \\
\text { Heating: } 12.5 \mathrm{cfm} / \mathrm{kBtu} / \mathrm{h}\end{array}$ & $804 \mathrm{cfm}$ & $\begin{array}{l}\text { Replace filters, fix duct restrictions, } \\
\text { change fan speed, replace fan with } \\
\text { high efficient unit, add extra returns } \\
\text { in return restricted systems }\end{array}$ \\
\hline Filter Condition & Clean and at least MERV $6^{5}$ & $\begin{array}{l}\text { Non-operational } \\
\text { electrostatic }\end{array}$ & $\begin{array}{l}\text { Replace with MERV } 6 \text { or better. Use } \\
4 \text { inch filters. }\end{array}$ \\
\hline Thermostat Setting & Heating: $68^{\circ} \mathrm{F}\left(20^{\circ} \mathrm{C}\right)$ Cooling: $78^{\circ} \mathrm{F}\left(25^{\circ} \mathrm{C}\right)$ & Programmable & None \\
\hline $\begin{array}{lr}\text { Spot Ventilation } \\
\text { power consumption }\end{array}$ & $\begin{array}{l}2.5 \mathrm{cfm} / \mathrm{W}(1.2 \mathrm{~L} / \mathrm{s} / \mathrm{W}) . \text { Look up in HVI } \\
\text { directory (www.hvi.org) }\end{array}$ & $\mathrm{N} / \mathrm{A}$ & None \\
\hline Equipment capacity & Manual S: 3.5 tons on nameplate & 2.3 tons measured & $\begin{array}{l}\text { Replace with more efficient and } \\
\text { slightly smaller unit. }\end{array}$ \\
\hline Refrigerant charge & Use superheat or subcooling tests & Leak in refrigerant line & $\begin{array}{l}\text { Fix leak and add refrigerant or } \\
\text { replace unit. }\end{array}$ \\
\hline $\begin{array}{l}\text { Age and Condition of } \\
\text { HVAC system }\end{array}$ & $\begin{array}{l}\text { Clean and undamaged. } \\
\text { Determine system age. }\end{array}$ & $\begin{array}{l}\text { Poor condition. Age } \\
\text { unknown. }\end{array}$ & Replace system. \\
\hline $\begin{array}{l}\text { Location of } \begin{array}{l}\text { HVAC } \\
\text { system equipment and } \\
\text { ducts }\end{array} \\
\end{array}$ & Inside conditioned space & Garage & $\begin{array}{l}\text { Seal and insulates duct locations to } \\
\text { make them more like conditioned } \\
\text { space, or move system location. }\end{array}$ \\
\hline Window $\mathrm{A} / \mathrm{C}$ units & EnergyStar compliant & None & None \\
\hline Envelope leakage & Normalized Leakage Area reduction of 0.35 & $\begin{array}{l}\text { ELA: } 278 \text { in } 2 ; \text { NLA } \\
0.95\end{array}$ & $\begin{array}{l}\text { Airseal plumbing penetrations, attic } \\
\text { chases, top plates, and other } \\
\text { unintentional openings. Reduce to } \\
\text { NLA } 0.6\end{array}$ \\
\hline Moisture testing & No moisture problems & None & None \\
\hline House insulation & $\begin{array}{l}\text { Ceiling: R-30 (RSI 5.3) minimum, R-49 (RSI 8.6) } \\
\text { in cold/severe cold climate. Floor over } \\
\text { crawlspace:R- } 25 \text { (RSI 4.4). Basement walls: R10 } \\
\text { (RSI 1.8), Basement Floor or slab usually } \\
\text { depends on local codes. Walls: Cavity should be } \\
\text { completely filled with insulation. }\end{array}$ & $\begin{array}{l}\text { Attic: } \quad 4-5 \quad \text { inches } \\
\text { cellulose } \quad(\sim \mathrm{R} \quad 15) \text {. } \\
\text { Walls: } \mathrm{R}-11\end{array}$ & $\begin{array}{l}\text { Add at least } 6 " \text { cellulose insulation to } \\
\text { attic. }\end{array}$ \\
\hline Windows & $\begin{array}{l}\text { Double-glazed, low-e. Shaded in cooling } \\
\text { dominant climates }\end{array}$ & Single glazed aluminum & $\begin{array}{l}\text { Replace windows. (Alarm system } \\
\text { must be replaced at same time.). }\end{array}$ \\
\hline Window shading & Located on south and/or west facing windows & None & Add shading to reduce solar loads \\
\hline Solar radiation control & $\begin{array}{l}\text { Radiant barrier in attic, low absorptivity roof } \\
\text { coatings }\end{array}$ & None & $\begin{array}{l}\text { Add reflective paint to roof and/or } \\
\text { sunshades for windows. }\end{array}$ \\
\hline $\begin{array}{l}\text { Wall, floor and ceiling } \\
\text { construction }\end{array}$ & Space for ducts/ vents/ insulation & $\begin{array}{l}\text { Attic has plenty of } \\
\text { space. }\end{array}$ & Add insulation in attic. \\
\hline $\begin{array}{l}\text { Occupant survey } \\
\text { Ask occupants to report } \\
\text { problems }\end{array}$ & No problems & $\begin{array}{l}\text { Upstairs hotter than } \\
\text { downstairs. Feels dust } \\
\text { blowing when AH is } \\
\text { on. Windows rattle. }\end{array}$ & $\begin{array}{l}\text { Add zoned system to condition first } \\
\text { and second floor independently. } \\
\text { Duct sealing for dust being drawn in } \\
\text { through return. Possibly replace } \\
\text { windows. }\end{array}$ \\
\hline
\end{tabular}

${ }^{5}$ MERV is an industry standard rating system for air filters, it stands for Minimum Efficiency Report Value determined using ASHRAE Standard 52.2 
DRAFT - DO NOT QUOTE

Table A.2. Diagnostic Checklist for Larkspur House.

\begin{tabular}{|c|c|c|c|}
\hline $\begin{array}{l}\text { Measurement/ } \\
\text { Observation }\end{array}$ & Potential Target value & Actual Value & $\begin{array}{l}\text { Potential Retrofit } \\
\text { Action }\end{array}$ \\
\hline Duct leakage & $<10 \%$ of air handler flow & S 10\%; R 17\% & Seal ducts: aeroseal/tape/mastic \\
\hline Duct insulation & $\begin{array}{l}\text { R6 (RSI 1) to R8 (RSI 1.4) for all ducts outside } \\
\text { conditioned space }\end{array}$ & $?$ & Add insulation to ducts \\
\hline Air flows at registers & Compare to ACCA manual J & $\begin{array}{l}\text { Sum of supplies and } \\
\text { returns: S 1120; R } \\
\text { N/A. }\end{array}$ & $\begin{array}{lll}\text { Replace } & \text { registers, open/close } \\
\text { dampers. } & \end{array}$ \\
\hline Air handler flow & $\begin{array}{l}\text { Cooling: } 1200 \mathrm{cfm} \text { based on nameplate } \\
\text { Heating: } 12.5 \mathrm{cfm} / \mathrm{kBtu} / \mathrm{h}\end{array}$ & $1216 \mathrm{cfm}$ & None \\
\hline Filter Condition & Clean and at least MERV $6^{6}$ & Poor fitting air filter & $\begin{array}{l}\text { Replace with new MERV } 6 \text { or } \\
\text { better. }\end{array}$ \\
\hline Thermostat Setting & Heating: $68^{\circ} \mathrm{F}\left(20^{\circ} \mathrm{C}\right)$ Cooling: $78^{\circ} \mathrm{F}\left(25^{\circ} \mathrm{C}\right)$ & Programmable & None \\
\hline Spot ventilation & $\begin{array}{l}50 \mathrm{cfm} \text { each bathroom } \\
100 \mathrm{cfm} \text { each kitchen }\end{array}$ & N/A & None \\
\hline $\begin{array}{lrr}\text { Spot } & \text { Ventilation } \\
\text { power consumption }\end{array}$ & $\begin{array}{l}2.5 \mathrm{cfm} / \mathrm{W}(1.2 \mathrm{~L} / \mathrm{s} / \mathrm{W}) . \text { Look up in HVI directory } \\
\text { (www.hvi.org) }\end{array}$ & $\mathrm{N} / \mathrm{A}$ & None \\
\hline Equipment capacity & Manual S: 3 tons on nameplate & 2.8 tons measured & None \\
\hline Refrigerant charge & Use superheat or subcooling tests & Charged in 2000 & None \\
\hline $\begin{array}{l}\text { Age and Condition of } \\
\text { HVAC system }\end{array}$ & $\begin{array}{l}\text { Clean and undamaged. } \\
\text { Determine system age. }\end{array}$ & $\begin{array}{lr}\text { Condensing } & \text { coil } \\
\text { dirty. System } & 27 \\
\text { years old. } & \end{array}$ & Clean coil or replace system. \\
\hline $\begin{array}{l}\text { Location of HVAC system } \\
\text { equipment and ducts }\end{array}$ & Inside conditioned space & Crawlspace & $\begin{array}{l}\text { Seal and insulates duct locations } \\
\text { to make them more like } \\
\text { conditioned space, or move system } \\
\text { location. }\end{array}$ \\
\hline Window $\mathrm{A} / \mathrm{C}$ units & EnergyStar compliant & None & None \\
\hline Multiple systems/zoning & $\begin{array}{l}\text { System and controls in good working order and } \\
\text { providing good comfort for occupants }\end{array}$ & None & None \\
\hline Envelope leakage & Normalized Leakage Area reduction of 0.35 & $\begin{array}{l}\text { ELA: } 340 \text { in2; NLA: } \\
1.27\end{array}$ & $\begin{array}{l}\text { Airseal plumbing penetrations, } \\
\text { ceiling tongue and groove, and } \\
\text { other unintentional openings. } \\
\text { Reduce to NLA } 0.93\end{array}$ \\
\hline Moisture testing & No moisture problems & None & None \\
\hline House insulation & $\begin{array}{l}\text { Ceiling: R-30 (RSI 5.3) minimum, R-49 (RSI 8.6) in } \\
\text { cold/severe cold climate. Floor over crawlspace:R- } 25 \\
\text { (RSI 4.4). Basement walls: R10 (RSI 1.8), Basement } \\
\text { Floor or slab usually depends on local codes. Walls: } \\
\text { Cavity should be completely filled with insulation. }\end{array}$ & $\begin{array}{l}\text { Attic: unknown - no } \\
\text { access. Walls: R-11. } \\
\text { Crawlspace: R-11. }\end{array}$ & $\begin{array}{l}\text { Upgrade crawlspace insulation to } \\
\text { R } 25 \text {. }\end{array}$ \\
\hline Windows & $\begin{array}{l}\text { Double-glazed, low-e. Shaded in cooling dominant } \\
\text { climates }\end{array}$ & $\begin{array}{l}\text { Single pane } \\
\text { aluminum frame }\end{array}$ & Replace with double pane low e. \\
\hline Window shading & Located on south and/or west facing windows & None & Add shading to reduce solar loads \\
\hline Solar radiation control & $\begin{array}{l}\text { Radiant barrier in attic, low absorptivity roof } \\
\text { coatings }\end{array}$ & None & $\begin{array}{l}\text { Add reflective paint to roof and/or } \\
\text { sunshades for windows. }\end{array}$ \\
\hline $\begin{array}{l}\text { Wall, floor and ceiling } \\
\text { construction }\end{array}$ & Space for ducts/ vents/ insulation & $\begin{array}{l}\text { Crawlspace } \\
\text { plenty of space. }\end{array}$ & Add insulation in crawlspace. \\
\hline $\begin{array}{l}\text { Occupant survey } \\
\text { Ask occupants to report } \\
\text { problems }\end{array}$ & No problems & No problems noted & None. \\
\hline
\end{tabular}

${ }^{6} \mathrm{MERV}$ is an industry standard rating system for air filters, it stands for Minimum Efficiency Report Value determined using ASHRAE Standard 52.2 
DRAFT - DO NOT QUOTE

Table A.3. Diagnostic Checklist for Moraga House.

\begin{tabular}{|c|c|c|c|}
\hline $\begin{array}{l}\text { Measurement/ } \\
\text { Observation }\end{array}$ & Potential Target value & Actual Value & Potential Retrofit Action \\
\hline Duct leakage & $<10 \%$ of air handler flow & $\begin{array}{l}\text { Two systems: S1 } 22 \% ; \\
\text { R1 } 14 \% \text { S2 } 10 \% \text { R2 N/A }\end{array}$ & $\begin{array}{llll}\begin{array}{l}\text { Seal ducts in } \\
\text { aeroseal/tape/mastic }\end{array} & \text { system } 1: \\
\end{array}$ \\
\hline Duct insulation & $\begin{array}{l}\text { R6 (RSI 1) to R8 (RSI 1.4) for all ducts } \\
\text { outside conditioned space }\end{array}$ & R4 & Add insulation to ducts \\
\hline Air flows at registers & Compare to ACCA manual J & $\begin{array}{l}\text { Sum of supplies and } \\
\text { returns: S1 760; R1 834; } \\
\text { S2 486, R2 585. Low } \\
\text { flows in one bedroom and } \\
\text { two bathrooms. }\end{array}$ & Replace registers, open/close dampers. \\
\hline Air handler flow & $\begin{array}{l}\text { Cooling: System 1:1600; System 2: } 1000 . \\
\text { Heating: } 12.5 \mathrm{cfm} / \mathrm{kBtu} / \mathrm{h}\end{array}$ & $\begin{array}{l}\text { System 1: } 970 \mathrm{cfm} \\
\text { System 2: } 540 \mathrm{cfm}\end{array}$ & $\begin{array}{l}\text { Replace filters, fix duct restrictions, } \\
\text { change fan speed, replace fan with high } \\
\text { efficient unit. Add a second return in } \\
\text { system } 2 \text {, remove two supplies from } \\
\text { system } 1 \text { and add to system } 2 \text {. }\end{array}$ \\
\hline Filter Condition & Clean and at least MERV 6 & Dirty filter & Replace with MERV 6 or better. \\
\hline Thermostat Setting & $\begin{array}{l}\text { Heating: } 68^{\circ} \mathrm{F}\left(20^{\circ} \mathrm{C}\right) \quad \text { Cooling: } 78^{\circ} \mathrm{F} \\
\left(25^{\circ} \mathrm{C}\right)\end{array}$ & Programmable & None \\
\hline Spot ventilation & $\begin{array}{l}50 \mathrm{cfm} \text { each bathroom } \\
100 \mathrm{cfm} \text { each kitchen }\end{array}$ & $\begin{array}{l}\text { Bathrooms: } 75 \mathrm{cfm} ; 63 \\
\text { cfm; } 28 \mathrm{cfm} . \text { Kitchen } 240 \\
\text { cfm. }\end{array}$ & None \\
\hline $\begin{array}{l}\text { Spot Ventilation } \\
\text { power consumption }\end{array}$ & $\begin{array}{l}2.5 \mathrm{cfm} / \mathrm{W}(1.2 \mathrm{~L} / \mathrm{s} / \mathrm{W}) \text {. Look up in HVI } \\
\text { directory (www.hvi.org) }\end{array}$ & N/A & None \\
\hline Equipment capacity & Manual S & $\begin{array}{l}4 \text { tons on system } 1 \\
\text { nameplate. } 2.5 \text { tons on } \\
\text { system } 2 \text { nameplate. }\end{array}$ & None \\
\hline Refrigerant charge & Use superheat or subcooling tests & $\begin{array}{llr}\text { System } & 1: & \text { Actual/6 } \\
\text { Target/13 } & & \\
\text { System } & 2: & \text { Actual/6 } \\
\text { Target/11 } & & \\
\begin{array}{l}\text { Both systems } \\
\text { overcharged. }\end{array} & & \text { are } \\
\end{array}$ & Remove refrigerant \\
\hline $\begin{array}{l}\text { Age and Condition of } \\
\text { HVAC system }\end{array}$ & $\begin{array}{l}\text { Clean and undamaged. } \\
\text { Determine system age. }\end{array}$ & $\begin{array}{l}\text { System 1: } 16 \text { yrs old } \\
\text { System 2: } 7 \text { yrs old - good } \\
\text { condition }\end{array}$ & Replace system 1. \\
\hline $\begin{array}{l}\text { Location of HVAC } \\
\text { system equipment and } \\
\text { ducts }\end{array}$ & Inside conditioned space & Both systems in closets. & None \\
\hline Window $\mathrm{A} / \mathrm{C}$ units & EnergyStar compliant & None & None \\
\hline Multiple systems/zoning & $\begin{array}{l}\text { System and controls in good working order } \\
\text { and providing good comfort for occupants }\end{array}$ & $\begin{array}{l}\text { Two systems serving } \\
\text { opposite ends of house. }\end{array}$ & None \\
\hline Envelope leakage & $\begin{array}{l}\text { Normalized Leakage Area reduction of } \\
0.35\end{array}$ & ELA: 350 in2; NLA 0.69 & $\begin{array}{l}\text { Airseal plumbing penetrations, attic } \\
\text { chases, top plates, and other } \\
\text { unintentional openings. Reduce to } \\
\text { NLA } 0.34\end{array}$ \\
\hline Moisture testing & No moisture problems & None & None \\
\hline House insulation & $\begin{array}{l}\text { Ceiling: R-30 (RSI 5.3) minimum, R-49 (RSI } \\
\text { 8.6) in cold/severe cold climate. Floor over } \\
\text { crawlspace:R- } 25 \text { (RSI 4.4). Basement walls: } \\
\text { R10 (RSI 1.8), Basement Floor or slab } \\
\text { usually depends on local codes. Walls: Cavity } \\
\text { should be completely filled with insulation. }\end{array}$ & $\begin{array}{l}\text { Attic: } 5 \text { inches cellulose } \\
(\mathrm{R} 17) \text {. Walls: R-11. } \\
\text { Crawlspace: probably } \\
\text { some in the new part. }\end{array}$ & $\begin{array}{l}\text { Add at least } 6 " \text { cellulose insulation to } \\
\text { attic. Add R- } 25 \text { insulation to old } \\
\text { crawlspace if none existing. }\end{array}$ \\
\hline Windows & $\begin{array}{l}\text { Double-glazed, low-e. Shaded in cooling } \\
\text { dominant climates }\end{array}$ & Double glazed. & None \\
\hline Window shading & $\begin{array}{l}\begin{array}{l}\text { Located on south and/or west facing } \\
\text { windows }\end{array} \\
\end{array}$ & $\begin{array}{l}\begin{array}{l}\text { Shielded by trees } \\
\text { south/west }\end{array} \\
\end{array}$ & None \\
\hline Solar radiation control & $\begin{array}{l}\text { Radiant barrier in attic, low absorptivity } \\
\text { roof coatings }\end{array}$ & None & $\begin{array}{l}\text { Add reflective paint to roof and/or } \\
\text { sunshades for windows. }\end{array}$ \\
\hline $\begin{array}{l}\text { Wall, floor and ceiling } \\
\text { construction }\end{array}$ & Space for ducts/ vents/ insulation & $\begin{array}{l}\text { Attic and crawlspace have } \\
\text { space. }\end{array}$ & $\begin{array}{l}\text { Add insulation in attic. Add insulation } \\
\text { in crawlspace if needed. }\end{array}$ \\
\hline $\begin{array}{l}\text { Occupant survey } \\
\text { Ask occupants to report } \\
\text { problems }\end{array}$ & No problems & $\begin{array}{l}\text { Hard to cool the family } \\
\text { room. }\end{array}$ & $\begin{array}{l}\text { Add ducts to system } 2 \text { to go to family } \\
\text { room registers and disconnect registers } \\
\text { from system } 1 \text { to family room. }\end{array}$ \\
\hline
\end{tabular}


DRAFT - DO NOT QUOTE

Table A.4. Diagnostic Checklist for Castro Valley House.

\begin{tabular}{|c|c|c|c|}
\hline $\begin{array}{l}\text { Measurement/ } \\
\text { Observation }\end{array}$ & Potential Target value & Actual Value & $\begin{array}{l}\text { Potential Retrofit } \\
\text { Action }\end{array}$ \\
\hline Duct leakage & $<10 \%$ of air handler flow & S 9\%; R 5\% & Seal ducts: aeroseal/tape/mastic \\
\hline Duct insulation & $\begin{array}{l}\text { R6 (RSI 1) to R8 (RSI 1.4) for all ducts outside } \\
\text { conditioned space }\end{array}$ & R 4 & Add insulation to ducts \\
\hline Air flows at registers & Compare to ACCA manual J & $\begin{array}{l}\text { Sum of supplies and } \\
\text { returns: } S \text { 823; R } 940 .\end{array}$ & $\begin{array}{lll}\begin{array}{l}\text { Replace } \\
\text { dampers. }\end{array} & \text { registers, open/close } \\
\end{array}$ \\
\hline Air handler flow & $\begin{array}{l}\text { Cooling: } 1270 \text { based on nameplate. } \\
\text { Heating: } 12.5 \mathrm{cfm} / \mathrm{kBtu} / \mathrm{h}\end{array}$ & $1160 \mathrm{cfm}$ & $\begin{array}{l}\text { Replace filters, fix duct restrictions, } \\
\text { change fan speed. }\end{array}$ \\
\hline Filter Condition & Clean and at least MERV 6 & $?$ & Replace with MERV 6 or better. \\
\hline Thermostat Setting & Heating: $68^{\circ} \mathrm{F}\left(20^{\circ} \mathrm{C}\right)$ Cooling: $78^{\circ} \mathrm{F}\left(25^{\circ} \mathrm{C}\right)$ & Programmable & None \\
\hline Spot ventilation & $\begin{array}{l}50 \mathrm{cfm} \text { each bathroom } \\
100 \mathrm{cfm} \text { each kitchen }\end{array}$ & $\begin{array}{l}\text { Bathrooms: } 280 \mathrm{cfm} ; 60 \\
\mathrm{cfm} ; 30 \mathrm{cfm} \text {; Kitchen } \\
700 \mathrm{cfm}\end{array}$ & $\begin{array}{l}\text { Check that kitchen vent fan does } \\
\text { not cause furnace backdraft } \\
\text { potential. }\end{array}$ \\
\hline 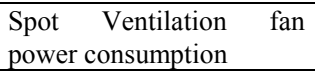 & $\begin{array}{l}2.5 \mathrm{cfm} / \mathrm{W}(1.2 \mathrm{~L} / \mathrm{s} / \mathrm{W}) \text {. Look up in } \mathrm{HVI} \\
\text { directory (www.hvi.org) }\end{array}$ & N/A & None \\
\hline Equipment capacity & Manual S: & 3.6 tons on nameplate & None \\
\hline Refrigerant charge & Use superheat or subcooling tests & $\begin{array}{l}\text { Actual superheat was } 24 \\
\text { Target superheat was } \\
11 \text {. System is severely } \\
\text { undercharged }\end{array}$ & Add refrigerant. \\
\hline $\begin{array}{l}\text { Age and Condition of } \\
\text { HVAC system }\end{array}$ & $\begin{array}{l}\text { Clean and undamaged. } \\
\text { Determine system age. }\end{array}$ & $\begin{array}{l}\text { Good condition. } 10 \\
\text { years old. }\end{array}$ & None \\
\hline $\begin{array}{l}\text { Location of } \begin{array}{l}\text { HVAC } \\
\text { system equipment } \\
\text { ducts }\end{array} \\
\end{array}$ & Inside conditioned space & Closet & None \\
\hline Window $\mathrm{A} / \mathrm{C}$ units & EnergyStar compliant & None & None \\
\hline Multiple systems/zoning & $\begin{array}{l}\text { System and controls in good working order and } \\
\text { providing good comfort for occupants }\end{array}$ & None & None \\
\hline Envelope leakage & Normalized Leakage Area reduction of 0.35 & $\begin{array}{l}\text { ELA: } 269 \text { in2; NLA } \\
1.06\end{array}$ & $\begin{array}{l}\text { Airseal plumbing penetrations, attic } \\
\text { chases, top plates, kneewall areas, } \\
\text { and other unintentional openings. } \\
\text { Reduce below NLA } 0.71\end{array}$ \\
\hline Moisture testing & No moisture problems & None & None \\
\hline House insulation & $\begin{array}{l}\text { Ceiling: R-30 (RSI 5.3) minimum, R-49 (RSI 8.6) } \\
\text { in cold/severe cold climate. Floor over } \\
\text { crawlspace:R- } 25 \text { (RSI 4.4). Basement walls: R10 } \\
\text { (RSI 1.8), Basement Floor or slab usually depends } \\
\text { on local codes. Walls: Cavity should be completely } \\
\text { filled with insulation. }\end{array}$ & $\begin{array}{l}\text { Attic: } 5 \text { inches foam (R } \\
\text { 35). Walls: R-19. } \\
\text { Crawlspace: fiberglass. }\end{array}$ & None \\
\hline Windows & $\begin{array}{l}\text { Double-glazed, low-e. Shaded in cooling } \\
\text { dominant climates }\end{array}$ & Double glazed low e & None \\
\hline Window shading & Located on south and/or west facing windows & $\begin{array}{l}\text { Shaded by garage and } \\
\text { trees on the south and } \\
\text { east. }\end{array}$ & None \\
\hline Solar radiation control & $\begin{array}{l}\text { Radiant barrier in attic, low absorptivity roof } \\
\text { coatings }\end{array}$ & None & $\begin{array}{l}\text { Add reflective paint to roof and/or } \\
\text { sunshades for windows. }\end{array}$ \\
\hline $\begin{array}{l}\text { Wall, floor and ceiling } \\
\text { construction }\end{array}$ & Space for ducts/ vents/ insulation & $\begin{array}{l}\text { Crawlspace has space } \\
\text { for additional ducts. }\end{array}$ & None \\
\hline $\begin{array}{l}\text { Occupant survey } \\
\text { Ask occupants to report } \\
\text { problems }\end{array}$ & No problems & $\begin{array}{l}\text { Too hot in the master } \\
\text { bedroom when heating, } \\
\text { undercooled office } \\
\text { when cooling. }\end{array}$ & $\begin{array}{l}\text { Improve air flows into affected } \\
\text { rooms - reduce airflow into master } \\
\text { bedroom - add window shading to } \\
\text { office. }\end{array}$ \\
\hline
\end{tabular}




\section{DRAFT - DO NOT QUOTE}

\section{Appendix B: Long-Term Monitoring Results}

The Concord test house was monitored during the pre-retrofit period for about eight weeks from 12 July through 18 September 2002. The house envelope and HVAC system were then retrofitted. Data collection then resumed on 2 October for the post-retrofit period.

Instrumentation and data acquisition for continuous monitoring of the on-site weather conditions, HVAC system component power, and supply, return, zonal and attic conditions were installed at the test house. The continuous monitoring used a computerized data logging system (Photo B.1) to collect 24 channels of data at 10 -second intervals, which were downloaded each evening at midnight via a telephone connection to a computer at LBNL. The monitored parameters and instrumentation used are displayed in Table B.1.

The analysis was conducted using a data domain including days only when the air conditioner was in operation, which was 34 non-continuous days for the pre-retrofit period (any discontinuities between days in the presentation of the monitored data are due to the noncontinuous data domain). All data are presented in Pacific Standard Time (PST).

Due to several delays during this project we were unable to complete cooling season data postretrofit for inclusion in this report. However, we are continuing the monitoring and hope to perform a comparison between pre and post retrofit performance at a later date. 


\section{Table B.1. Monitored parameters and instrumentation.}

\section{Weather Conditions (5)}

drybulb temperature

relative humidity

insolation (total incoming solar radiation)

wind speed

wind direction

HVAC System Components (4)

compressor motor

condenser fan motor

air-handler fan motor

Refrigerant Conditions (4)

suction temperature

discharge temperature

suction pressure

discharge pressure

Supply Air Conditions (4)

temperature (single sensor after heat exchanger)

temperature (before heat exchanger/coil)

relative humidity

temperature (register)

Return Air Conditions (3)

temperature (downstairs)

temperature (plenum)

relative humidity

Zone Air Conditions (2)

temperature (downstairs)

temperature (upstairs)

Attic Air Conditions (2)

temperature

relative humidity

what do up, down, plenum mean above?
Instrumentation

aspirated thermocouple

aspirated capacitive humidity sensor

silicon photodiode pyranometer

3-cup anemometer

wind vane

power meter / current transformer

power meter / current transformer

power meter / current transformer

thermocouple

thermocouple

pressure transducer

pressure transducer

thermocouple

thermocouple

capacitive humidity sensor

thermocouple

thermocouple

thermocouple

capacitive humidity sensor

thermocouple

thermocouple

thermocouple (aspirated)

capacitive humidity sensor (aspirated)

\section{Monitored On-Site Weather Data}

The on-site weather data that were monitored include outdoor drybulb temperature and outdoor relative humidity in an aspirated tube under the roof eave (Photo B.2), total incoming solar radiation (insolation) on the roof gutter (Photo B.3), and wind speed and direction atop a fifteen foot high tower (Photo B.4). These data with the exception of wind direction and the inclusion of the calculated outdoor enthalpy are shown in Figure B.1. The outdoor temperature ranged from 12 to $40^{\circ} \mathrm{C}$ ( 54 to $104^{\circ} \mathrm{F}$ ), outdoor relative humidity from $10-80 \%$, outdoor enthalpy from $18-34 \mathrm{Btu} / \mathrm{lbm}(\mathrm{kJ} / \mathrm{kg})$, insolation peaked at $775 \mathrm{~W} / \mathrm{m}^{2}$ and wind speed peaked at $6 \mathrm{mph}$. 


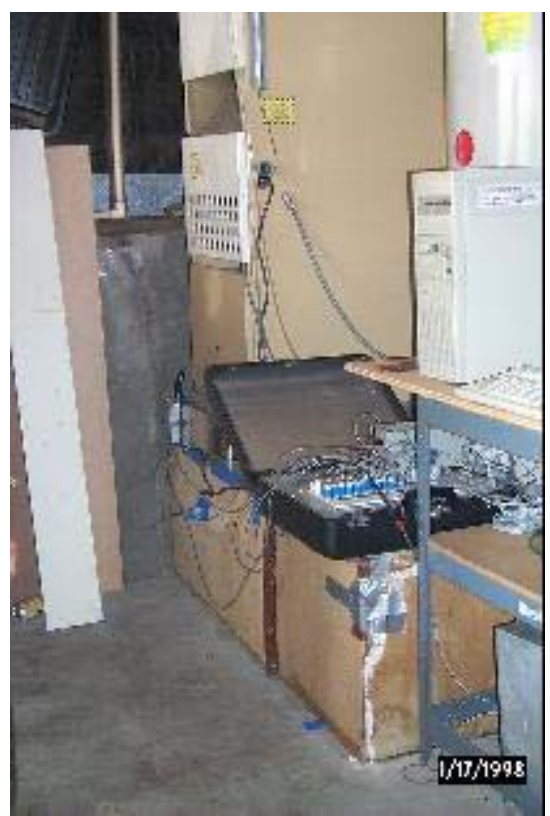

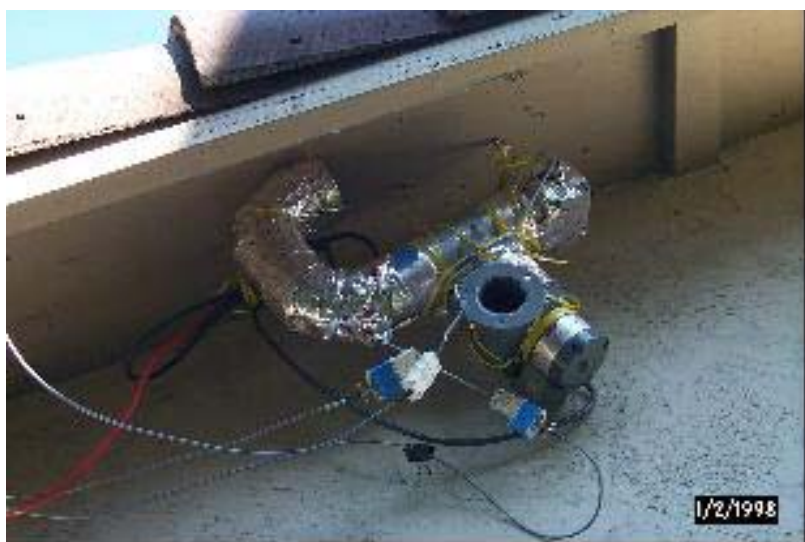

Photo B.2. Outdoor air aspirated temperature and relative humidity sensors located under roof eave.

Photo B1. Data acquisition equipment in garage with existing furnace in background.

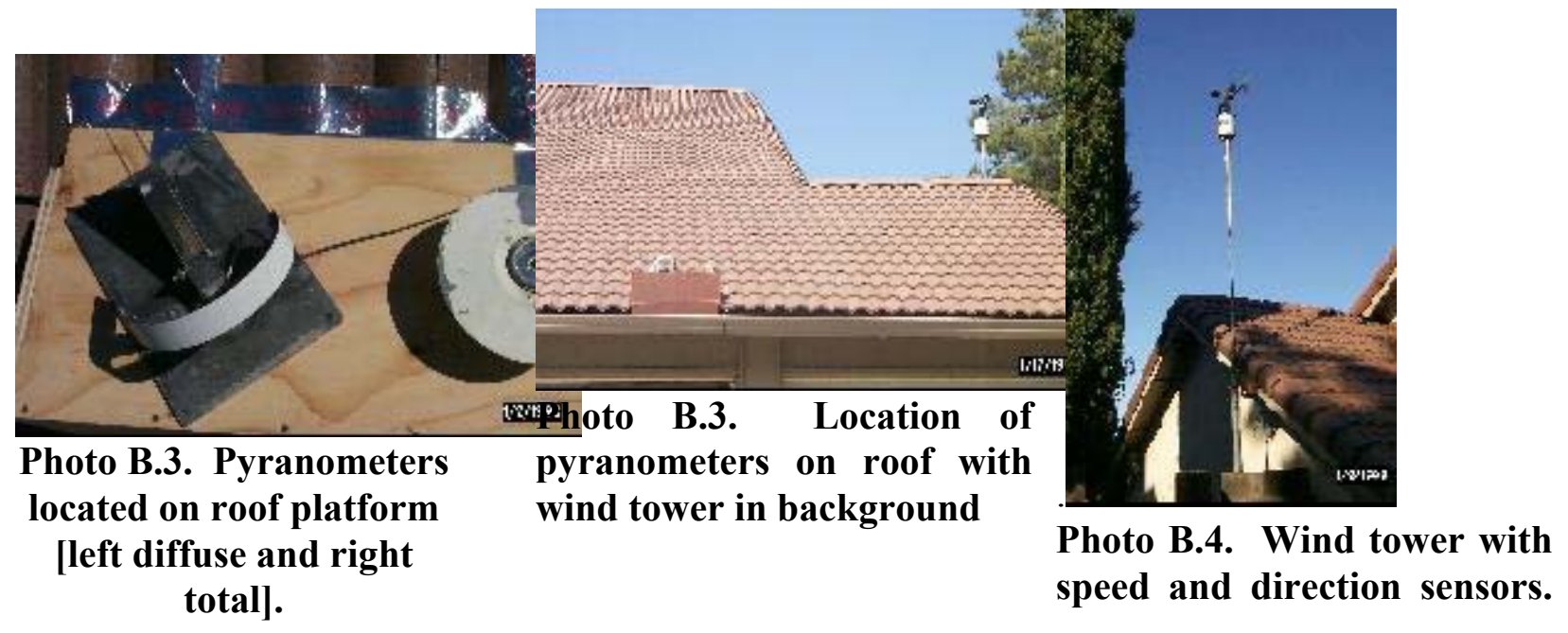


Outdoor Drybulb Temperature [C]

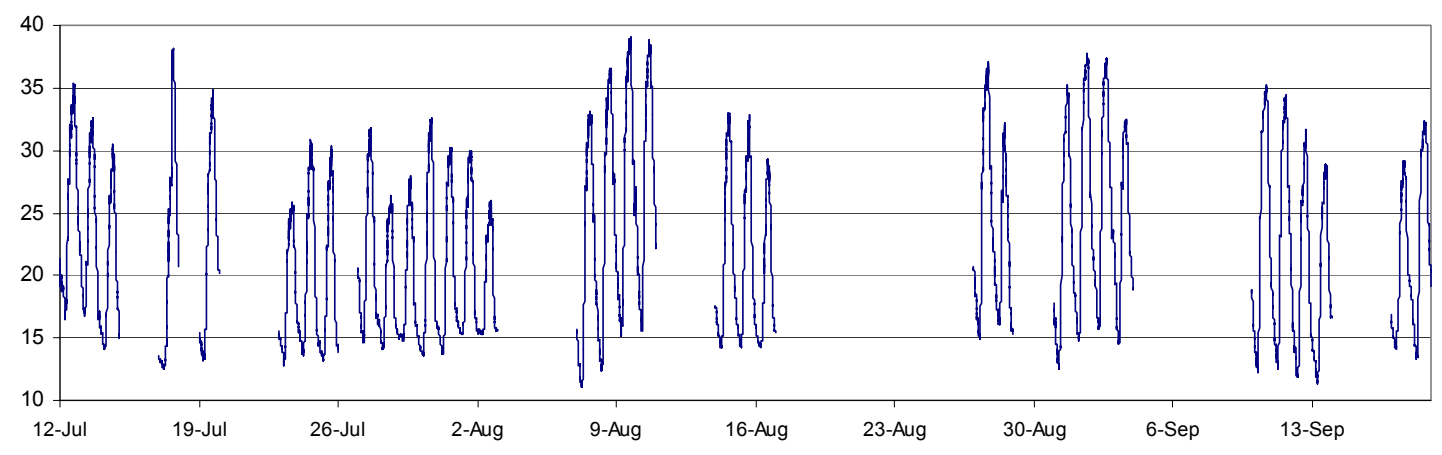

Humidity Ratio

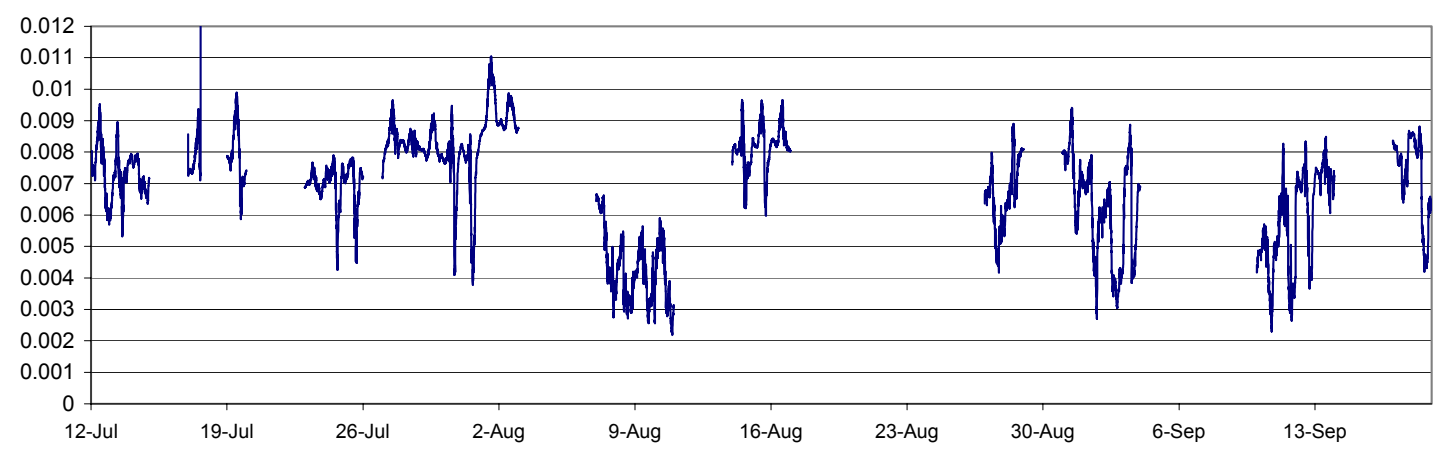

Outdoor Enthalpy [Btu/lbm]

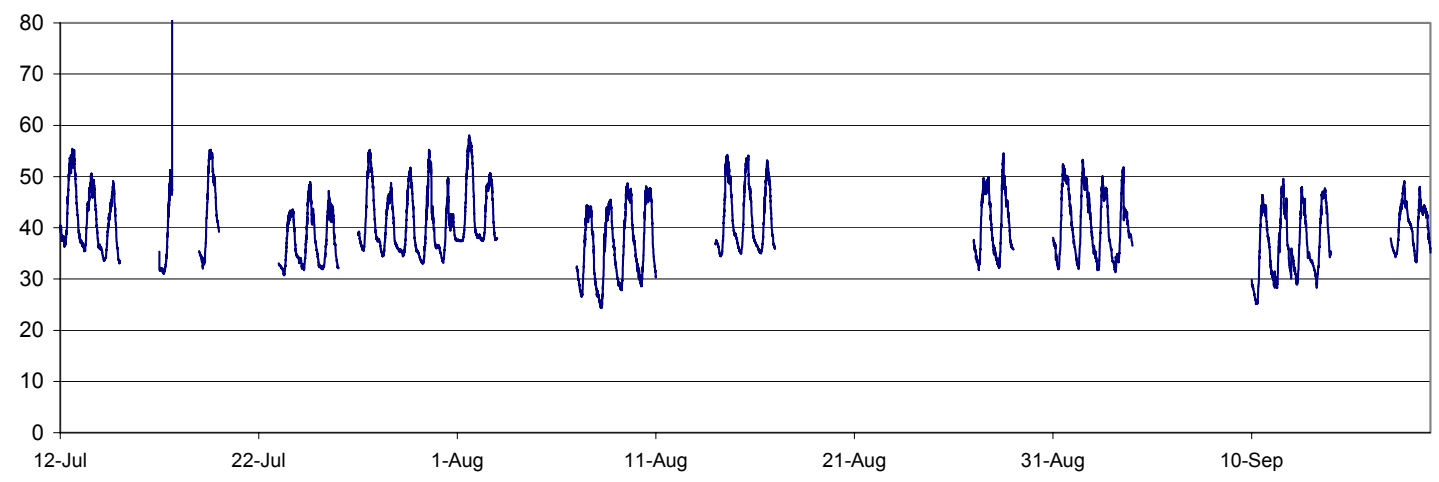

Figure B.1. Monitored 10-second on-site weather data for the $\mathbf{3 4}$ day pre-retrofit period [drybulb temperature, humidity ratio, and enthalpy]. 


\section{DRAFT - DO NOT QUOTE}

\section{Monitored HVAC System Data}

The HVAC system data that were monitored include compressor and condenser fan motors (Photo B.5), and the air-handler motor (Photo B.6). These data with the exception of vent position and the inclusion of the total air-conditioner power are shown in Figure B.2. The total AC power peaked at about $7 \mathrm{~kW}$, with the air-handler peaking at about $0.55 \mathrm{~kW}$, the condenser fan at about $0.45 \mathrm{~kW}$ and the compressor at about $6 \mathrm{~kW}$.
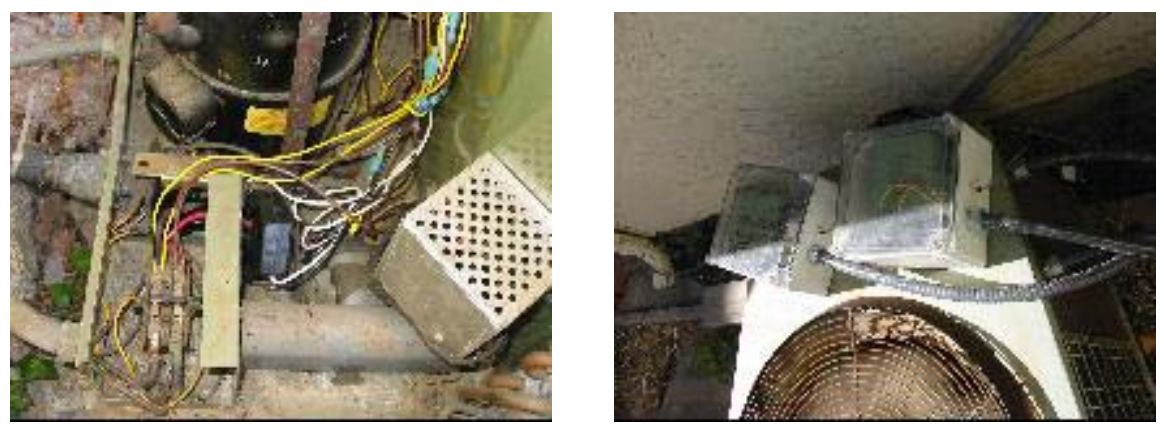

Photo B.5. AC condensing unit power meters, one each for the compressor and condensing fan motors.
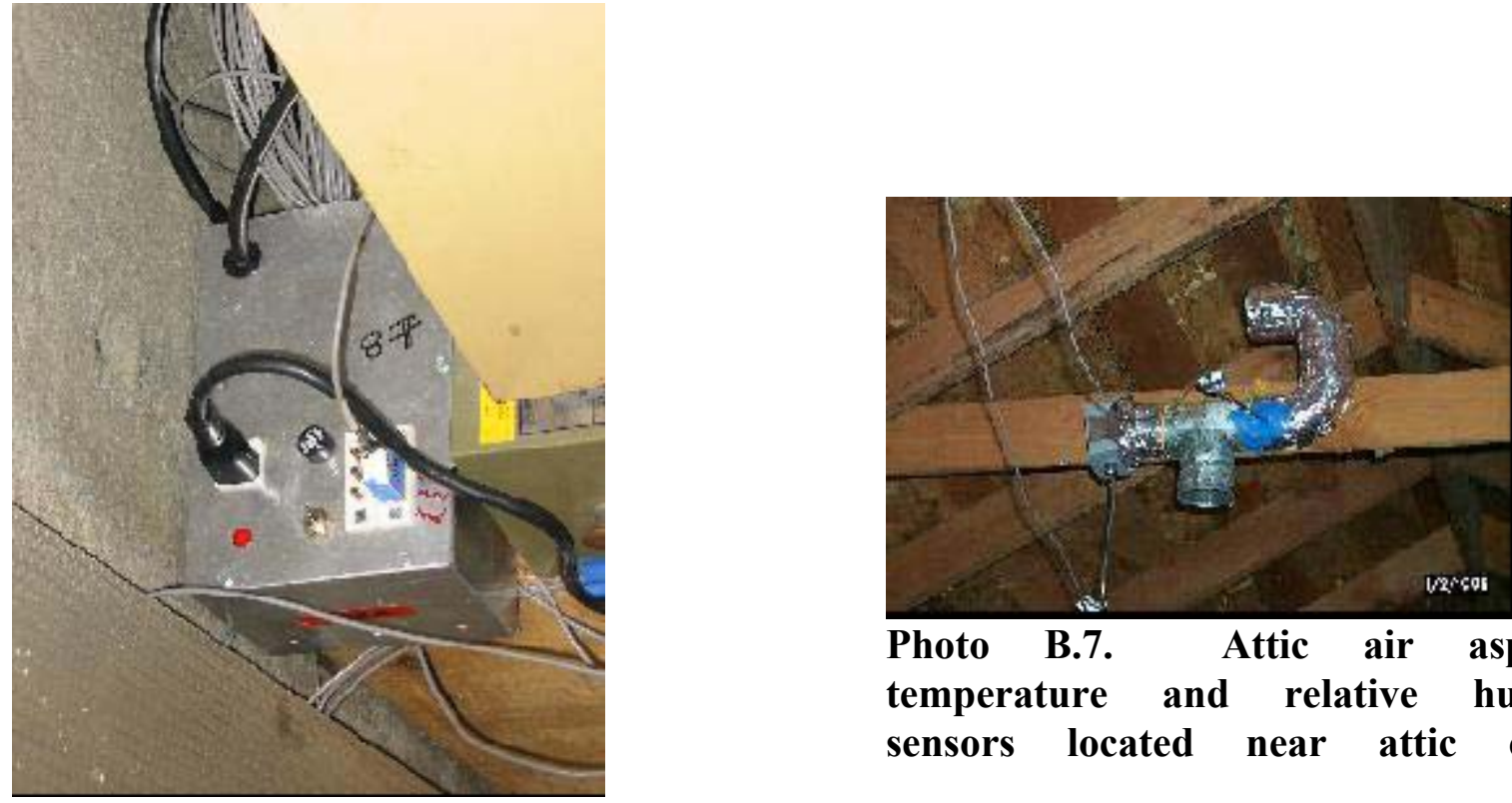

Photo B.7. Attic air aspirated temperature and relative humidity sensors located near attic ceiling.

Photo B.6. Air handler power meter located in garage. 
DRAFT - DO NOT QUOTE

Compresor Power [W]
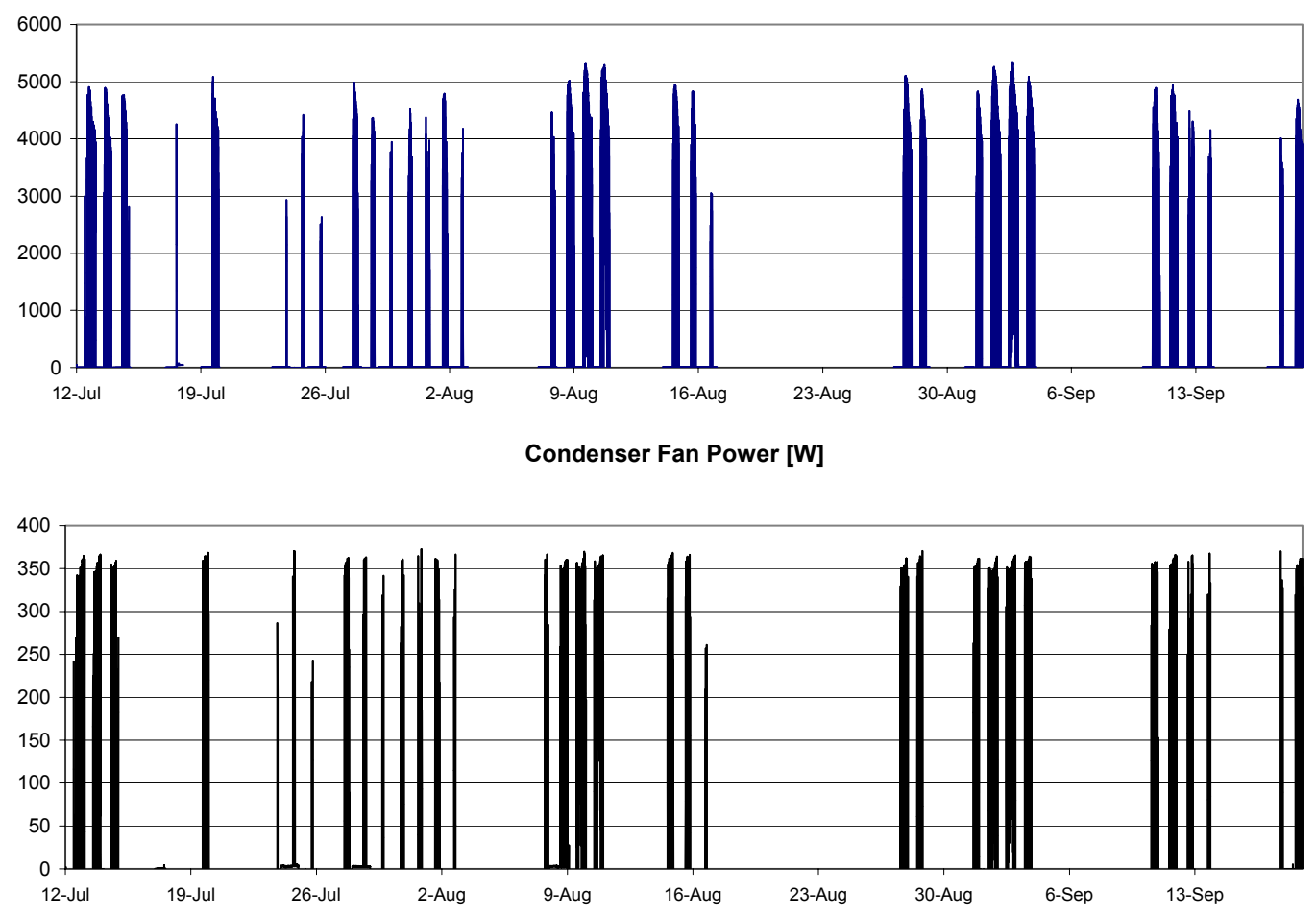

Air-Handler Power [W]
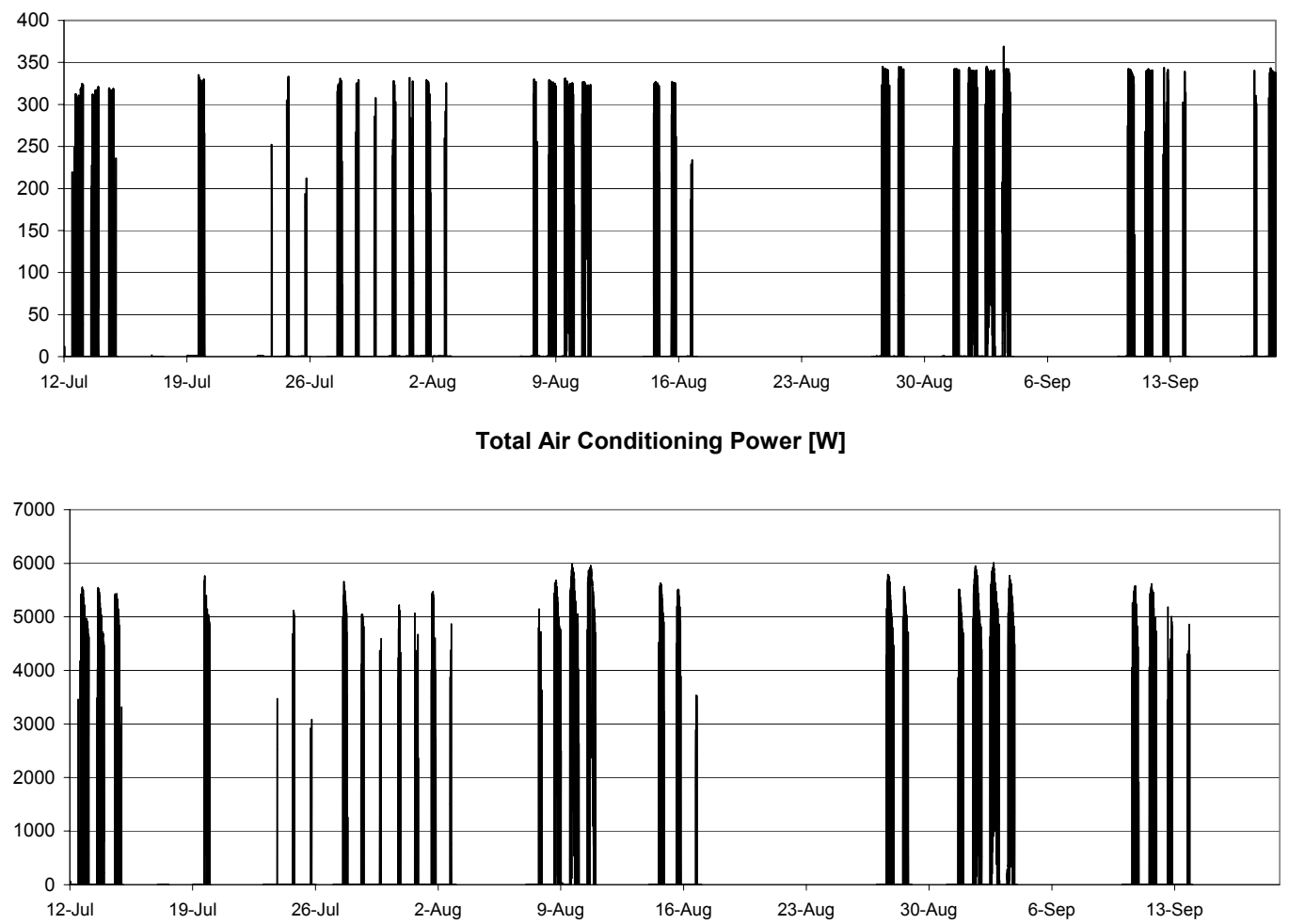

Figure B.2. Monitored 10-second air-conditioning component electricity demand data [W] 


\section{DRAFT - DO NOT QUOTE}

\section{Monitored Refrigerant Data}

The refrigerant data are discussed in the Performance of Pre-Retrofit Air-Conditioner section in this chapter and in the Refrigerant Charge section of the Diagnostics chapter.

\section{Monitored Supply and Return Air Data}

The supply and return air data that were monitored include plenum takeoffs for upstairs and downstairs drybulb temperature and downstairs relative humidity (Figure 16). These data are shown in Figure B.3. The upstairs supply air temperature operated at about $15^{\circ} \mathrm{C}$, the downstairs temperature and humidity at about $12^{\circ} \mathrm{C}$ and $70 \%$, the downstairs return air temperature operated at about $26^{\circ} \mathrm{C}$, the return plenum temperature and humidity at about $25^{\circ} \mathrm{C}$ and from $25-50 \%$. 
DRAFT - DO NOT QUOTE

Supply Air Temperature [C]

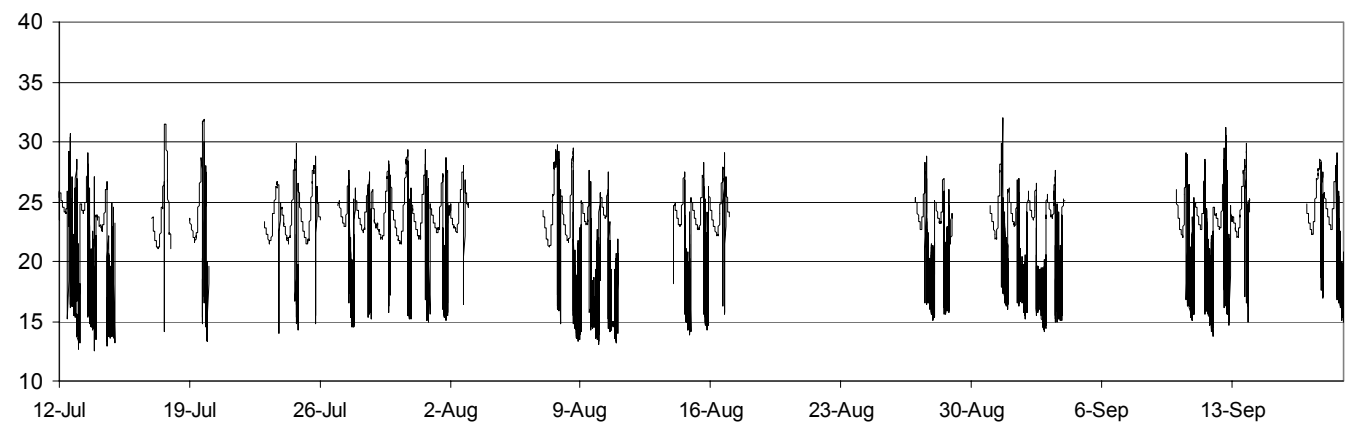

Supply Air Relative Humidity

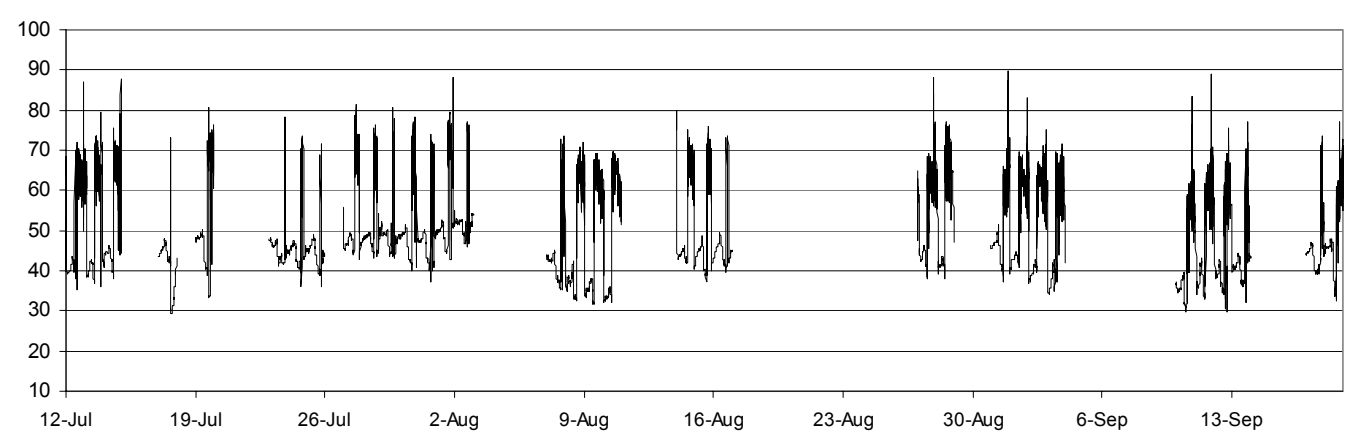

Return Air Temperature [C]
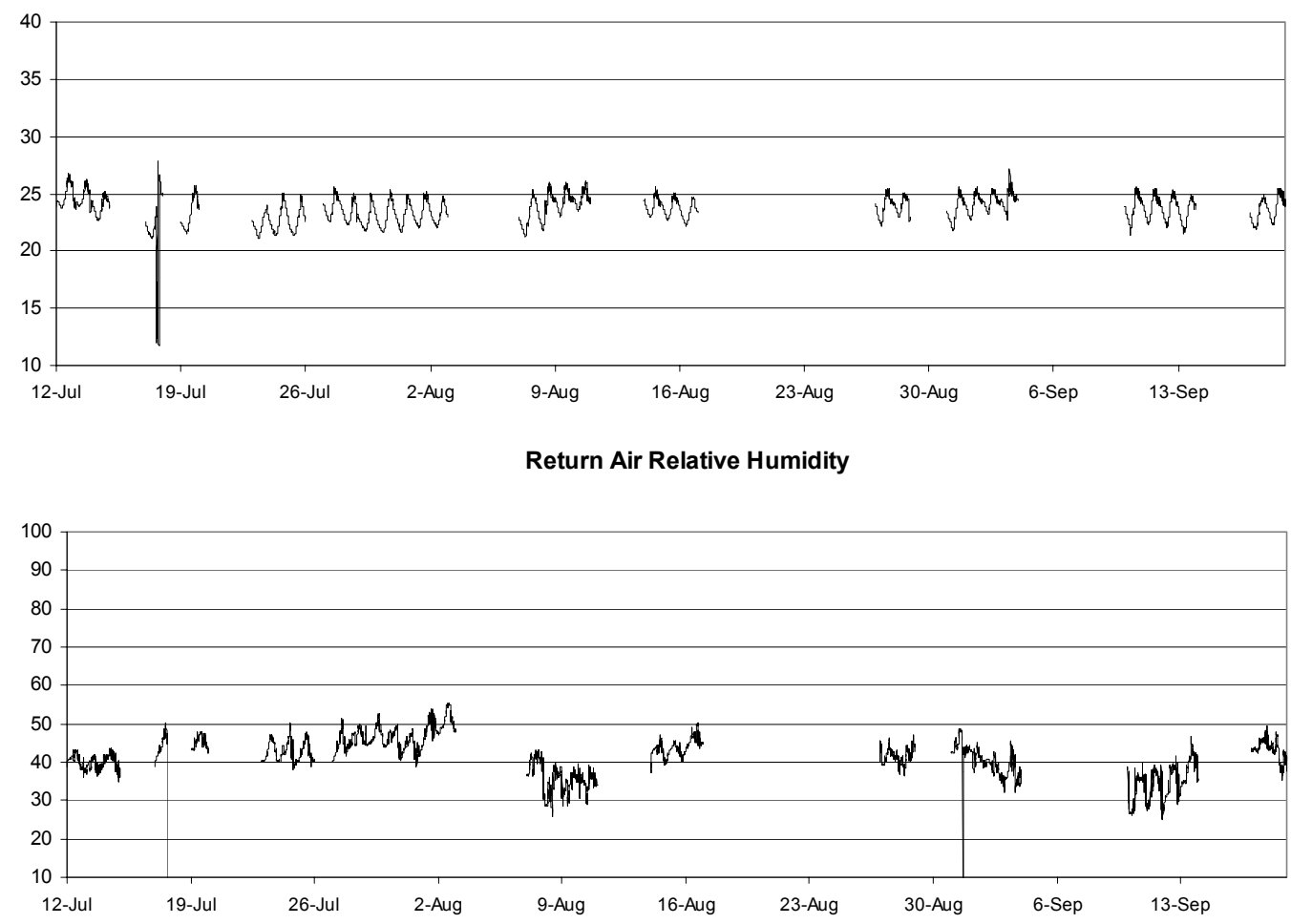

Figure B.3. 10-second supply and return data in the pre-retrofit period. 


\section{Monitored Zonal and Attic Air Data}

The zonal and attic air data that were monitored include downstairs thermostat temperature, attic temperature and attic relative humidity (Photo B.7). These data are shown in Figure B.1(e). The downstairs thermostat temperature was set at $25.5^{\circ} \mathrm{C}\left(78^{\circ} \mathrm{F}\right)$ and normally was between 23 and $26^{\circ} \mathrm{C}$. The attic air temperature ranged from $10^{\circ} \mathrm{C}$ nighttime to $58^{\circ} \mathrm{C}$ daytime, and humidity ranged from 18 to $48 \%$.
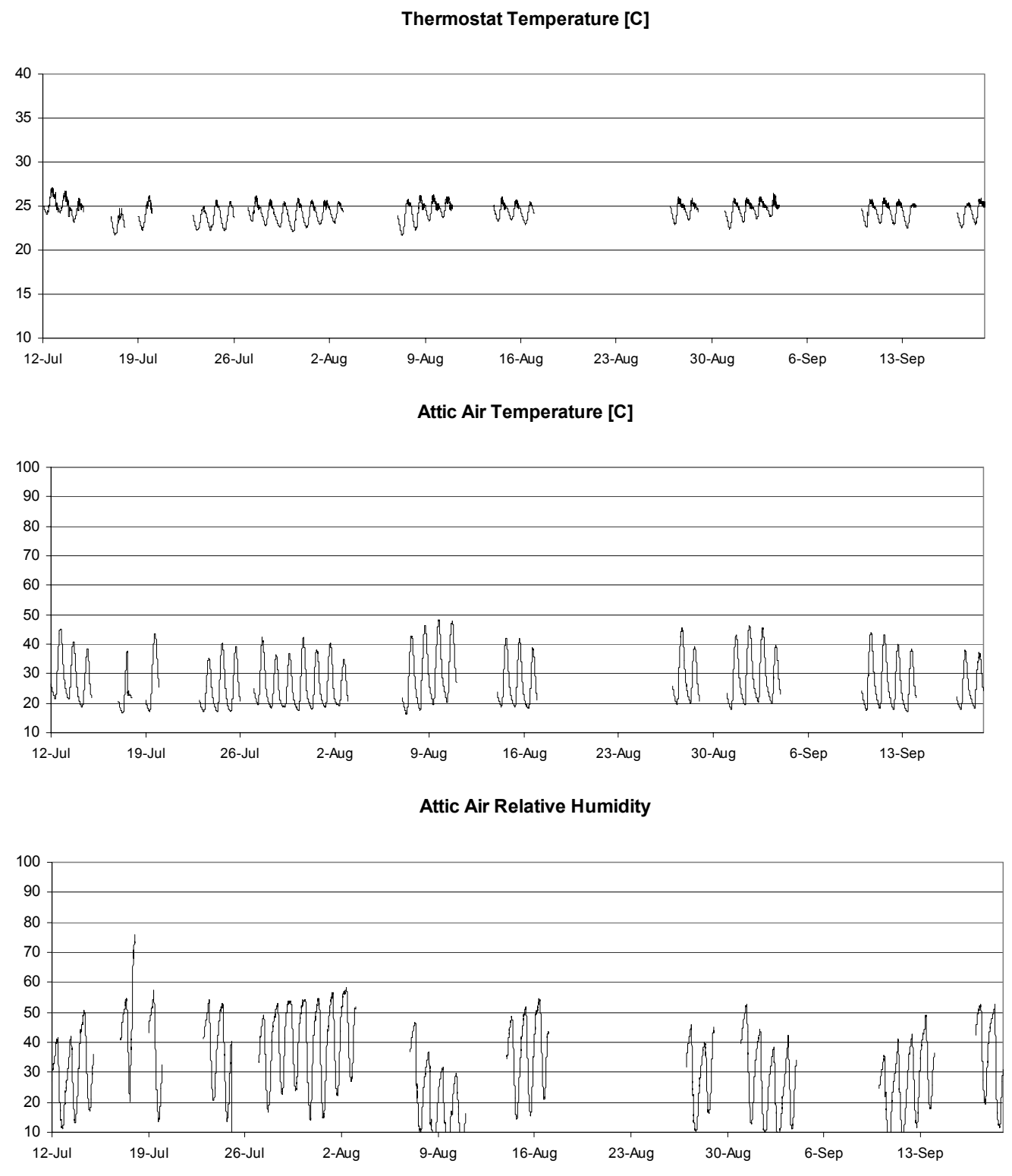

Figure B.1(e). Monitored 10-second zonal air temperatures, and attic air temperature and relative humidity data in the pre-retrofit period. 


\section{DRAFT - DO NOT QUOTE}

\section{Performance of Pre-Retrofit Air-Conditioner}

The performance of the pre-retrofit air-conditioner during the 4 hottest days of the pre-retrofit period (days 18,19, $26 \& 27$ ) is presented in this section. It includes an analysis of AC component (i.e., compressor motor, condenser fan motor and air-handler motor) power demand, calculation of operating efficiency and cooling capacity, cycling behavior and superheat.

During this 4-day period the outdoor air temperature peaked at $37.5-39.5{ }^{\circ} \mathrm{C}\left(99.5-103{ }^{\circ} \mathrm{F}\right)$ and the AC electricity consumption was highest (37.6 to 46.9 daily $\mathrm{kWh}$ ). On average for these 4 days the air-conditioner peaked at $6.6 \mathrm{~kW}$ and ran steadily at $6.0 \mathrm{~kW}$ during the hottest time of the day and at $5.0 \mathrm{~kW}$ during the cool evening hours. The transient start-up power was 500-600 $\mathrm{W}$ above steady-state operation. The AC typically drew about $5.5 \mathrm{~kW}$.

The compressor motor peaked on cycle start-up at $5.8 \mathrm{~kW}$ and settled into steady-state operation at $5.4 \mathrm{~kW}$ during the daytime and $4.2 \mathrm{~kW}$ during the evening. The transient start-up power was $400 \mathrm{~W}$ above steady-state operation. On average the compressor drew about $4.8 \mathrm{~kW}$.

The condenser fan motor occasionally peaked on cycle start-up at $400-450 \mathrm{~W}$ and settled into steady-state operation at $360 \mathrm{~W}$ during the daytime and $380 \mathrm{~W}$ during the evening. The evening time operation was $20 \mathrm{~W}$ higher than daytime because of a cooler outdoor air temperature and greater air density. The transient start-up power was 50-100 W above steady-state operation. On average the condenser fan drew about $370 \mathrm{~W}$.

The air-handler motor peaked on cycle start-up in about one-half of the cycles at 450-500 W and settled into steady-state operation at 320-340 W. The transient start-up power was 40-160 W above steady-state operation. On average the air-handler drew about $330 \mathrm{~W}$.

The operating AC energy efficiency ratio (EER) ranged from 4.2-6.0 on days 18 \& 19 and 3.65.8 on days $26 \& 27$. The operating cooling capacity ranged from $25-30 \mathrm{kBtu} / \mathrm{h}$ on days $18 \& 19$ and $21-28 \mathrm{kBtu} / \mathrm{h}$ on days $26 \& 27$. The cooling coil temperature drop ranged from $12-14{ }^{\circ} \mathrm{C}$ on days $18 \& 19$ and $10-13{ }^{\circ} \mathrm{C}$ on days $26 \& 27$. The low-end EER and capacity occurred during the hot part of the day (11am-4pm) and both increased with decreasing outdoor air temperature as the evening progressed (discussed in detail in the Dependence of AC Performance on Outdoor Air Temperature section of this chapter). The calculation method for operating EER, cooling capacity and coil temperature drop are described in Appendix $C$.

During this 4-day period the AC ran from about $11 \mathrm{am}-11 \mathrm{pm}$ (PST) and cycled on average 24.5 times. The air-conditioner exhibited a brief transient period of 50 seconds on start-up of each cycle exceeding the steady-state operating power consumption. The condenser fan and airhandler reached steady-state in 20 seconds. In an example transient the compressor peaked at $5.8 \mathrm{~kW}$ and ran steady at $5.2 \mathrm{~kW}(\Delta=600 \mathrm{~W})$, the condenser fan peaked at $410 \mathrm{~W}$ and ran steadily at $360 \mathrm{~W}(\Delta=50 \mathrm{~W})$, the air-handler peaked at $470 \mathrm{~W}$ and ran steadily at $320 \mathrm{~W}(\Delta=$ $150 \mathrm{~W})$, and the whole a/c peaked at $6.6 \mathrm{~kW}$ and ran steadily at $5.8 \mathrm{~kW}(\Delta=800 \mathrm{~W})$. For this example the operating EER, cooling capacity and coil temperature drop were $4.3,25 \mathrm{kBtu} / \mathrm{h}$ and $12.5^{\circ} \mathrm{C}$. 


\section{DRAFT - DO NOT QUOTE}

The air-conditioner superheat was calculated from a steady cycle on the hottest day with these parameters: outdoor drybulb temperature $\left[37^{\circ} \mathrm{C}\right]$, return plenum air temperature $\left[25^{\circ} \mathrm{C}\right]$, return plenum relative humidity [41\%], refrigerant suction pressure [120 psi] and refrigerant suction temperature $\left[30^{\circ} \mathrm{C}\right]$. The desired and actual superheat were $0^{\circ} \mathrm{C}$ and $16^{\circ} \mathrm{C}$ for the $\mathrm{R}-22$ refrigerant, calculated as described in the Refrigerant Charge section of the Diagnostics chapter.

The 10-second data for the 34 non-continuous days were averaged (totaled for air-conditioning data) into hourly data sets [equations 1 and 2]. The units for total hourly AC electricity use are in [Wh].

$$
\begin{aligned}
& X_{\text {avg_hour }=j}=360^{-1} \sum_{i=1}^{360} X_{i, j} \\
& {W h_{\text {total_hour }=j}}=360^{-1} \sum_{i=1}^{360} W 10 s_{i, j}
\end{aligned}
$$

The results show that AC use peaked at 5pm PST lagging behind the outdoor air temperature by one hour and peak insolation lagged behind the outdoor air temperature by three hours.

\section{Dependence of Air-Conditioner Performance on Outdoor Air Temperature}

A statistical analysis of the dependence of air-conditioning performance on outdoor air temperature was completed. Also, the relationship between attic air temperature and outdoor air temperature is examined in this section. The analysis domain included only the 4 hottest days for the 10 -second data and all 34 days for the daily data.

The 10-second data for the 34 non-continuous days were averaged for non-AC parameters [equation 3] and the hourly AC data were totaled [equation 4] into daily data sets. The units for total daily $\mathrm{AC}$ electricity use are in $[\mathrm{kWh}]$.

$$
\begin{aligned}
& X_{\text {avg_daily }}=8640^{-1} \sum_{i=1}^{8640} X_{i} \\
& k W h_{\text {total_daily }}=1000^{-1} \sum_{j=1}^{24} W h_{j}
\end{aligned}
$$

The statistical analysis firmly concluded that the outdoor drybulb air temperature was the strongest predictor of AC component electricity demand and daily consumption, as well as operating EER and cooling capacity. The single-variable regression statistics (analysis of variance, coefficients and percent standard error) for the linear relationship in equation 5 are detailed in Table B.2.

ACPerformance $=C_{0}+C_{1} *$ OUTDOOR_TEMPERATURE

Eq. 5 


\section{DRAFT - DO NOT QUOTE}

It is noticeable in these data that there are two air handler power consumption levels corresponding to two different air handler flows. We noticed that the jump in air handler power corresponded to a date on which we had been at the house. On that day we had noticed that the air handler cover panel was not properly installed, leaving a large gap in the cabinet for return leakage at a high pressure. We took care to install the panel correctly with no gap when we finished our work that day. The presence of absence of that gap could have caused a change in air handler airflow.

Examination of the 10-second data shows the total AC power increased with increasing outdoor air temperature at $69 \mathrm{~W} /{ }^{\circ} \mathrm{C}$ and likewise with compressor motor power at $70 \mathrm{~W} /{ }^{\circ} \mathrm{C}$. However, the condenser and air-handler fan power decreased with increasing outdoor air temperature at $-1.2 \&$ $-0.3 \mathrm{~W} /{ }^{\circ} \mathrm{C}$. The Energy Efficiency Ratio (EER) decreased at $-0.1 /{ }^{\circ} \mathrm{C}$ of outdoor air temperature and cooling capacity decreased at $-0.3 \mathrm{kBtu} / \mathrm{h} /{ }^{\circ} \mathrm{C}$.

The mean AC power demand in this 4-day period was $5590 \mathrm{~W}$, where the component breakdown was compressor motor $4900 \mathrm{~W}$, condenser fan motor $360 \mathrm{~W}$ and air-handler fan motor $330 \mathrm{~W}$. The mean EER and cooling capacity were 5 and $25.3 \mathrm{kBtu} / \mathrm{h}$.

Examination of the daily data reveals that total daily $\mathrm{AC}$ energy use increased at $4.7 \mathrm{kWh} /{ }^{\circ} \mathrm{C}$ of average daily outdoor air temperature. Average daily attic air temperature increased at $0.9^{\circ} \mathrm{C} /{ }^{\circ} \mathrm{C}$. 
Table B.2. Single-variable regression analysis of variance, coefficients and percent standard error of 10-second and daily air-conditioning performance versus outdoor air temperature, also, attic air temperature versus outdoor air temperature.

\begin{tabular}{|c|c|c|c|c|c|c|c|c|c|c|}
\hline \multirow{2}{*}{$\begin{array}{l}\text { Dependent } \\
\text { Variable }\end{array}$} & \multicolumn{2}{|c|}{ Data Limits } & \multicolumn{4}{|c|}{ Analysis of Variance } & \multicolumn{2}{|c|}{ Coefficients } & \multicolumn{2}{|c|}{$\%$ Error } \\
\hline & lower & upper & $\mathrm{n}$ & mean & $\sigma$ & $\mathrm{R}^{2}$ & $\mathrm{C}_{0}$ & $\overline{C_{1}}$ & $\mathrm{C}_{0}$ & $\mathrm{C}_{1}$ \\
\hline \multicolumn{11}{|l|}{ 10-Second } \\
\hline $\mathrm{AC}$ & 4500 & 6500 & 10783 & 5587 & 131 & 0.85 & 3259 & 68.5 & 0.3 & 0.4 \\
\hline Compressor & 3800 & 6000 & 10789 & 4899 & 130 & 0.85 & 2516 & 70.1 & 0.4 & 0.4 \\
\hline Cond Fan & 340 & 390 & 10756 & 358 & 3.9 & 0.68 & 400 & -1.2 & 0.1 & 0.7 \\
\hline AH Fan & 300 & 360 & 10762 & 330 & 8.4 & 0.03 & 342 & -0.3 & 0.2 & 5.3 \\
\hline Capacity & 20 & 32 & 11059 & 25.3 & 1.9 & 0.33 & 35 & -0.3 & 0.4 & 1.4 \\
\hline EER & 3 & 7 & 10424 & 5 & 0.4 & 0.68 & 9 & -0.1 & 0.3 & 0.7 \\
\hline Attic Air & 10 & 50 & 34560 & 32 & 2.6 & 0.92 & 0.86 & 1.2 & 5.8 & 0.2 \\
\hline \multicolumn{11}{|l|}{ Daily } \\
\hline $\mathrm{AC}$ & 0 & 100 & 34 & 15 & 5.3 & 0.84 & -89 & 4.7 & 9.0 & 7.6 \\
\hline Attic Air & 0 & 100 & 34 & 28 & 0.5 & 0.95 & 9 & 0.9 & 9.0 & 4.1 \\
\hline
\end{tabular}

Note: Prob $>$ f and prob $>$ T statistics for $\mathrm{C}_{0}$ and $\mathrm{C}_{1}$ were all 0.0001 .

n: Number of observations.

prob $>\mathbf{T}$. The probability of a greater absolute value for this $\mathrm{T}$ value.

prob $>\mathbf{f}$ : The probability of getting a greater $F$ statistic than that observed if the hypothesis is true. This is the significance probability.

$\sigma$ : Root Mean Square Error is an estimate of the standard deviation of the error term. It is calculated as the square root of the mean square error.

$\mathbf{R}^{2}$ : Is a measure between 0 and 1 that indicates the portion of the total variation that is attributed to the fit rather than left to residual error. It is also called the coefficient of determination and is the square of the correlation between the dependent variable and the predicted values.

standard error (SE): Standard deviation of the parameter estimate. 


\section{Appendix C. Calculation of Operating Energy Efficiency Ratio (EER) and Cooling Capacity}

$$
\begin{aligned}
& \mathrm{q}_{\text {total }}=\mathrm{q}_{\text {sensible }}+\mathrm{q}_{\text {latent }} \\
& \mathrm{q}_{\text {total }}=\rho \mathrm{Q} \Delta \mathrm{h}_{\text {total }} \\
& \Delta \mathrm{h}_{\text {total }}=\mathrm{h}_{\text {return }}-\mathrm{h}_{\text {supply }} \\
& \mathrm{q}_{\text {sensible }}=\rho \mathrm{Q} \Delta \mathrm{h}_{\text {sensible }} \\
& \Delta \mathrm{h}_{\text {sensible }}=\mathrm{C}_{\mathrm{p}} \Delta \mathrm{T} \\
& \Delta \mathrm{T}=\mathrm{T}_{\text {return }}-\mathrm{T}_{\text {supply }} \\
& \mathrm{q}_{\text {latent }}=\mathrm{q}_{\text {total }}-\mathrm{q}_{\text {sensible }} \\
& \mathrm{q}_{\text {latent }}=\rho \mathrm{Q}\left(\Delta \mathrm{h}_{\text {total }}-\Delta \mathrm{h}_{\text {sensible }}\right) \\
& \mathrm{q}_{\text {latent }}=\rho \mathrm{Q}\left(\Delta \mathrm{h}_{\text {total }}-\mathrm{C}_{\mathrm{p}} \Delta \mathrm{T}\right) \\
& \mathrm{SHR}=\mathrm{q}_{\text {sensible }} / \mathrm{q}_{\text {total }} \\
& \text { EER }=\text { cooling capacity }[\mathrm{kBtu} / \mathrm{h}] / \text { electrical input }[\mathrm{kW}] \\
& \text { COP }=\text { EER / 3.412 }
\end{aligned}
$$

\begin{tabular}{|l|l|l|l|}
\hline$\rho$ & density of air & $\mathrm{lbm} / \mathrm{ft}^{3}$ & 0.75 \\
\hline $\mathrm{C}_{\mathrm{p}}$ & specific heat of air & $\mathrm{Btu} / \mathrm{lbm}{ }^{\circ} \mathrm{F}$ & 0.24 \\
\hline $\mathrm{Q}$ & air flow rate & $\mathrm{cfm}$ & 800 \\
\hline$\Delta \mathrm{T}$ & air temperature drop & ${ }^{\circ} \mathrm{F}$ & 25 \\
\hline$\Delta \mathrm{h}_{\text {total }}$ & enthalpy change & $\mathrm{Btu} / \mathrm{lbm}$ & 8.5 \\
\hline $\mathrm{q}_{\text {sensible }}$ & $\begin{array}{l}\text { sensible cooling } \\
\text { capacity }\end{array}$ & $\mathrm{Btu} / \mathrm{h}$ & 21600 \\
\hline $\mathrm{q}_{\text {latent }}$ & latent cooling capacity & $\mathrm{Btu} / \mathrm{h}$ & 9000 \\
\hline $\mathrm{q}_{\text {total }}$ & total cooling capacity & $\mathrm{Btu} / \mathrm{h}$ & 30600 \\
\hline SHR & sensible heating ratio & dimensionless & 0.71 \\
\hline electrical input & electrical input & $\mathrm{kW}$ & 6000 \\
\hline EER & energy efficiency ratio & $\mathrm{kBtu} / \mathrm{h}$ kW & 5.1 \\
\hline COP & $\begin{array}{l}\text { coefficient of } \\
\text { performance dimensionless }\end{array}$ & 1.5 \\
\hline
\end{tabular}


Appendix D. Residential Commissioning Procedures

SUGGESTED FLOWCHART: GENERAL RESIDENTIAL COMMISSIONING

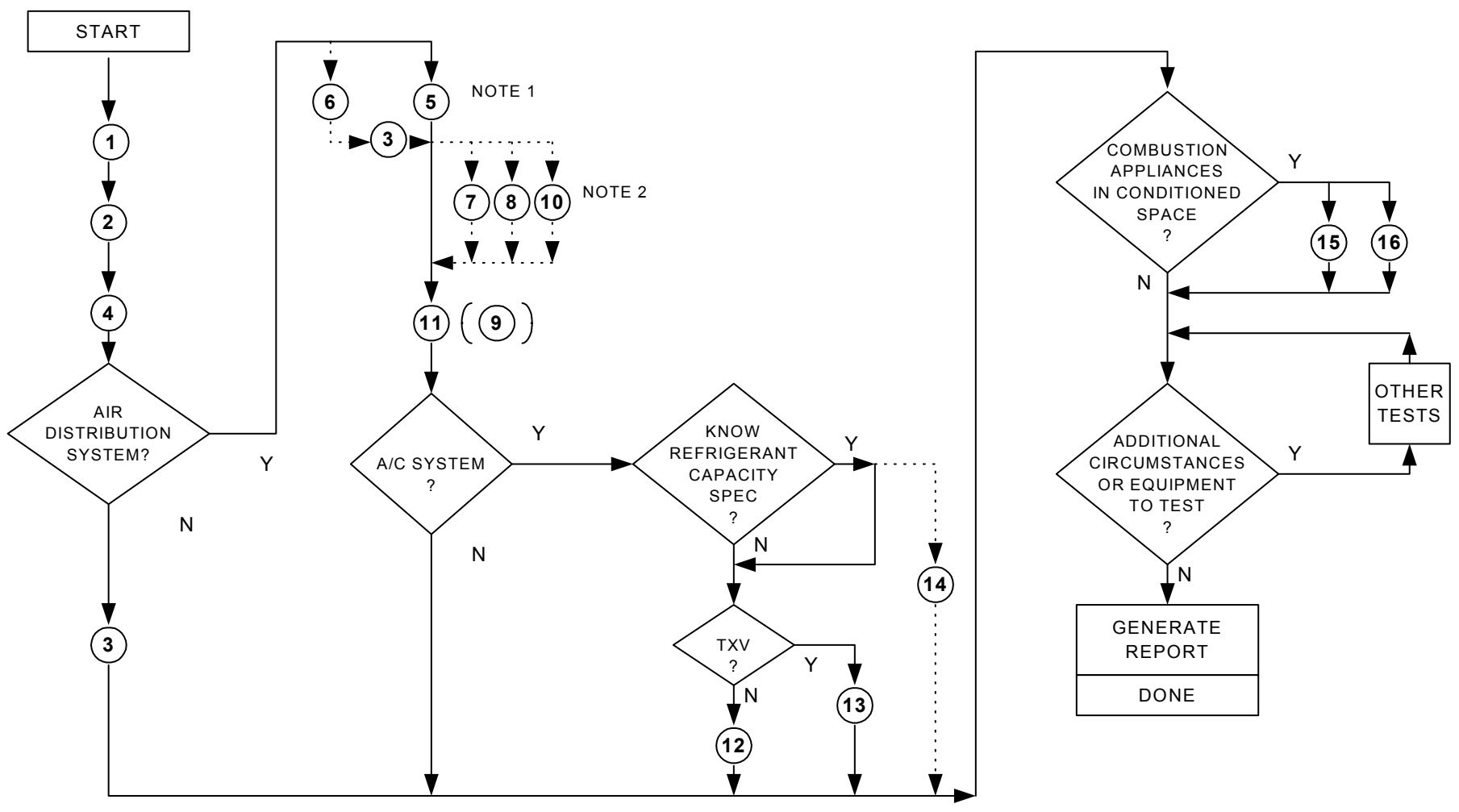

LEGEND $\longrightarrow$ RECOMMENDED METHOD

NOTE 1: (5) INCLUDES BLOWER DOOR TEST

NOTE 2: 10 NOT RECOMMENTDED

Figure D.1. Suggested flowchart for general residential commissioning. 
Table D.1. Recommended residential commissioning procedures.

\begin{tabular}{|c|c|c|c|c|c|c|}
\hline \multicolumn{2}{|c|}{ Task } & \multirow{2}{*}{$\begin{array}{l}\text { Description } \\
\text { Check that the insulation } \\
\text { installation in walls, attic and } \\
\text { floor is in accordance with } \\
\text { specifications. }\end{array}$} & \multirow{2}{*}{$\begin{array}{l}\text { Protocol } \\
\\
\text { ConSol 1999, "CIEE Final } \\
\text { Project Report: Protocols for } \\
\text { Energy Efficient Residential } \\
\text { Building Envelopes" }\end{array}$} & \multirow{2}{*}{$\begin{array}{l}\text { Equipment } \\
\text { toolbox }\end{array}$} & \multirow{2}{*}{$\begin{array}{l}\begin{array}{l}\text { Est. } \\
\text { Time }\end{array} \\
30 \\
\text { min. }\end{array}$} & \multirow{2}{*}{$\begin{array}{l}\text { Energy } \\
\text { Savings } \\
\text { Potential } \\
\text { Medium } \\
\end{array}$} \\
\hline 1 & $\begin{array}{l}\text { Insulation } \\
\text { Inspection }\end{array}$ & & & & & \\
\hline 2 & $\begin{array}{l}\text { Window } \\
\text { Inspection }\end{array}$ & $\begin{array}{l}\text { Check that the window type is } \\
\text { in accordance with } \\
\text { specifications }\end{array}$ & None in existence & $\begin{array}{l}\text { Handheld } \\
\text { spectrometer } \\
\text { (prototype } \\
\text { currently } \\
\text { available) }\end{array}$ & $\begin{array}{l}15 \\
\min .\end{array}$ & Medium \\
\hline 3 & $\begin{array}{ll}\text { Blower } & \text { Door } \\
\text { Test and } & \text { Leak } \\
\text { Detection } & \end{array}$ & $\begin{array}{l}\text { Determine the air tightness of } \\
\text { the building shell and } \\
\text { determine the location of those } \\
\text { leaks. }\end{array}$ & $\begin{array}{l}\text { ASTM E779-99 and ASTM } \\
\text { E1186-87 }\end{array}$ & $\begin{array}{l}\text { Blower Door or } \\
\text { equivalent and } \\
\text { Smoke stick }\end{array}$ & $\begin{array}{l}15- \\
45 \\
\text { min. }\end{array}$ & Medium \\
\hline 4 & Moisture Test & $\begin{array}{l}\text { Check that construction details } \\
\text { will not lead to moisture } \\
\text { problems later on. The } \\
\text { inspector must be } \\
\text { knowledgeable about common } \\
\text { moisture problems in the } \\
\text { region. }\end{array}$ & $\begin{array}{l}\text { No general standards exist. } \\
\text { Information Resource: Lstiburek } \\
\text { (1994) "Moisture Control } \\
\text { Handbook: Principles and } \\
\text { Practices for Residential and } \\
\text { Small Commercial Buildings" }\end{array}$ & $\begin{array}{l}\text { Surface scanning } \\
\text { dielectric meter }\end{array}$ & $\begin{array}{l}45 \\
\min .\end{array}$ & $\begin{array}{l}\text { Health and } \\
\text { Safety }\end{array}$ \\
\hline 5 & Delta Q Test & $\begin{array}{l}\text { Determine the building shell } \\
\text { leakage and duct leakage (at } \\
\text { operating conditions) using a } \\
\text { combined test. }\end{array}$ & $\begin{array}{l}\text { Home Energy Magazine, } \\
\text { Sept/Oct. issue, pg. } 37\end{array}$ & $\begin{array}{l}\text { Blower Door or } \\
\text { equivalent }\end{array}$ & $\begin{array}{l}30 \\
\min .\end{array}$ & High \\
\hline 6 & $\begin{array}{l}\text { Duct } \\
\text { Pressurization }\end{array}$ & $\begin{array}{l}\text { Determine the duct leakage at a } \\
\text { given pressure across the ducts. }\end{array}$ & ASTM E1554-94 & $\begin{array}{l}\text { Duct Blaster or } \\
\text { equivalent }\end{array}$ & $\begin{array}{l}45 \\
\min .\end{array}$ & High \\
\hline 7 & $\begin{array}{l}\text { AHU Airflow: } \\
\text { Fan-assisted }\end{array}$ & $\begin{array}{l}\text { Determine the airflow across } \\
\text { the air handler fan by ducting }\end{array}$ & $\begin{array}{l}\text { CEE (2000) "Specification of } \\
\text { Energy-Efficient Installation and }\end{array}$ & $\begin{array}{l}\text { Duct blaster or } \\
\text { equivalent }\end{array}$ & $\begin{array}{l}30 \\
\min .\end{array}$ & Medium \\
\hline
\end{tabular}




\begin{tabular}{|c|c|c|c|c|c|c|}
\hline & Flowmeter & $\begin{array}{l}\text { all of the flow through a } \\
\text { calibrated fan. }\end{array}$ & 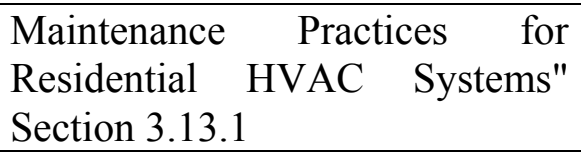 & & & \\
\hline 8 & $\begin{array}{l}\text { AHU Airflow: } \\
\text { Plate and Grid }\end{array}$ & $\begin{array}{l}\text { Determine the airflow across } \\
\text { the air handler fan by inserting } \\
\text { a calibrated flow plate into the } \\
\text { filter slot. }\end{array}$ & Manufacturer's instructions, & $\begin{array}{l}\text { Calibrated Flow } \\
\text { plate }\end{array}$ & $\begin{array}{l}15 \\
\min .\end{array}$ & Medium \\
\hline 9 & $\begin{array}{l}\text { AHU Airflow: } \\
\text { Sum-of- } \\
\text { Registers }\end{array}$ & $\begin{array}{l}\text { Determine the airflow across } \\
\text { the air handler fan by adding } \\
\text { up the duct leakage plus the } \\
\text { flow out of the registers. This } \\
\text { can be done on either the } \\
\text { supply or return side of the } \\
\text { system. }\end{array}$ & $\begin{array}{l}\text { CEE (2000) "Specification of } \\
\text { Energy-Efficient Installation and } \\
\text { Maintenance Practices for } \\
\text { Residential HVAC Systems" } \\
\text { Section 3.13.3 }\end{array}$ & $\begin{array}{l}\text { Fan assisted flow } \\
\text { hood }\end{array}$ & $\begin{array}{l}45 \\
\min .\end{array}$ & Medium \\
\hline 10 & $\begin{array}{l}\text { AHU Airflow: } \\
\text { Temperature } \\
\text { Split }\end{array}$ & $\begin{array}{l}\text { Determine the airflow across } \\
\text { the air handler fan by } \\
\text { measuring the temperatures on } \\
\text { either side of the heating } \\
\text { element, and the energy into } \\
\text { the element. }\end{array}$ & $\begin{array}{l}\text { CEE (2000) "Specification of } \\
\text { Energy-Efficient Installation and } \\
\text { Maintenance Practices for } \\
\text { Residential HVAC Systems" } \\
\text { Section 3.13.2 }\end{array}$ & $\begin{array}{l}\text { Temperature } \\
\text { sensors }\end{array}$ & $\begin{array}{l}30 \\
\min \end{array}$ & Medium \\
\hline 11 & $\begin{array}{l}\text { Register } \\
\text { Airflows }\end{array}$ & $\begin{array}{l}\text { Determine the airflow into } \\
\text { each room in order to } \\
\text { determine that the heat/ cooling } \\
\text { load of that room will be met } \\
\text { by the HVAC system }\end{array}$ & $\begin{array}{l}\text { ACCA Manual J, load } \\
\text { calculations to determine heating } \\
\text { and cooling load for each room }\end{array}$ & $\begin{array}{l}\text { Fan assisted flow } \\
\text { hood }\end{array}$ & $\begin{array}{l}45 \\
\min .\end{array}$ & Medium \\
\hline 12 & Superheat Test & $\begin{array}{l}\text { Determine the correct } \\
\text { refrigerant charge for the } \\
\text { HVAC system }\end{array}$ & $\begin{array}{l}\text { CEE (2000) "Specification of } \\
\text { Energy-Efficient Installation and } \\
\text { Maintenance Practices for } \\
\text { Residential HVAC Systems" } \\
\text { Section 3.14.1 }\end{array}$ & $\begin{array}{l}\text { Refrigerant gauge } \\
\text { set, temperature } \\
\text { sensors }\end{array}$ & $\begin{array}{l}1 \\
\text { hour }\end{array}$ & High \\
\hline 13 & Subcool Test & $\begin{array}{l}\text { Determine the correct } \\
\text { refrigerant charge for the } \\
\text { HVAC system }\end{array}$ & $\begin{array}{l}\text { CEE (2000) "Specification of } \\
\text { Energy-Efficient Installation and } \\
\text { Maintenance Practices for }\end{array}$ & $\begin{array}{l}\text { Refrigerant gauge } \\
\text { set, temperature } \\
\text { sensors }\end{array}$ & $\begin{array}{l}1 \\
\text { hour }\end{array}$ & High \\
\hline
\end{tabular}




\begin{tabular}{|c|c|c|c|c|c|c|}
\hline & & & $\begin{array}{l}\text { Residential HVAC Systems" } \\
\text { Section 3.14.2 }\end{array}$ & & & \\
\hline 14 & $\begin{array}{l}\text { Gravimetric } \\
\text { Test }\end{array}$ & $\begin{array}{l}\text { Determine the correct } \\
\text { refrigerant charge for the } \\
\text { HVAC system }\end{array}$ & $\begin{array}{l}\text { CEE (2000) "Specification of } \\
\text { Energy-Efficient Installation and } \\
\text { Maintenance Practices for } \\
\text { Residential HVAC Systems" } \\
\text { Section 3.14.4 }\end{array}$ & $\begin{array}{l}\text { Refrigerant } \\
\text { recovery } \\
\text { equipment, } \\
\text { vacuum gauge } \\
\text { vacuum pump, } \\
\text { charging scale }\end{array}$ & $\begin{array}{l}2 \\
\text { hours }\end{array}$ & High \\
\hline 15 & $\begin{array}{l}\text { House } \\
\text { Pressurization } \\
\text { Test }\end{array}$ & $\begin{array}{l}\text { Determine the magnitude of } \\
\text { the negative pressure that is } \\
\text { caused by air moving } \\
\text { appliances in a house. }\end{array}$ & $\begin{array}{l}\text { ASTM Guide E1998-99, } \\
\text { Standard Guide for Assessing } \\
\text { Depressurization-Induced } \\
\text { Backdrafting and Spillage from } \\
\text { Vented Combustion Appliances. }\end{array}$ & $\begin{array}{l}\text { Digital pressure } \\
\text { sensor }\end{array}$ & $\begin{array}{l}30 \\
\min .\end{array}$ & $\begin{array}{l}\text { Health and } \\
\text { Safety }\end{array}$ \\
\hline 16 & $\begin{array}{l}\text { Cold Vent } \\
\text { Establishment } \\
\text { Test }\end{array}$ & $\begin{array}{l}\text { Determine the maximum } \\
\text { negative pressure that a } \\
\text { combustion appliance can } \\
\text { overcome when establishing a } \\
\text { draft in a cold flue. }\end{array}$ & $\begin{array}{l}\text { ASTM Guide E1998-99, } \\
\text { Standard Guide for Assessing } \\
\text { Depressurization-Induced } \\
\text { Backdrafting and Spillage from } \\
\text { Vented Combustion Appliances. }\end{array}$ & $\begin{array}{l}\text { Blower Door or } \\
\text { equivalent }\end{array}$ & $\begin{array}{l}3 \\
\text { hours }\end{array}$ & $\begin{array}{l}\text { Health and } \\
\text { Safety }\end{array}$ \\
\hline
\end{tabular}


Table D.2. Sample commissioning report for recommended residential commissioning procedures.

The house surveyed is located in Concord, CA. It was built in 1976, and contains 2462 square feet of living space. This house is a two-story, three-bedroom, two and a half bath home. The construction is wood frame with stucco siding, a clay tile roof, and an uninsulated slab on grade foundation. Below is a chart of the tests performed at this house and a summary of the results. A visual inspection of the furnace/ air conditioner indicated that the it is a 3.5 ton, 25 year old unit in need of replacement. There is an opportunity to replace this unit with a high efficiency (90\% AFUE) furnace and 14 SEER A/C condenser equipped with TXV control. The new unit should be sized in accordance with the energy saving measures that are performed in the retrofit.

\begin{tabular}{|c|c|c|c|c|c|}
\hline $\begin{array}{l}\text { Task } \\
\#\end{array}$ & $\begin{array}{l}\text { Tuning and } \\
\text { Tweaking or } \\
\text { Opportunity }\end{array}$ & Task & Result & Recommendation & $\begin{array}{l}\text { Energy } \\
\text { Savings } \\
\text { Potentia } \\
\text { l }\end{array}$ \\
\hline 1 & $\mathrm{O}$ & $\begin{array}{l}\text { Insulation } \\
\text { Inspection }\end{array}$ & $\begin{array}{l}\text { R-26 ceiling } \\
\text { R-11 Walls } \\
\text { None Slab }\end{array}$ & Add insulation in attic to bring it up to nominal R-38 & Medium \\
\hline 2 & $\mathrm{O}$ & $\begin{array}{l}\text { Window } \\
\text { Inspection }\end{array}$ & $\begin{array}{l}\text { Single pane sliding } \\
\text { windows, metal frame }\end{array}$ & $\begin{array}{l}\text { Upgrade to double paned, low-e low solar gain, } \\
\text { fiberglass or vinyl frame windows }\end{array}$ & Medium \\
\hline 3 & $\mathrm{~T} \& \mathrm{~T}$ & $\begin{array}{ll}\text { Blower } & \text { Door } \\
\text { Test and } & \text { Leak } \\
\text { Detection } & \end{array}$ & $\begin{array}{l}\text { NL }=0.97, \text { ELA }=278 \\
\text { in }^{2} . \text { Major leak sites } \\
\text { were found between the } \\
\text { attic and living spaces. }\end{array}$ & $\begin{array}{l}\text { Seal building shell, but no tighter than NL }=0.49 \\
\text { Seal mechanical and plumbing chases in attic. Seal } \\
\text { top of stairwell walls in attic. Improve attic hatch } \\
\text { weatherstripping. Seal plumbing penetrations in } \\
\text { kitchen and bathrooms. }\end{array}$ & Medium \\
\hline 5 & $\mathrm{~T} \& \mathrm{~T}$ & Delta Q test & $\begin{array}{l}\text { Qs }=145 \quad \mathrm{cfm}, \quad \mathrm{Qr}=408 \\
\mathrm{cfm}\end{array}$ & $\begin{array}{l}\text { Seal supply ductwork. Install new return duct } \\
\text { because the location of the existing duct does not } \\
\text { allow access for sealing. }\end{array}$ & High \\
\hline 6 & $\mathrm{~T} \& \mathrm{~T}$ & $\begin{array}{l}\text { Duct } \\
\text { Pressurization }\end{array}$ & $\begin{array}{l}\text { Qs=86 } \mathrm{cfm}_{25}, \quad \mathrm{Qr}=786 \\
\mathrm{cfm}_{25}\end{array}$ & Same as Delta Q test & High \\
\hline 7 & $\mathrm{~T} \& \mathrm{~T}$ & $\begin{array}{l}\text { AHU Airflow: } \\
\text { Fan-assisted } \\
\text { Flowmeter } \\
\end{array}$ & $804 \mathrm{cfm}$ & Increase airflow to $1200 \mathrm{cfm}$ & Medium \\
\hline 8 & $\mathrm{~T} \& \mathrm{~T}$ & $\begin{array}{l}\text { AHU Airflow: } \\
\text { Sum-of- }\end{array}$ & $779 \mathrm{cfm}$ & Increase airflow to $1200 \mathrm{cfm}$ & Medium \\
\hline
\end{tabular}




\begin{tabular}{|l|l|l|l|l|l|}
\hline & & Registers & & \\
\hline 11 & T \& T & $\begin{array}{l}\text { Register } \\
\text { Airflows }\end{array}$ & $\begin{array}{l}\text { Refer to register flow } \\
\text { chart for measured } \\
\text { values. }\end{array}$ & $\begin{array}{l}\text { Dining room airflow is 30\% low, master bedroom } \\
\text { airflow is 55\% low, other bedrooms and bathrooms } \\
\text { are slightly high. Adjust dampers to improve } \\
\text { comfort. }\end{array}$ & \begin{tabular}{l} 
Add refrigerant charge \\
\hline 12
\end{tabular} \\
\hline
\end{tabular}




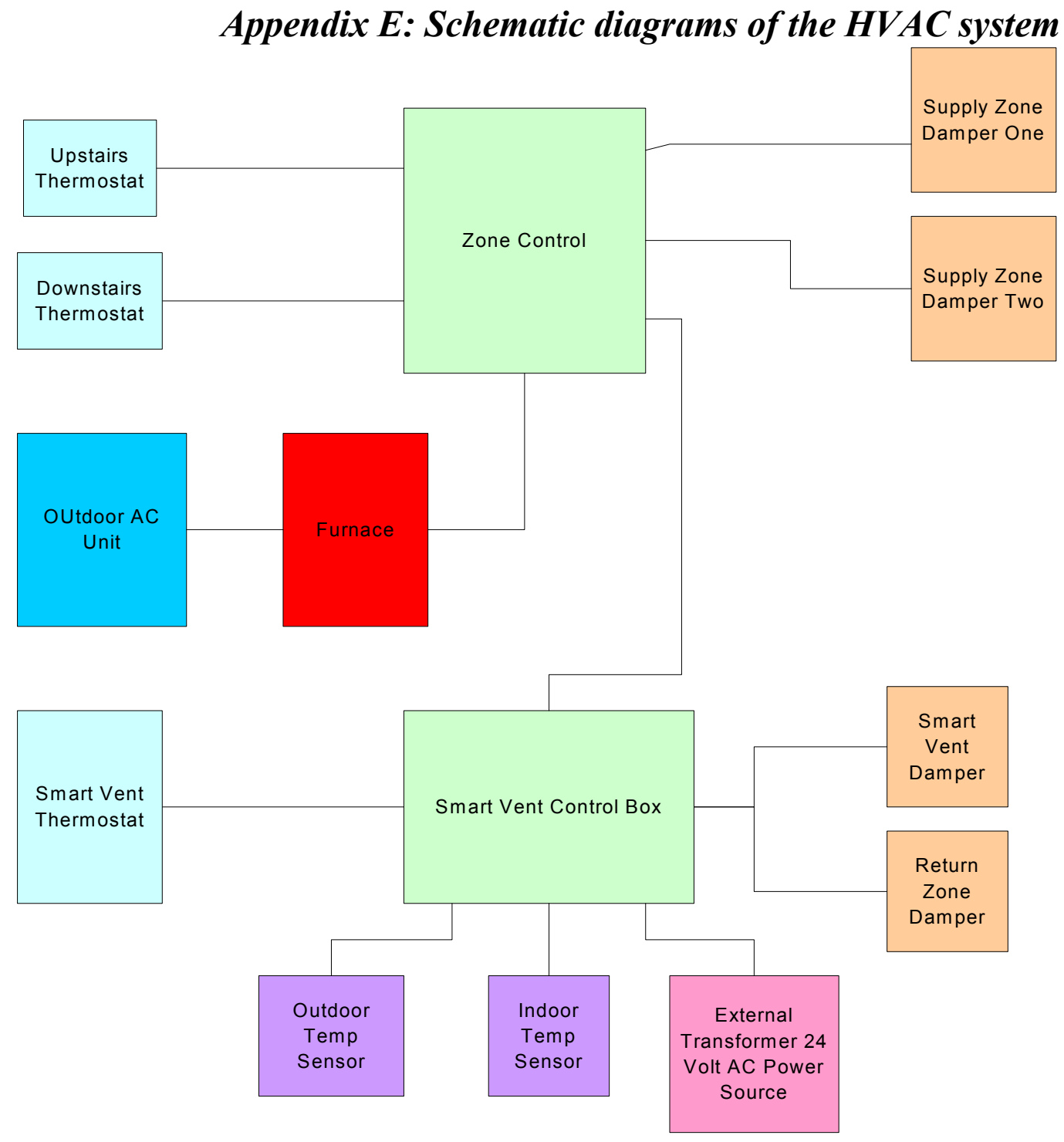

Figure 18(a). Simplified wiring diagram for the HVAC equipment at the case study house. 


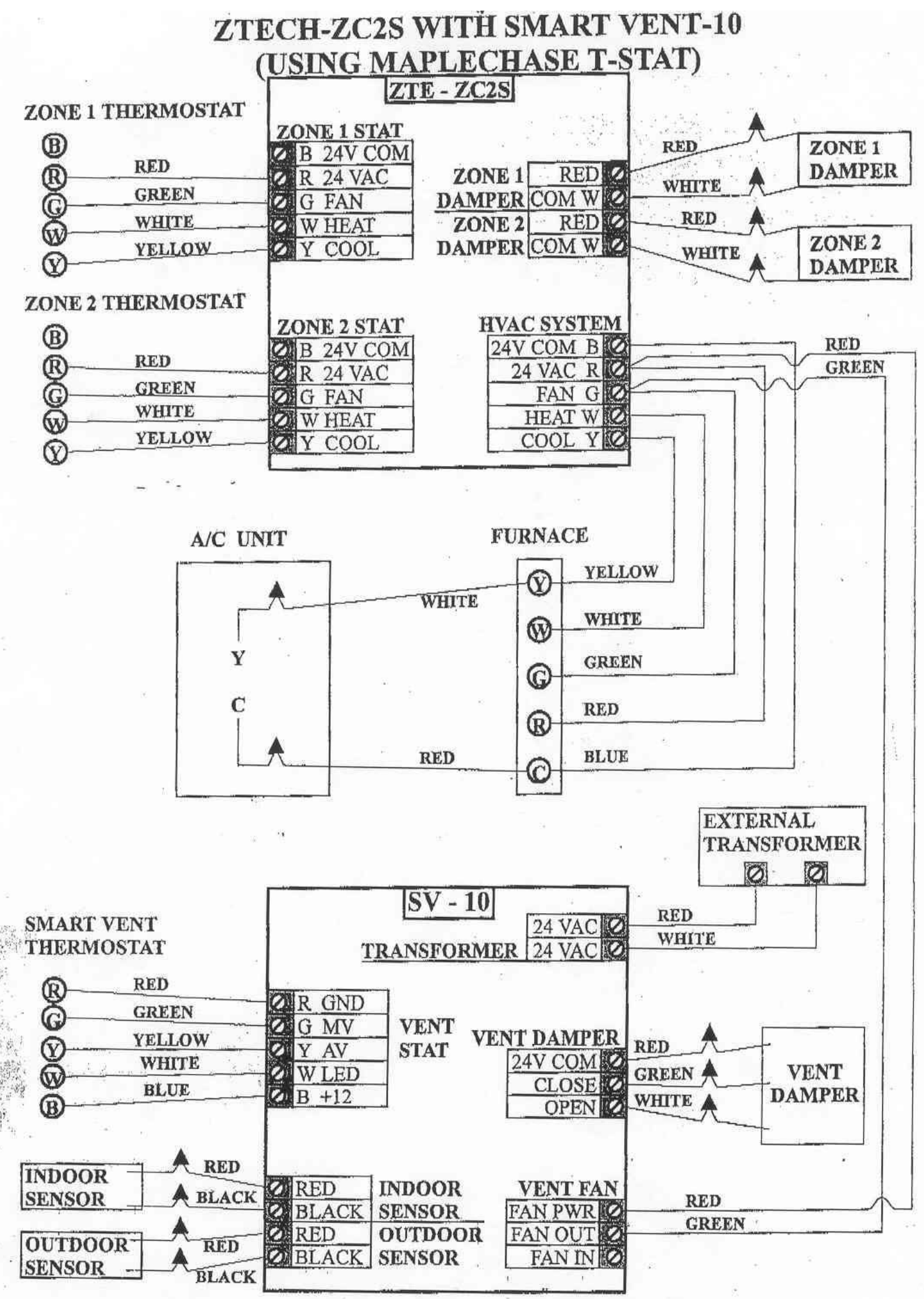

Figure 18(b). Detailed wiring diagram for the HVAC equipment at the case study test house. 


\section{Appendix F. Retrofit material and labor costs billed by the HVAC contractor.}

\begin{tabular}{|c|c|c|c|}
\hline Quantity & Description & Cost & $\begin{array}{c}\text { Extended } \\
\text { Cost }\end{array}$ \\
\hline 1 & 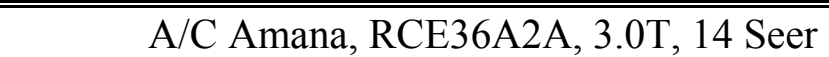 & $\$$ & $\$$ \\
\hline 16 & A/C, Line Set, Cover & $\$ 10.78$ & $\$ 172.48$ \\
\hline 1 & A/C, Slabs, 36"x36"x3", Clad Lite & $\$ 39.59$ & $\$ 39.59$ \\
\hline 50 & A/C. Line Set, 7/8" & $\$ 2.16$ & $\$ 108.00$ \\
\hline 1 & Breaker, Disconnect, 60AMP & $\$ 34.46$ & $\$ 34.46$ \\
\hline 1 & Coil, Aspen BBL48-X2nF, 4.0T, Horz. & $\$ 339.33$ & $\$ 339.33$ \\
\hline 3 & Collar, Duct Board, 10", 06" High & $\$ 2.22$ & $\$ 6.66$ \\
\hline 2 & Collar, Duct Board, 12", 06" High & $\$ 2.67$ & $\$ 5.34$ \\
\hline 2 & Collar, Duct Board, 18", 06" High & $\$ 3.92$ & $\$ 7.84$ \\
\hline 2 & Collar, Duct Board, 4", 06" High & $\$ 1.01$ & $\$ 2.02$ \\
\hline 3 & Collar, Duct Board, 5", 06" High & $\$ 1.23$ & $\$ 3.69$ \\
\hline 4 & Collar, Duct Board, 7", 06" High & $\$ 1.68$ & $\$ 6.72$ \\
\hline 5 & Collar, Duct Board, 8", 06" High & $\$ 1.83$ & $\$ 9.15$ \\
\hline 3 & Collar, Duct Board, 9", 06" High & $\$ 2.07$ & $\$ 6.21$ \\
\hline 1 & Collar, S/M, Start, 08", 28GA, G90 & $\$ 1.62$ & $\$ 1.62$ \\
\hline 1 & Collar, S/M, Start, 10", 28GA, G90 & $\$ 2.11$ & $\$ 2.11$ \\
\hline 1 & Collar, S/M, Start, 18", 28GA, G90 & $\$ 3.77$ & $\$ 3.77$ \\
\hline 1 & Condensate, Beutler, Pan, Std. 33"x64" & $\$ 20.09$ & $\$ 20.09$ \\
\hline 1 & Damper, Motorized, 08", RDNO & $\$ 46.07$ & $\$ 46.07$ \\
\hline 1 & Damper, Motorized, 10", RDNO & $\$ 30.17$ & $\$ 30.17$ \\
\hline 400 & Duct, Strap, 01 1/2", $30 \mathrm{Ga}$, no holes & $\$ 0.09$ & $\$ 36.00$ \\
\hline 2 & Elbow, Hard, 3"x90Deg, Adj, 26Ga. & $\$ 1.55$ & $\$ 3.10$ \\
\hline 10 & Electrical, Connector, Madison, 1/2" & $\$ 0.13$ & $\$ 1.30$ \\
\hline 10 & Electrical, Connector, Madison, 3/4" & $\$ 0.09$ & $\$ 0.90$ \\
\hline 4 & Electrical, Connector, Romex, 1/2" & $\$ 0.22$ & $\$ 0.88$ \\
\hline 2 & Electrical, Handy Box, 04"x04", N/Brackets & $\$ 1.14$ & $\$ 2.28$ \\
\hline 1 & Electrical, Handy Box, Octagon, 3 1/2" & $\$ 2.31$ & $\$ 2.31$ \\
\hline 3 & $\begin{array}{r}\text { Electrical, Handy Box, SN-18, 02"x04", Plastic, } \\
\text { Nail On }\end{array}$ & $\$ 0.67$ & $\$ 2.01$ \\
\hline 1 & Electrical, Keyless Lampholder & $\$ 2.76$ & $\$ 2.76$ \\
\hline 1 & Electrical, Pigtail, 06FT & $\$ 4.37$ & $\$ 4.37$ \\
\hline 1 & $\begin{array}{r}\text { Electrical, Receptical, 04"x04", Cover, Blank, } \\
\text { MTL }\end{array}$ & $\$ 0.58$ & $\$ 0.58$ \\
\hline 2 & Electrical, Receptical, Outlet, DBL, GFI & $\$ 16.57$ & $\$ 33.14$ \\
\hline 4 & Electrical, Rough Service Bulbs & $\$ 0.97$ & $\$ 3.88$ \\
\hline 80 & Fastener, Panduit, Black, 36", UV Stabilized & $\$ 0.22$ & $\$ 17.60$ \\
\hline 25 & Flex, R-4, 04"x50FT & $\$ 0.73$ & $\$ 18.25$ \\
\hline 25 & Flex, R-4, 05"x50FT & $\$ 0.86$ & $\$ 21.50$ \\
\hline 50 & Flex, R-4, 07"x50FT & $\$ 1.03$ & $\$ 51.50$ \\
\hline 100 & Flex, R-4, 08"x50FT & $\$ 1.14$ & $\$ 114.00$ \\
\hline
\end{tabular}


Pipe, Black Iron, Nipple, 1/2"x02"

$\$ 0.43$

Pipe, Black Iron, Nipple, 1/2"x03"

$\$ 0.50$

Pipe, Black Iron, Nipple, 1/2"x04"

$\$ 0.58$

Pipe, Black Iron, Nipple, 1/2"x05"

$\$ 0.67$

Pipe, Black Iron, Nipple, 1/2"x06" Pipe, Black Iron, Tee, 1/2"

$\$ 1,644.72$

$\$ 13.24$

$\$ 53.00$

$\$ 53.00$

$\$ 110.88$

$\$ 3.52$

$\$ 8.66$

$\$ 23.20$

$\$ 23.20$

$\$ 0.05$

$\$ 3.36$

$\$ 2.35$

$\$ 0.39$

$\$ 0.43$

$\$ 0.50$

$\$ 0.58$

$\$ 1.34$

$\$ 0.65$

$\$ 1.82$

$\$ 0.65$

Pipe, Conductor, 03", 26GA, G60

$\$ 0.95$

Pipe, Gas Flex, 1/2"x18" I.D, W/Valve

$\$ 22.07$

$\$ 0.95$

Pipe, PVC, 02"x10FT, SCH40

$\$ 1.25$

$\$ 22.07$

Pipe, PVC, 3/4"x10FT, SCH40

$\$ 0.45$

Pipe, PVC, Adapter, 1/2", FPT

$\$ 0.26$

Pipe, PVC, Adapter, 1/2", MPT

$\$ 0.28$

Pipe, PVC, Adapter, 3/4" FPT

$\$ 0.37$

Pipe, PVC, Adapter, 3/4" MPT

$\$ 0.26$

Pipe, PVC, Cap, 3/4", Slip

$\$ 0.26$

Pipe, PVC, Coupling, 02", Slip

$\$ 0.91$

Pipe, PVC, Elbow, 02"x90Deg, Slip

$\$ 1.49$

$\$ 12.50$

$\$ 27.00$

$\$ 0.26$

$\$ 0.28$

$\$ 0.37$

$\$ 0.26$

$\$ 0.26$

$\$ 1.82$

$\$ 5.96$

Pipe, PVC, Elbow, 3/4"x45Deg, Slip

$\$ 0.65$

$\$ 3.25$

Pipe, PVC, Elbow, 3/4"x90Deg, Slip

$\$ 0.28$

$\$ 1.40$

Pipe, PVC, P-Trap, 3/4", Slip

$\$ 1.16$

$\$ 1.16$ Pipe, PVC, Tee, 02", SxSxT

Pipe, PVC, Tee, 3/4" SxSxS

Pipe, Strap, Metal, BRC, 02 Hole, 1/2"

$\$ 0.37$

$\$ 0.37$

$\$ 0.09$

$\$ 0.90$

$\$ 0.13$

$\$ 0.13$

$\$ 5.39$

$\$ 5.39$

$\$ 0.19$

$\$ 0.38$

$\$ 0.37$

$\$ 0.74$

Plenum, T5, 17"x17"x17"

$\$ 172.40$

$\$ 172.40$ 
Reg, Return, 170FF, Filter Fram. 30"x20"

$\$ 35.90$

$\$ 19.27$

Roof Jack, Base, Oatey, Galv, Comp, 03"

$\$ 5.34$

Sealant, Hardcast, Cascoat

$\$ 20.69$

Smart Vent, Barometric Relief Valve

$\$ 21.44$

Smart Vent, Control, SV10

$\$ 156.04$

$\$ 35.90$

$\$ 5.34$

$\$ 41.38$

$\$ 21.44$

Smart Vent, Damper, Diversion, 20"x30"

$\$ 39.48$

$\$ 156.04$

Smart Vent, Sensor, Inside, RS2

$\$ 30.64$

$\$ 39.48$

$\$ 30.64$

Smart Vent, Sensor, Outside, RS3

$\$ 39.01$

$\$ 5.00$

$\$ 39.01$

Tape, Sheet Metal, Duct 1 1/2", 32RL/CS

$\$ 2.24$

$\$ 5.00$

Taper, 1-Piece, Cone, 04" to 03", 28GA, G90

$\$ 2.31$

$\$ 2.24$

$\$ 2.31$

$\$ 69.65$

Thermostat, Smart Vent, VS2

$\$ 3.79$

$\$ 69.65$

Tools, Blade, Sawzall, Metal, 06"

$\$ 4.46$

$\$ 7.58$

Tools, Blade, Sawzall, Wood, 6"

$\$ 75.72$

$\$ 8.92$

Vent, Dormer, Smart Vent, Tile, 18"

$\$ 47.02$

$\$ 75.72$

Wire, Thermostat, 18/8

$\$ 20.93$

$\$ 47.02$

ZTE Material,Transformer, XP2420, 24VAC/20VA

ZTE, Control ZTE2S

$\$ 107.74$

$\$ 107.74$

$\$ 131.94$

$\$ 263.88$

Thermostat, Totaline, P374-1100

$\$ 60.00$

$\$ 60.00$

Total

$\$ 6,167.93$

Material

Cost 


\section{Appendix G. Field Surveys of Four Cold Climate Houses for Retrofitting}

Table G.1. Diagnostic Checklist for Arlington, MA House.

\begin{tabular}{|c|c|c|c|}
\hline $\begin{array}{l}\text { Measurement/ } \\
\text { Observation }\end{array}$ & Potential Target value & Actual Value & $\begin{array}{l}\text { Potential Retrofit } \\
\text { Action }\end{array}$ \\
\hline Duct leakage & $<10 \%$ of air handler flow & S $8 \% ;$ R $25 \%$ & Seal ducts: aeroseal/tape/mastic \\
\hline Duct insulation & $\begin{array}{l}\text { R6 (RSI 1) to R8 (RSI 1.4) for all ducts } \\
\text { outside conditioned space }\end{array}$ & R4 & Add insulation to ducts \\
\hline Air flows at registers & Compare to ACCA manual J & $\begin{array}{l}\text { Sum of supplies and } \\
\text { returns: } \mathrm{S} \quad 630 ; \mathrm{R} \quad 445 . \\
\text { Return is restricted. }\end{array}$ & Add a second return. \\
\hline Air handler flow & $\begin{array}{l}\text { Cooling: } 1050 \mathrm{cfm} \text { based on nameplate. } \\
\text { Heating: } 1250 \mathrm{cfm} \text { based on nameplate. }\end{array}$ & $927 \mathrm{cfm}$ & $\begin{array}{l}\text { Replace filters, fix duct restrictions, } \\
\text { change fan speed, replace fan with } \\
\text { high efficient unit, add extra returns } \\
\text { in return restricted systems }\end{array}$ \\
\hline Filter Condition & Clean and at least MERV $6^{7}$ & dirty & Replace with MERV 6 or better. \\
\hline Thermostat Setting & $\begin{array}{l}\text { Heating: } 68^{\circ} \mathrm{F} \quad\left(20^{\circ} \mathrm{C}\right) \quad \text { Cooling: } 78^{\circ} \mathrm{F} \\
\left(25^{\circ} \mathrm{C}\right)\end{array}$ & Programmable & None \\
\hline Spot ventilation & $\begin{array}{l}50 \mathrm{cfm} \text { each bathroom } \\
100 \mathrm{cfm} \text { each kitchen }\end{array}$ & $\begin{array}{l}\text { Up bath } 111 \mathrm{cfm} \text {; down } \\
\text { bath } 32 \mathrm{cfm} \text {; kitchen } 246 \\
\text { cfm }\end{array}$ & None \\
\hline $\begin{array}{l}\text { Spot Ventilation fan } \\
\text { power consumption }\end{array}$ & $\begin{array}{l}2.5 \mathrm{cfm} / \mathrm{W}(1.2 \mathrm{~L} / \mathrm{s} / \mathrm{W}) . \text { Look up in HVI } \\
\text { directory (www.hvi.org) }\end{array}$ & $\begin{array}{l}\text { Up bath } 5.7 \mathrm{cfm} / \mathrm{W} \text {; down } \\
\text { bath } 1.8 \mathrm{cfm} / \mathrm{W} \text {; kitchen } \\
1.7 \mathrm{cfm} / \mathrm{W}\end{array}$ & $\begin{array}{l}\text { Increase cfm output of kitchen and } \\
\text { down bath by removing restriction in } \\
\text { ductwork if possible. }\end{array}$ \\
\hline Equipment capacity & Manual S & 3 tons on nameplate & None \\
\hline Refrigerant charge & Use superheat or subcooling tests & $\begin{array}{l}\text { N/A due to outdoor } \\
\text { temperature }\end{array}$ & Retest on another day. \\
\hline $\begin{array}{l}\text { Age and Condition of } \\
\text { HVAC system }\end{array}$ & $\begin{array}{l}\text { Clean and undamaged. } \\
\text { Determine system age. }\end{array}$ & $\begin{array}{l}\text { OK condition. Age } 7 \\
\text { years. }\end{array}$ & None \\
\hline $\begin{array}{l}\text { Location of HVAC } \\
\text { system equipment and } \\
\text { ducts }\end{array}$ & Inside conditioned space & Basement & $\begin{array}{l}\text { Seal and insulates duct locations to } \\
\text { make them more like conditioned } \\
\text { space, or move system location. }\end{array}$ \\
\hline Window $\mathrm{A} / \mathrm{C}$ units & EnergyStar compliant & None & None \\
\hline Multiple systems/zoning & $\begin{array}{l}\text { System and controls in good working order } \\
\text { and providing good comfort for occupants }\end{array}$ & None & None \\
\hline Envelope leakage & Normalized Leakage Area reduction of 0.35 & ELA: 244 in2; NLA 1.27 & $\begin{array}{l}\text { Airseal plumbing penetrations, attic } \\
\text { chases, top plates, and other } \\
\text { unintentional openings. }\end{array}$ \\
\hline Moisture testing & No moisture problems & None & None \\
\hline House insulation & $\begin{array}{l}\text { Ceiling: R-30 (RSI 5.3) minimum, R-49 (RSI } \\
\text { 8.6) in cold/severe cold climate. Floor over } \\
\text { crawlspace:R- } 25 \text { (RSI 4.4). Basement walls: } \\
\text { R10 (RSI 1.8), Basement Floor or slab usually } \\
\text { depends on local codes. Walls: Cavity should } \\
\text { be completely filled with insulation. }\end{array}$ & $\begin{array}{l}\text { Attic: } 9 \text { inches fiberglass } \\
(\mathrm{R} 30) \text {. Walls: R-14. } \\
\text { Basement ceiling half } \\
\text { insulated with } 6 \text { inches } \\
\text { fiberglass (R 19) }\end{array}$ & $\begin{array}{l}\text { Add at least 6" cellulose or fiberglass } \\
\text { insulation to attic to bring it up to } \mathrm{R} \\
49 \text {. Remove insulation from } \\
\text { basement ceiling, and insulate } \\
\text { basement walls to R } 10 \text {. }\end{array}$ \\
\hline Windows & $\begin{array}{l}\text { Double-glazed, low-e. Shaded in cooling } \\
\text { dominant climates }\end{array}$ & Double glazed vinyl. & None \\
\hline Window shading & Located on south and/or west facing windows & Trees shade the south side & None \\
\hline Solar radiation control & $\begin{array}{l}\text { Radiant barrier in attic, low absorptivity roof } \\
\text { coatings }\end{array}$ & None & $\begin{array}{l}\text { Add reflective paint to roof and/or } \\
\text { sunshades for windows. }\end{array}$ \\
\hline $\begin{array}{l}\text { Wall, floor and ceiling } \\
\text { construction }\end{array}$ & Space for ducts/ vents/ insulation & Attic has plenty of space. & Add insulation in attic. \\
\hline $\begin{array}{l}\text { Occupant survey } \\
\text { Ask occupants to report } \\
\text { problems }\end{array}$ & No problems & $\begin{array}{l}\text { Upstairs hotter than } \\
\text { downstairs when heating. } \\
\text { Downstairs bath hot, } \\
\text { kitchen cold. Furnace } \\
\text { short cycling. }\end{array}$ & $\begin{array}{l}\text { Add zoned system to condition first } \\
\text { and second floor independently. } \\
\text { Duct sealing for dust being drawn in } \\
\text { through return. Possibly replace } \\
\text { windows. }\end{array}$ \\
\hline
\end{tabular}

${ }^{7}$ MERV is an industry standard rating system for air filters, it stands for Minimum Efficiency Report Value determined using ASHRAE Standard 52.2 
Table G.2. Diagnostic Checklist for Marlborough, MA House.

\begin{tabular}{|c|c|c|c|}
\hline $\begin{array}{l}\text { Measurement } \\
\text { / Observation }\end{array}$ & $\begin{array}{l}\text { Potential Target } \\
\text { value }\end{array}$ & Actual Value & Potential Retrofit Action \\
\hline Duct leakage & $<10 \%$ of air handler flow & $\begin{array}{l}\text { Two systems: S1 } 36 \% ; \mathrm{R} 1 \\
13 \% \text { S2 } 31 \% \text { R2 } 37 \%\end{array}$ & Seal ducts in both systems: aeroseal/tape/mastic \\
\hline Duct insulation & $\begin{array}{l}\text { R6 (RSI 1) to R8 (RSI 1.4) for all } \\
\text { ducts outside conditioned space }\end{array}$ & R 4 & Add insulation to ducts \\
\hline Air flows at registers & Compare to ACCA manual J & $\begin{array}{l}\text { Sum of supplies and returns: } \\
\text { S1 410; R1 143; S2 571, R2 } \\
278 \text {. }\end{array}$ & Increase return size in both systems. \\
\hline Air handler flow & $\begin{array}{l}\text { Cooling: System 1:700 cfm; } \\
\text { System 2: nameplate not legible. } \\
\text { Heating: System 1:938 cfm; } \\
\text { System 2: } 1250 \mathrm{cfm} .\end{array}$ & $\begin{array}{l}\text { System 1: } 515 \mathrm{cfm} \\
\text { System 2: } 791 \mathrm{cfm}\end{array}$ & $\begin{array}{l}\text { Replace filters, fix return duct restriction in } \\
\text { both systems. Add a second return in system } 2 \text {, } \\
\text { remove two supplies and return from system } 2 \\
\text { (upstairs bedroom) and add to system } 1 . \\
\text { Change return in } 1^{\text {st }} \text { floor bath into a supply. }\end{array}$ \\
\hline Filter Condition & Clean and at least MERV 6 & Dirty filter & $\begin{array}{l}\text { Replace with MERV } 6 \text { or better. Build filter } \\
\text { slots for both systems. }\end{array}$ \\
\hline Thermostat Setting & $\begin{array}{l}\text { Heating: } 68^{\circ} \mathrm{F}\left(20^{\circ} \mathrm{C}\right) \text { Cooling: } \\
78^{\circ} \mathrm{F}\left(25^{\circ} \mathrm{C}\right)\end{array}$ & Programmable & None \\
\hline Spot ventilation & $\begin{array}{l}50 \mathrm{cfm} \text { each bathroom } \\
100 \mathrm{cfm} \text { each kitchen }\end{array}$ & $\begin{array}{l}\text { Bathrooms: } 64 \mathrm{cfm} ; 79 \mathrm{cfm} \text {; } \\
49 \mathrm{cfm} \text {. Kitchen N/A. }\end{array}$ & None \\
\hline $\begin{array}{l}\text { Spot Ventilation fan } \\
\text { power consumption }\end{array}$ & $\begin{array}{l}2.5 \mathrm{cfm} / \mathrm{W}(1.2 \mathrm{~L} / \mathrm{s} / \mathrm{W}) . \text { Look up } \\
\text { in HVI directory (www.hvi.org) }\end{array}$ & $\mathrm{N} / \mathrm{A}$ & None \\
\hline Equipment capacity & Manual S & 2 tons on system 1 nameplate. & None \\
\hline Refrigerant charge & Use superheat or subcooling tests & $\begin{array}{l}\text { System 1: Actual } / 6 \text { Target } / 23 \\
\text { Airflow is too low for test to } \\
\text { be accurate. System 2: } \\
\text { temperature too cold outside } \\
\text { to do test. }\end{array}$ & Correct airflow and retest systems. \\
\hline $\begin{array}{l}\text { Age and Condition of } \\
\text { HVAC system }\end{array}$ & $\begin{array}{l}\text { Clean and undamaged. } \\
\text { Determine system age. }\end{array}$ & $\begin{array}{l}\text { Both systems probably } 19 \\
\text { years old. Fair condition. }\end{array}$ & Replace systems. \\
\hline $\begin{array}{l}\text { Location of HVAC } \\
\text { system equipment and } \\
\text { ducts }\end{array}$ & Inside conditioned space & $\begin{array}{l}\text { System 1: Attic } \\
\text { System 2: Basement. }\end{array}$ & $\begin{array}{l}\text { Airseal basement to bring it inside conditioned } \\
\text { space. }\end{array}$ \\
\hline Window $\mathrm{A} / \mathrm{C}$ units & EnergyStar compliant & None & None \\
\hline $\begin{array}{l}\text { Multiple } \\
\text { systems/zoning }\end{array}$ & $\begin{array}{l}\text { System and controls in good } \\
\text { working order and providing good } \\
\text { comfort for occupants }\end{array}$ & $\begin{array}{l}\text { Two systems; one } \\
\text { upstairs, the other } \\
\text { downstairs.. }\end{array}$ & None \\
\hline Envelope leakage & $\begin{array}{l}\text { Normalized Leakage } \\
\text { reduction of } 0.35\end{array}$ & ELA: 261 in2; NLA 0.74 & $\begin{array}{l}\text { Airseal plumbing penetrations, attic chases, top } \\
\text { plates, and other unintentional openings. }\end{array}$ \\
\hline Moisture testing & No moisture problems & $\begin{array}{l}\text { Standing water in backyard. } \\
\text { Evidence of water intrusion in } \\
\text { basement. }\end{array}$ & Correct drainage problem. \\
\hline House insulation & $\begin{array}{l}\text { Ceiling: R-30 (RSI 5.3) minimum, } \\
\text { R-49 (RSI 8.6) in cold/severe cold } \\
\text { climate. Floor over crawlspace:R- } \\
25 \text { (RSI 4.4). Basement walls: R10 } \\
\text { (RSI 1.8), Basement Floor or slab } \\
\text { usually depends on local codes. } \\
\text { Walls: Cavity should be completely } \\
\text { filled with insulation. }\end{array}$ & $\begin{array}{l}\text { Attic: } 9 \text { inches fiberglass }(\mathrm{R} \\
\text { 30). Walls: R-11. Basement } \\
\text { ceiling 6" fiberglass: R-19 }\end{array}$ & $\begin{array}{l}\text { Add } 6 " \text { cellulose or fiberglass insulation to } \\
\text { attic. Remove basement ceiling insulation. } \\
\text { Insulate basement walls to R-10. }\end{array}$ \\
\hline Windows & $\begin{array}{l}\text { Double-glazed, low-e. Shaded in } \\
\text { cooling dominant climates }\end{array}$ & Double glazed vinyl. & None \\
\hline Window shading & $\begin{array}{l}\text { Located on south and/or west } \\
\text { facing windows }\end{array}$ & Minimal & Add shading to south and west windows. \\
\hline Solar radiation control & $\begin{array}{l}\text { Radiant barrier in attic, low } \\
\text { absorptivity roof coatings }\end{array}$ & None & $\begin{array}{l}\text { Add reflective paint to roof and/or sunshades } \\
\text { for windows. }\end{array}$ \\
\hline $\begin{array}{l}\text { Wall, floor and ceiling } \\
\text { construction }\end{array}$ & Space for ducts/vents/ insulation & $\begin{array}{l}\text { Attic and basement have } \\
\text { space. }\end{array}$ & Add insulation in attic. \\
\hline $\begin{array}{l}\text { Occupant survey } \\
\text { Ask occupants to } \\
\text { report problems }\end{array}$ & No problems & $\begin{array}{l}\text { Far bedroom is poorly } \\
\text { conditioned. System } 1 \text { fan is } \\
\text { noisy. }\end{array}$ & $\begin{array}{l}\text { Change bedroom ducts from system } 2 \text { to system } \\
\text { 1. Add additional return ducts in both systems. }\end{array}$ \\
\hline
\end{tabular}


Table G.1. Diagnostic Checklist for Northfield, MN House.

\begin{tabular}{|c|c|c|c|}
\hline $\begin{array}{l}\text { Measurement/ } \\
\text { Observation }\end{array}$ & Potential Target value & Actual Value & $\begin{array}{l}\text { Potential Retrofit } \\
\text { Action }\end{array}$ \\
\hline Duct leakage & $<10 \%$ of air handler flow & S 17\%; R 43\% & Seal ducts: aeroseal/tape/mastic \\
\hline Duct insulation & $\begin{array}{l}\text { R6 (RSI 1) to R8 (RSI 1.4) for all ducts } \\
\text { outside conditioned space }\end{array}$ & R 0 & Add insulation to ducts \\
\hline Air flows at registers & Compare to ACCA manual J & $\begin{array}{l}\text { Sum of supplies and } \\
\text { returns: S } 778 ; \mathrm{R} 461 \text {. }\end{array}$ & \\
\hline Air handler flow & $\begin{array}{l}\text { Cooling: } 660 \mathrm{cfm} \text { based on nameplate. } \\
\text { Heating: } 1250 \mathrm{cfm} \text { based on nameplate. }\end{array}$ & $1017 \mathrm{cfm}$ & $\begin{array}{l}\text { Replace filters, fix duct restrictions, } \\
\text { change fan speed, replace fan with } \\
\text { high efficient unit, add extra returns } \\
\text { in return restricted systems }\end{array}$ \\
\hline Filter Condition & Clean and at least MERV 6 & Clean & Replace with MERV 6 or better. \\
\hline Thermostat Setting & Heating: $68^{\circ} \mathrm{F}\left(20^{\circ} \mathrm{C}\right)$ Cooling: $78^{\circ} \mathrm{F}\left(25^{\circ} \mathrm{C}\right)$ & Non-programmable & Install programmable thermostat \\
\hline Spot ventilation & $\begin{array}{l}50 \mathrm{cfm} \text { each bathroom } \\
100 \mathrm{cfm} \text { each kitchen }\end{array}$ & Down bath $61 \mathrm{cfm}$ & None \\
\hline $\begin{array}{l}\text { Spot Ventilation fan } \\
\text { power consumption }\end{array}$ & $\begin{array}{l}2.5 \mathrm{cfm} / \mathrm{W}(1.2 \mathrm{~L} / \mathrm{s} / \mathrm{W}) \text {. Look up in HVI } \\
\text { directory (www.hvi.org) }\end{array}$ & N/A & None \\
\hline Equipment capacity & Manual S & $\begin{array}{l}\text { Nameplate: } 2 \text { tons; } 100 \\
\text { kBtuh }\end{array}$ & None \\
\hline Refrigerant charge & Use superheat or subcooling tests & N/A & Retest on another day. \\
\hline $\begin{array}{l}\text { Age and Condition of } \\
\text { HVAC system }\end{array}$ & $\begin{array}{l}\text { Clean and undamaged. } \\
\text { Determine system age. }\end{array}$ & $\begin{array}{l}\text { Good condition. Age } 3 \\
\text { years. }\end{array}$ & None \\
\hline $\begin{array}{l}\text { Location of } \begin{array}{r}\text { HVAC } \\
\text { system equipment and } \\
\text { ducts }\end{array} \\
\text { duts }\end{array}$ & Inside conditioned space & Basement & $\begin{array}{l}\text { Seal and insulates duct locations to } \\
\text { make them more like conditioned } \\
\text { space, or move system location. }\end{array}$ \\
\hline Window $\mathrm{A} / \mathrm{C}$ units & EnergyStar compliant & None & None \\
\hline Multiple systems/zoning & $\begin{array}{l}\text { System and controls in good working order } \\
\text { and providing good comfort for occupants }\end{array}$ & None & None \\
\hline Envelope leakage & Normalized Leakage Area reduction of 0.35 & ELA: 100 in 2 ; NLA 0.34 & None \\
\hline Moisture testing & No moisture problems & $\begin{array}{l}\text { Basement carpet has } \\
\text { moldy odor, } \\
\text { condensation in upstairs } \\
\text { bath fan duct. }\end{array}$ & $\begin{array}{l}\text { Add insulation to bath fan duct, and } \\
\text { run it on an angle instead of straight } \\
\text { up. Address basement moisture } \\
\text { issues. }\end{array}$ \\
\hline House insulation & $\begin{array}{l}\text { Ceiling: R-30 (RSI 5.3) minimum, R-49 (RSI } \\
\text { 8.6) in cold/severe cold climate. Floor over } \\
\text { crawlspace:R- } 25 \text { (RSI 4.4). Basement walls: } \\
\text { R10 (RSI 1.8), Basement Floor or slab usually } \\
\text { depends on local codes. Walls: Cavity should be } \\
\text { completely filled with insulation. }\end{array}$ & $\begin{array}{l}\text { Attic: } 7 \text { inches fiberglass } \\
(\mathrm{R} \mathrm{24).} \mathrm{Walls:} \mathrm{R-11} \mathrm{and} \\
\mathrm{R}-19 . \quad \text { Basement } \\
\text { crawlspace has some } \\
\text { fiberglass. }\end{array}$ & $\begin{array}{l}\text { Add 8" of cellulose or fiberglass } \\
\text { insulation to attic to bring it up to } \mathrm{R} \\
49 \text {. Remove insulation from } \\
\text { basement ceiling, and insulate } \\
\text { basement walls to R } 10 \text {. }\end{array}$ \\
\hline Windows & $\begin{array}{l}\text { Double-glazed, low-e. Shaded in cooling } \\
\text { dominant climates }\end{array}$ & $\begin{array}{l}\text { Double glazed low-e } \\
\text { wood, and some single } \\
\text { glazed. }\end{array}$ & None \\
\hline Window shading & Located on south and/or west facing windows & & None \\
\hline Solar radiation control & $\begin{array}{l}\text { Radiant barrier in attic, low absorptivity roof } \\
\text { coatings }\end{array}$ & None & $\begin{array}{l}\text { Add reflective paint to roof and/or } \\
\text { sunshades for windows. }\end{array}$ \\
\hline $\begin{array}{l}\text { Wall, floor and ceiling } \\
\text { construction }\end{array}$ & Space for ducts/vents/ insulation & Attic has plenty of space. & Add insulation in attic. \\
\hline $\begin{array}{l}\text { Occupant survey } \\
\text { Ask occupants to report } \\
\text { problems }\end{array}$ & No problems & $\begin{array}{l}\text { Rooms above garage } \\
\text { slightly warmer than rest } \\
\text { of house. }\end{array}$ & None \\
\hline
\end{tabular}


Table G.1. Diagnostic Checklist for Plymouth, MN House.

\begin{tabular}{|c|c|c|c|}
\hline $\begin{array}{l}\text { Measurement/ } \\
\text { Observation }\end{array}$ & Potential Target value & Actual Value & $\begin{array}{l}\text { Potential Retrofit } \\
\text { Action }\end{array}$ \\
\hline Duct leakage & $<10 \%$ of air handler flow & S $8 \% ;$ R $25 \%$ & Seal ducts: aeroseal/tape/mastic \\
\hline Duct insulation & $\begin{array}{l}\text { R6 (RSI 1) to R8 (RSI 1.4) for all ducts } \\
\text { outside conditioned space }\end{array}$ & R4 & Add insulation to ducts \\
\hline Air flows at registers & Compare to ACCA manual $\mathrm{J}$ & $\begin{array}{l}\text { Sum of supplies and } \\
\text { returns: S 630; R } 445 . \\
\text { Return is restricted. }\end{array}$ & Add a second return. \\
\hline Air handler flow & $\begin{array}{l}\text { Cooling: } 1050 \mathrm{cfm} \text { based on nameplate. } \\
\text { Heating: } 1250 \mathrm{cfm} \text { based on nameplate. }\end{array}$ & $927 \mathrm{cfm}$ & $\begin{array}{l}\text { Replace filters, fix duct restrictions, } \\
\text { change fan speed, replace fan with } \\
\text { high efficient unit, add extra returns } \\
\text { in return restricted systems }\end{array}$ \\
\hline Filter Condition & Clean and at least MERV 6 & dirty & Replace with MERV 6 or better. \\
\hline Thermostat Setting & $\begin{array}{l}\text { Heating: } 68^{\circ} \mathrm{F} \quad\left(20^{\circ} \mathrm{C}\right) \quad \text { Cooling: } 78^{\circ} \mathrm{F} \\
\left(25^{\circ} \mathrm{C}\right)\end{array}$ & Programmable & None \\
\hline Spot ventilation & $\begin{array}{l}50 \mathrm{cfm} \text { each bathroom } \\
100 \mathrm{cfm} \text { each kitchen }\end{array}$ & $\begin{array}{l}\text { Up bath } 111 \mathrm{cfm} \text {; down } \\
\text { bath } 32 \mathrm{cfm} \text {; kitchen } 246 \\
\text { cfm }\end{array}$ & None \\
\hline $\begin{array}{l}\text { Spot Ventilation fan } \\
\text { power consumption }\end{array}$ & $\begin{array}{l}2.5 \mathrm{cfm} / \mathrm{W}(1.2 \mathrm{~L} / \mathrm{s} / \mathrm{W}) . \text { Look up in HVI } \\
\text { directory (www.hvi.org) }\end{array}$ & $\begin{array}{l}\text { Up bath } 5.7 \mathrm{cfm} / \mathrm{W} \text {; down } \\
\text { bath } 1.8 \mathrm{cfm} / \mathrm{W} ; \text { kitchen } \\
1.7 \mathrm{cfm} / \mathrm{W}\end{array}$ & $\begin{array}{l}\text { Increase cfm output of kitchen and } \\
\text { down bath by removing restriction in } \\
\text { ductwork if possible. }\end{array}$ \\
\hline Equipment capacity & Manual S & 3 tons on nameplate & None \\
\hline Refrigerant charge & Use superheat or subcooling tests & $\begin{array}{l}\text { N/A due to outdoor } \\
\text { temperature }\end{array}$ & Retest on another day. \\
\hline $\begin{array}{l}\text { Age and Condition of } \\
\text { HVAC system }\end{array}$ & $\begin{array}{l}\text { Clean and undamaged. } \\
\text { Determine system age. }\end{array}$ & $\begin{array}{l}\text { OK condition. Age } 7 \\
\text { years. }\end{array}$ & None \\
\hline $\begin{array}{l}\text { Location of } \begin{array}{l}\text { HVAC } \\
\text { system equipment and } \\
\text { ducts }\end{array} \\
\end{array}$ & Inside conditioned space & Basement & $\begin{array}{l}\text { Seal and insulates duct locations to } \\
\text { make them more like conditioned } \\
\text { space, or move system location. }\end{array}$ \\
\hline Window $\mathrm{A} / \mathrm{C}$ units & EnergyStar compliant & None & None \\
\hline Multiple systems/zoning & $\begin{array}{l}\text { System and controls in good working order } \\
\text { and providing good comfort for occupants }\end{array}$ & None & None \\
\hline Envelope leakage & Normalized Leakage Area reduction of 0.35 & ELA: 244 in2; NLA 1.27 & $\begin{array}{l}\text { Airseal plumbing penetrations, attic } \\
\text { chases, top plates, and other } \\
\text { unintentional openings. }\end{array}$ \\
\hline Moisture testing & No moisture problems & None & None \\
\hline House insulation & $\begin{array}{l}\text { Ceiling: R-30 (RSI 5.3) minimum, R-49 (RSI } \\
\text { 8.6) in cold/severe cold climate. Floor over } \\
\text { crawlspace:R- } 25 \text { (RSI 4.4). Basement walls: } \\
\text { R10 (RSI 1.8), Basement Floor or slab usually } \\
\text { depends on local codes. Walls: Cavity should } \\
\text { be completely filled with insulation. }\end{array}$ & $\begin{array}{l}\text { Attic: } 9 \text { inches fiberglass } \\
(\mathrm{R} 30) \text {. Walls: R-14. } \\
\text { Basement ceiling half } \\
\text { insulated with } 6 \text { inches } \\
\text { fiberglass (R 19) }\end{array}$ & $\begin{array}{l}\text { Add at least } 6 \text { " cellulose or fiberglass } \\
\text { insulation to attic to bring it up to R } \\
49 \text {. Remove insulation from } \\
\text { basement ceiling, and insulate } \\
\text { basement walls to R 10. }\end{array}$ \\
\hline Windows & $\begin{array}{l}\text { Double-glazed, low-e. Shaded in cooling } \\
\text { dominant climates }\end{array}$ & Double glazed vinyl. & None \\
\hline Window shading & Located on south and/or west facing windows & Trees shade the south side & None \\
\hline Solar radiation control & $\begin{array}{l}\text { Radiant barrier in attic, low absorptivity roof } \\
\text { coatings }\end{array}$ & None & $\begin{array}{l}\text { Add reflective paint to roof and/or } \\
\text { sunshades for windows. }\end{array}$ \\
\hline $\begin{array}{l}\text { Wall, floor and ceiling } \\
\text { construction }\end{array}$ & Space for ducts/ vents/ insulation & Attic has plenty of space. & Add insulation in attic. \\
\hline $\begin{array}{l}\text { Occupant survey } \\
\text { Ask occupants to report } \\
\text { problems }\end{array}$ & No problems & $\begin{array}{l}\text { Upstairs hotter than } \\
\text { downstairs when heating. } \\
\text { Downstairs bath hot, } \\
\text { kitchen cold. Furnace } \\
\text { short cycling. }\end{array}$ & $\begin{array}{l}\text { Add zoned system to condition first } \\
\text { and second floor independently. } \\
\text { Duct sealing for dust being drawn in } \\
\text { through return. Possibly replace } \\
\text { windows. }\end{array}$ \\
\hline
\end{tabular}

